UCRL-ID- 115510

\title{
The CONVEX Liner Add-On to the DIAMOND-FORTUNE Event
}

\author{
Francois E. Heuze, LLNL \\ Robert P. Swift, LANL \\ Leslie R. Hill, SNLA \\ William H. Barrett, SNLA
}

November 15, 1993

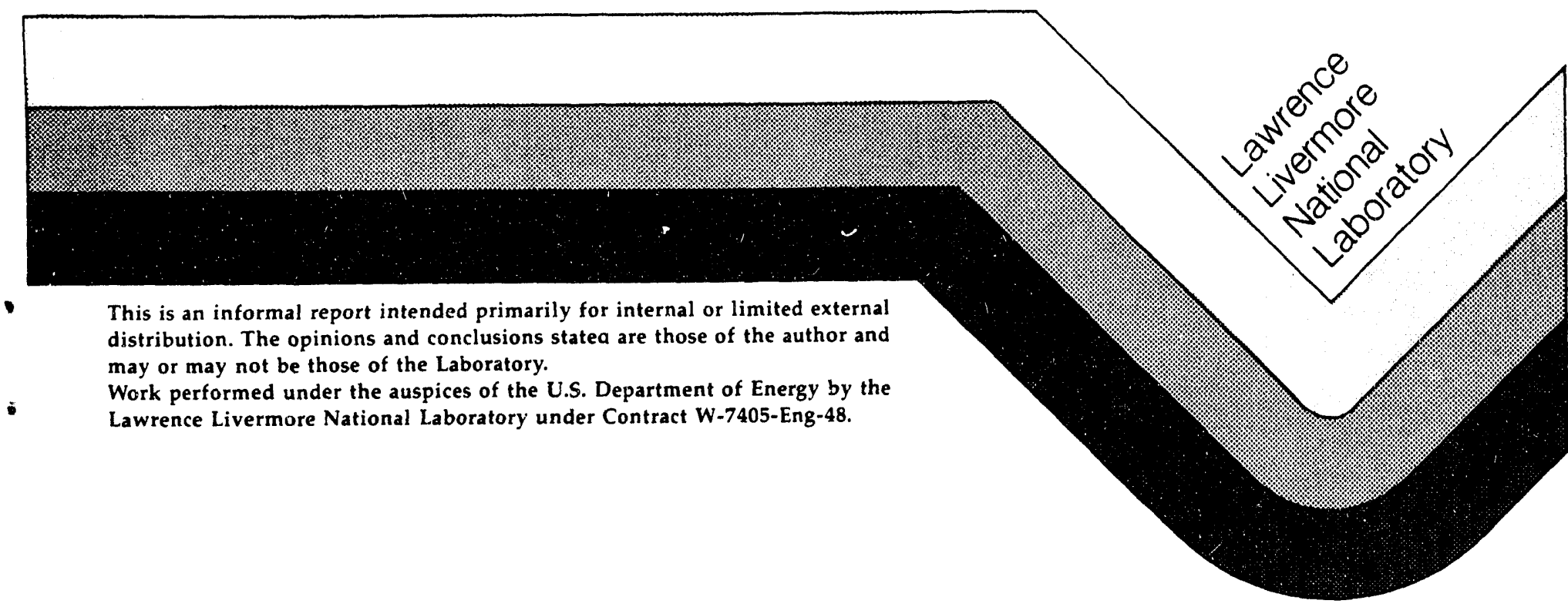




\section{DISCLAIMER}

This document was prepared as an account of work sponsored by an agency of the United States Government. Neither the United States Government nor the University of Califoraia nor any of their employees, makes any warranty, express or implied, or assumes any legal liability or responsibility for the accuracy, completeness, or usefulness of any information, apparatus, produch, or process disclosed, or represents that its use would not infringe privately owned rights. Reference herein to any specific commercial products, process, or service by trade name, trademark, manufacturer, or otherwise, does not necessarily constitute or imply its endorsement, recommendation, or favoring by the United States Government or the University of California. The views and opinions of authors expressed herein do not necessarily state or reflect those of the United States Government or the University of California, and shall not be used for advertising or product endorsement purposes.

This report has been reproduced directly from the best available copy.

Available to DOE and DOE contractors from the Office of Scientific and Technical Information

P.O. Box 62, Oak Ridge, TN 37831

Prices available from (615) 576-8401, FTS 626-8401

Available to the public from the

National Technical Information Service

US. Department of Commerce 5285 Port Royal Rd. Springfield, VA 22161 


\section{TABLE OF CONTENTS}

PAGE

SUMMARY

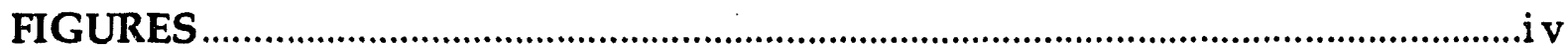

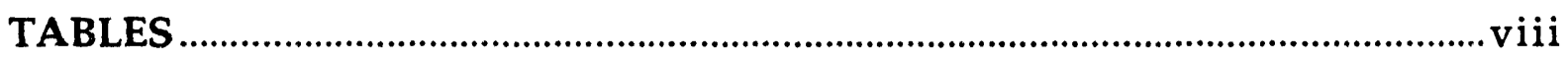

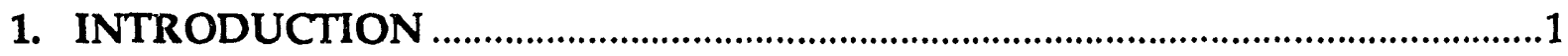

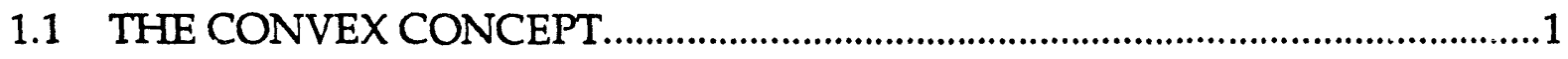

1.2 RELATED WORK PRECEDING DIAMOND FORTUNE .....................................

1.3 THE DIAMOND FORTUNE LINER ADD-ON ……............................................

2. SITE CHARACTERIZATION.................................................................................9

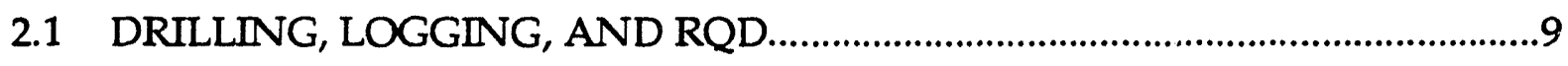

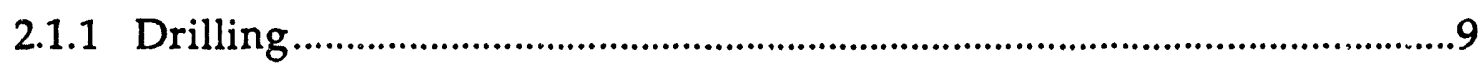

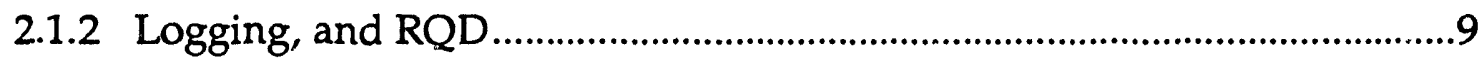

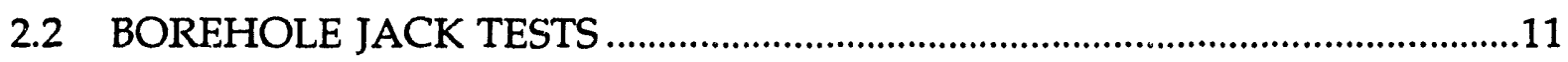

2.3 PROPERTIES OF ROCK MATERIALS............................................................

2.3.1 Physical Properties.................................................................................16

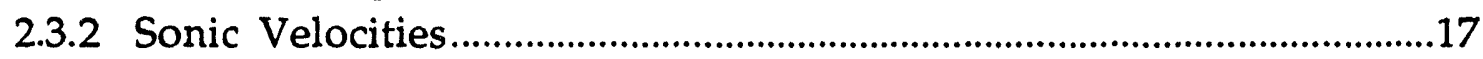

2.3.3 Triaxial Compressive Tests................................................................17

2.3.4 Summary ..............................................................................................19

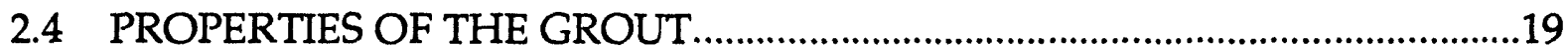

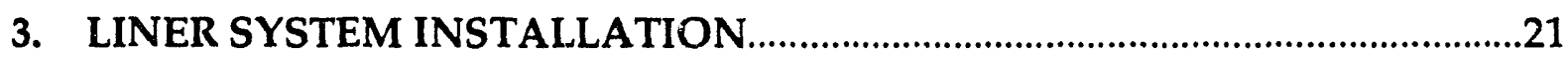

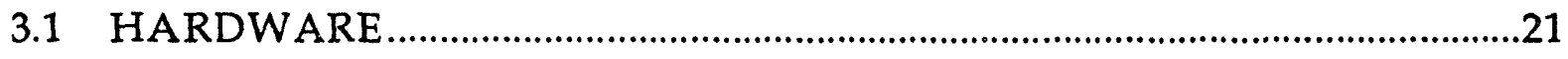

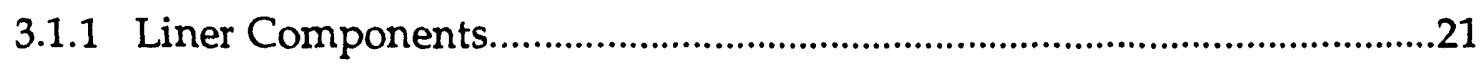

3.1.2 Steel Properties.........................................................................................23

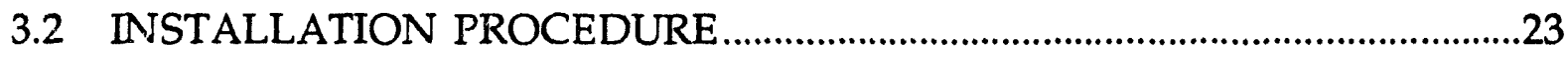

4. INSTRUMENTATION AND DATA. ACQUISITION ……...............................32

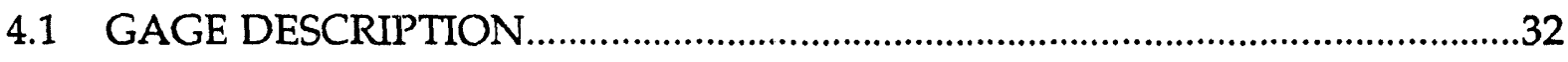

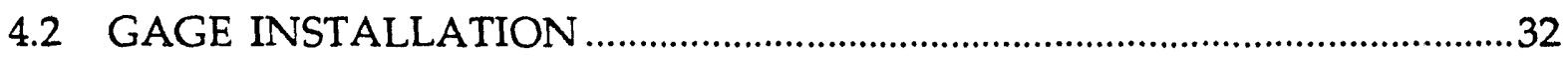




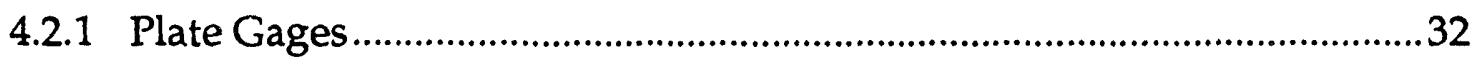

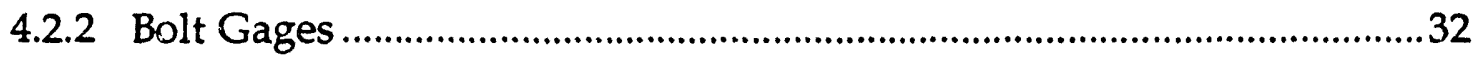

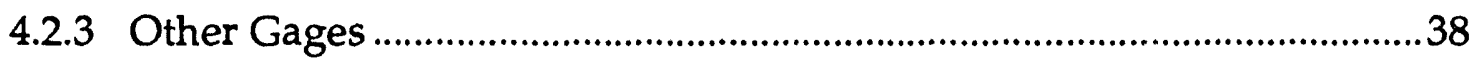

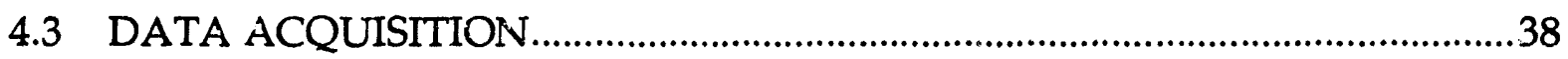

4.3.1 SANDUS.

4.3.2 Installed Gage System Summary............................................................39

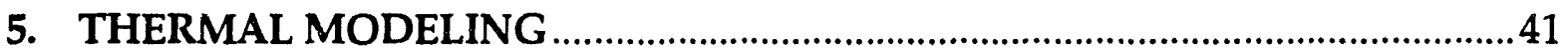

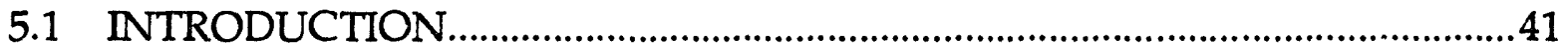

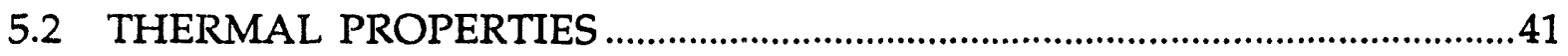

5.3 RESULTS OF THERMAL CALCULATIONS …..................................................43

6. MECHANICAL MODELING ............................................................................

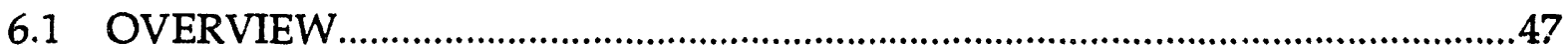

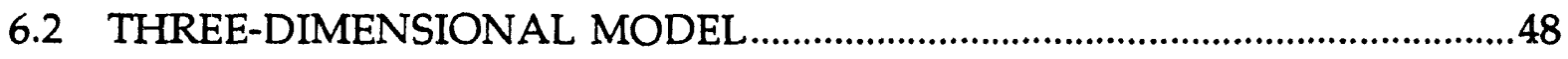

6.3 3-D EQUILIBRIUM CONDITION …………..................................................51

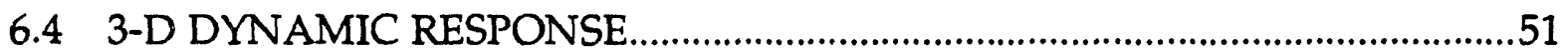

6.4.1 Effect of Rock Mass Stiffness...................................................................54

6.4.2 Effect of Corner Bolt/Grout Interface Properties......................................57

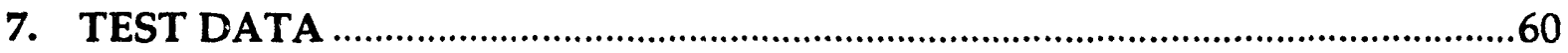

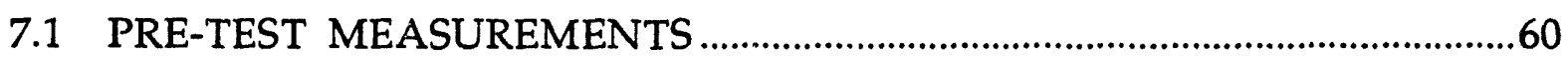

7.2 TEST DATA

7.2.1 Loading on Rock ...............................................................................63

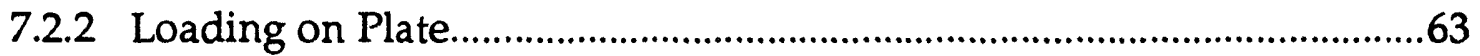

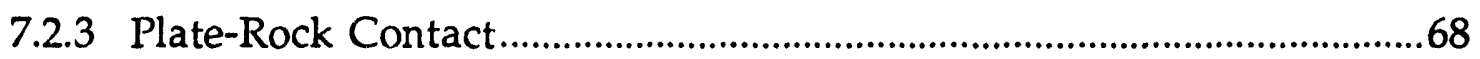

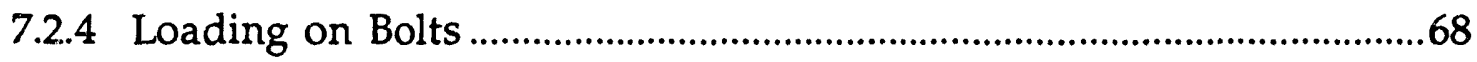

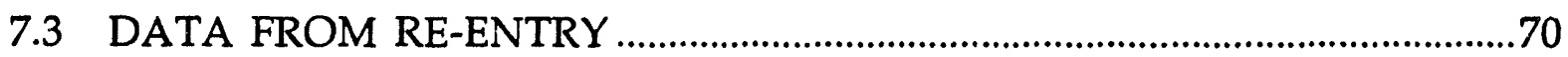

8. COMPARISON OF TEST DATA AND CALCULATIONS …………………......72

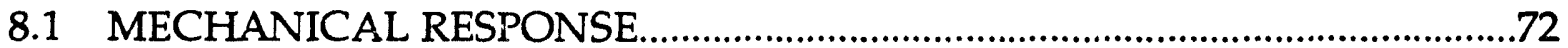

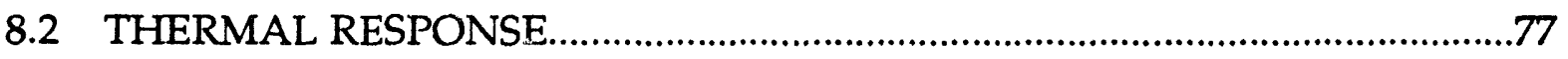

9. SUMMARY AND CONCLUSIONS..................................................................78

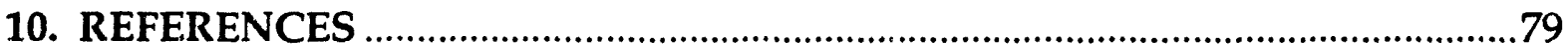

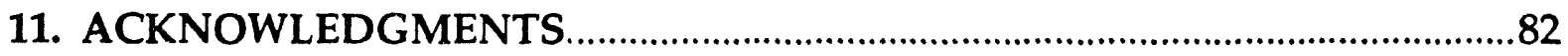




\section{SUMMARY}

This report describes the execution of the CONVEX Liner Add-On to the DIAMOND FORTUNE low-yield cavity test of the Defense Nuclear Agency (DNA). It is cross-referenced as DNA POR-7472.

CONVEX stands for COntained Nuclear Vessel EXperiment. It is a joint concept of 3 Department of Energy Laboratories (LANL, LLNL, SNL) and the DNA. It concerns the design of underground chambers where repeated low-yield nuclear explosions could be conducted.

The approach proposed by the first author in the early 1980's was to engineer a steel-lined rock cavern where the steel liner would be pre-stressed against the rock by tendons and/or bolts. These would daylight in tunnels surrounding the main cavity. From there, they could be initially tensioned and retensioned, if needed, after each test.

The CONVEX Liner Add-On to DIAMOND FORTUNE consisted of anchoring a $1.4-\mathrm{m}$ square, $2.5-\mathrm{cm}$ thick steel plate to the wall of the cavity, using a $5.08-\mathrm{cm}$ diameter center bolt, and four $2.54-\mathrm{cm}$ diameter corner bolts. The bolts daylighted in a drift surrounding the gallery, and separated from it by a 9-m thick rock pillar.

The liner plate, the bolts, and the rock pillar were equipped with 23 gages to describe the thermal and mechanical response of the system during pretensioning, during the dynamic loading phase, and post-test. Particular emphasis was given to obtaining the response both ', on loading and during the rebound of the system, in order to determine whether the plate ever separated from the rock. So, the main operational objectives of this project were to acquire response data of the system under nuclear loading and to ascertain the status of contact between the steel plate and the rock, as shown by toadstool data and bolt tension data.

The instrumentation and data acquisition system performed extremely well. Data were recorded during the dynamic phase; plate temperature was monitored for several hours after the test; and the remaining tension was obtained for several bolts more than three months after the test, upon re-entry in the runaround drift. The test results indicated that the operational objectives had been meet and that the concept of a steel-lined rock cavity could provide for reusable test beds for repeated low yield nuclear events. 


\section{FIGURES}

Figure 1-1. Schematic diagram of the Dynamic Bolt Test, Pre-MILLYARD, after [7].

Figure 1-2. Cavity-side anchorage system and stemming process, Pre-MILLYARD. .4

Figure 1-3. Tensioning and load measurement system in anchorage alcove, Pre-MILLYARD.

Figure 1-4 Geometric lay-out of CONVEX liner add-on........................................6

Figure 1-5. DIAMOND FORTUNE lay-out and location of liner add-on...........6

Figure 1-6: DIAMOND FORTUNE cavity under excavation...................................7

Figure 1-7: DIAMOND FORTUNE run-around drift showing the bedding of the tuff..................................................................................

Figure 2-1. Layout of the CONVEX liner drill-holes..............................................10

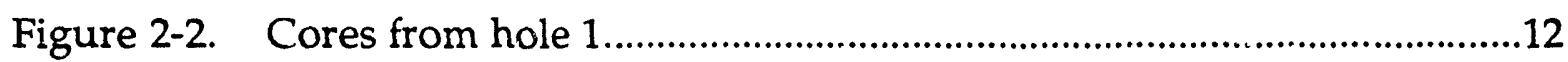

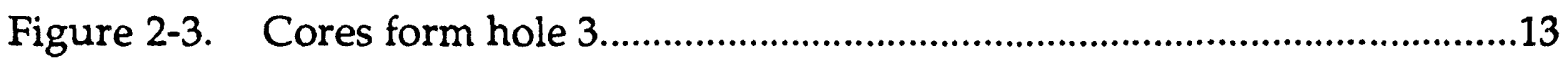

Figure 2-4. RQD for hole 1. .............................................................................

Figure 2-5. RQD for hole 3. ............................................................................

Figure 2-6. In-situ modulus vs RQD, in hole 3 …...............................................15

Figure 2-7. Axial stress-strain records for specimens from hole 3, in triaxial compression. ......................................................................................18

Figure 3-1: Verticai cross-section of the liner-bolt system. ………………….......22

Figure 3-2: Liner plate area smoothed out, and drill holes. ..................................25

Figure 3-3: Drift side; casing grouted in center hole. ...............................................25

Figure 3-4: Cavity side, center bolt coupling, and toadstools. ...............................26

Figure 3-5: Drift side; sulfaset pads and center bolt cables. ..................................26

Figure 3-6: Cavity side, prior to installing the plate. …….......................................27

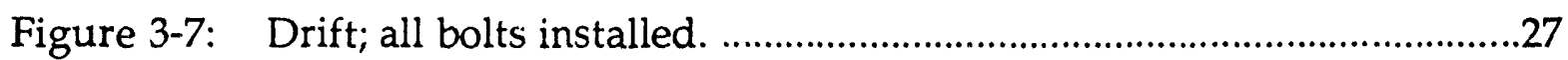




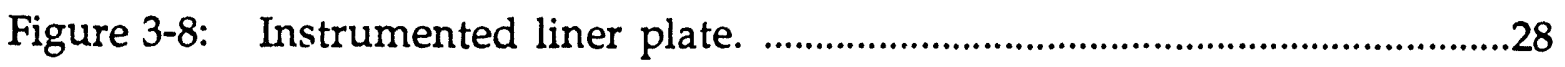

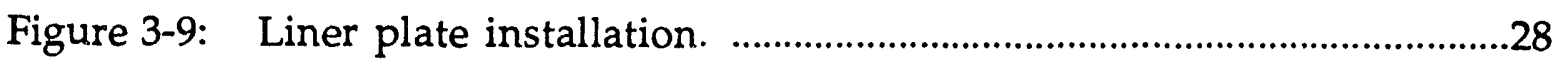

Figure 3-10: Microseismic monitoring during bolt tensioning. ….......................29

Figure 3-11: Tranducers, holders, and signal conditioners. ..................................29

Figure 3-12: Drift; bolt pattern and cables. .................................................................30

Figure 3-13: Drift; jack and load cell for center bolt tensioning. ............................30

Figure 3-14: Cavity; CONVEX liner ready for testing. ...........................................31

Figure 3-15: Drift; system ready prior to grouting of drift. .......................................31

Figure 4-1: Design of plate strain enclosures, top view............................................34

Figure 4-2: Design of plate strain enclosures, side view. .......................................34

Figure 4-3: Close-up of strain gage stations on plate...........................................35

Figure 4-4: Back of instrumented CONVEX liner plate...........................................35

Figure 4-5: Design of gage mounting on center bolt................................................36

Figure 4-6: Close-up of gage station on center bolt................................................37

Figure 4-7: Instrumented center bolt; drift-side bolt thread is protected

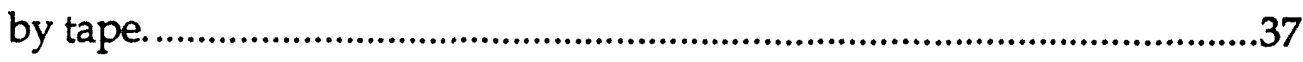

Figure 5-1. Geometries for thermal analyses.........................................................42

Figure 5-2: Calculated temperature histories, bare rock cavity. ...........................44

Figure 5-3: Calculated temperature histories, steel lined cavity. .........................45

Figure 5-4: Calculated temperature histories, center bolt. .....................................45

Figure 5-5: Calculated temperature histories, corner bolt on axis. .....................46

Figure 5-6: Calculated temperature histories, corner bolt at bolt/grout contact

Figure 6-1: Complete model for 3-d mechanical analysis. Note the double curvature of the cavity wall.....................................................................49

Figure 6-2: Details of model for plate, bolts, and grout model...........................49

Figure 6-3: Pressure loading function on liner plate..........................................50

Figure 6-4: Compressibility for rock and grout, used in calculations.................50 
Figure 6-5 Strength behavior for rock and grout, used in calculations...........50

Figure 6-6: Calculated equilibrium vertical-strain on back of plate, caused by $325 \mathrm{MPa}$ tension in bolts................................................................52

Figure 6-7: Calculated equilibrium horizontal-strain on back of plate, caused by $325 \mathrm{MPa}$ tension in bolts.

Figure 6-8: Calculated equilibrium displacement into cavity wall, on back of plate, caused by $325 \mathrm{MPa}$ tension in bolts.

Figure 6-9: Axial-stress distribution in centerbolt and plate components from equilibrium calculation.

Figure 6-10: Calculated axial stress response in centerbolt (stiff model, solid curve; soft model, dash curve).

Figure 6-11: Calculated axial stress response in cornerbolt (stiff model, solid curve; soft model, dash curve).

Figure 6-12: Calculated axial stress response in rock behind the plate (stiff model, solid curve; soft model, dash curve).

Figure 6-13: Calculated axial stress response midway in the rock pillar (stiff model, solid curve; soft model, dash curve).

Figure 6-14: Calculated axial acceleration response in rock pillar (stiff model, solid curve; soft model, dash curve).

Figure 6-15: Calculated horizontal plate stress at mid-height half way to edge, stiff model (rear surface, solid curve; front surface, dash curve)...58

Figure 6-16: Comparison of calculated horizontal stress at mid height half way to edge in plate for soft model (rear surface, solid curve; front surface, dash curve).

Figure 6-17: Calculated axial stress in cornerbolt comparing effect of bolt-grout interface conditions for soft model. (constrained with friction coefficient 1.9, solid curve; unconstrained, dash curve). .59

Figure 7-1: Sketch of strain gage location and nomenclature..............................61

Figure 7-2: Accelerometer record, nearly 4-m into rock pillar............................63

Figure 7-3: Floor FCP (7010) record to 30 milliseconds..........................................64 
Figure 7-4: FCP 7010 data expanded for the first $2 \mathrm{~ms}$..........................................64

Figure 7-5: Accelerometer record on back side of liner plate................................65

Figure 7-6: Plate vertical strain history, right side (7100)......................................66

Figure 7-7: Plate horizontal strain history, right side (7105)................................66

Figure 7-8: Plate vertical strain history, left side (7110)........................................67

Figure 7-9: Plate horizontal strain history, left side (7115)...................................67

Figure 7-10: Toadstool records behind liner plate....................................................68

Figure 7-11: Four center bolt strain gage records; note the remarkable consistency ..........................................................................................69

Figure 7-12: Upper left corner bolt strain gage record at mid-pillar.....................70

Figure 7-13: 3 corner bolt load washer pigtails excavated-out and read at reentry...................................................................................................71

Figure 7-14: Re-entry to drift side of liner add-on..................................................71

Figure 8-1: Comparison of measured axial strain in centerbolt at $x=4.89 \mathrm{~m}$ (solid curve), with calculation (dash curve).......................................73

Figure 8-2: Comparison of measured axial strain in cornerbolt at $x=4.3 \mathrm{~m}$ (solid curve), with calculation (dash curve)......................................73

Figure 8-3: Comparison of measured horizontal strain on back of plate (solid curve), with calculation (dash curve).........................................75

Figure 8-4: Comparison of measured vertical strain on back of plate (solid curve), with calculation (dash curve).........................................75

Figure 8-5: Comparison of normal stress behind plate measured by toadstool (solid curve), with calculation (dash curve)........................................76

Figure 8-6: Comparison of measured acceleration on back of plate (solid curve), with calculation (dash curve)..................................................76

Figure 8-7: Comparison of measured acceleration in pillar (solid curve), with calculation (dash curve).................................................................76

Figure 8-8: Comparison of measured and predicted temperature on the back of the plate. 


\section{TABLES}

Table 1-1: Instrumentation for CONVEX Liner Add-On ......................................

Table 2-1: In-situ modulus from NX-jack tests as a function of hydraulic line

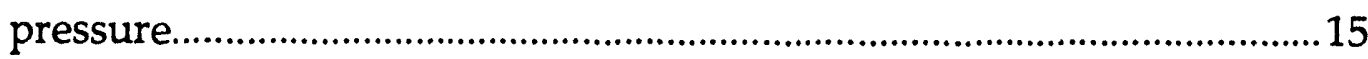

Table 2-2: Physical characteristics of samples from hole 3......................................16

Table 2-3: Sonic velocities, as a function of confining pressure, for cores from

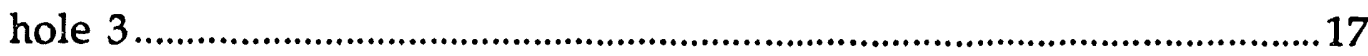

Table 2-4: Mechanical properties of samples from hole 3........................................19

Table 2-5: Summary of properties measured for the HLNCC grout used

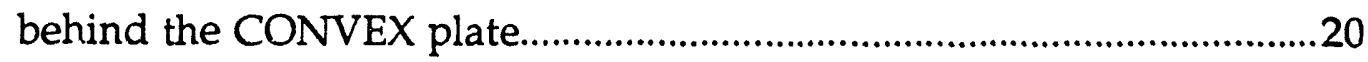

Table 3-1: Mechanical properties of CONVEX liner steels, after $[15,16] \ldots \ldots \ldots \ldots \ldots . . .23$

Table 4-1: Detailed information on the CONVEX Liner Add-On gages..................33

Table 4-2: Summary of characteristics for the installed gage system ......................40

Table 5-1: Properties of steel, grout, and rock for thermal calculations .................43

Table 6-1: Best estimate of elastic and plastic material properties for

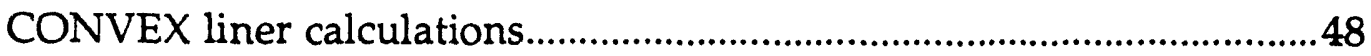

Table7-1: D-day, and D-1 static strain gage measurements from SANDUS ........60

Table 7-2: Tension loads (lbs.) in 3 corner bolt load washers, drift side, read by hand (orientation: facing plate in cavity)....................................62

Table 7-3: Temperature time-history on back of liner plate.......................................65 


\section{SECTION 1}

\section{INTRODUCTION}

\subsection{THE CONVEX CONCEPT}

CONVEX stands for COntained Nuclear Vessel EXperiment. The basic idea is to provide reusable underground cavities in which a series of low-yield (up to 300 tons) nuclear explosions can be performed for the purpose of research in weapons physics and non-weapon high-energy physics. CONVEX is a joint effort of the three DOE weapons laboratories (LANL, LLNL, SNL), and the Defense Nuclear Agency (DNA). This effort is coordinated by the Joint CONVEX Coordination Group (JCCG) made up of representatives of each of the four institutions.

An excellent overview of the subject was provided by the CONVEX Topical conference held in February, 1991, at Los Alamos, NM. A non-exhaustive list of the topics covered in that meeting includes:

- requirements for weapons research

- other, non-defense, application areas

- past efforts on containment vessels

- nuclear devices (sources)

- structural design: chamber, liner, closures, ...

- shock mitigation on the wall

- operations: robotics, recertification, ...

- waste handling, activation, decontamination

- related foreign efforts.

This report describes the CONVEX Liner Experiment, an add-on to the DIAMOND FORTUNE nuclear event. That add-on was designed to test how a steel liner-and-bolts system would respond to the severe thermal and mechanical environment inside a nuclear cavity in rock. DIAMOND FORTUNE, a low-yield cavity shot of the Defense Nuclear Agency, was executed in April 1992. 


\subsection{RELATED WORK PRECEDING DIAMOND FORTUNE}

In the early 1980's, LLNL worked on HEDEF (High-Energy Density Experimental Facility), a precursor of CONVEX [1-4]. As part of the study it was concluded that a steel-lined rock cavity would offer better containment than a free-standing steel vessel [3]. In addition, the steel liner would be pre-stressed against the rock by bolts which would daylight in tunnels adjacent to the cavity [4]. This additional feature had previously been proposed for large cavities in Rainier Mesa at the Nevada Test Site (NTS) [5]. The bolts could be re-iensioned from the surrounding galleries. Also, water could be used to mitigate blast effects on the cavity wall [6]. The dynamic response of a rock-liner-bolt system could be studied through numerical modeling; but, clearly, some field data are essential to evaluate the merits of the concept, and to validate the numerical models for future use in assessing various designs.

A first field test was performed as an add-on to the October, 1984 high-explosive pre-MILLYARD test of the DNA [7, 8]; $134 \mathrm{~kg}$ (300 lbs) of nitromethane were detonated in a 2.74- $\mathrm{m}$ (9-ft) radius hemispherical chamber in tuff in the U12n tunnel complex of Rainier Mesa. Four 2.5-cm diameter (1-in) bolts were installed on the cavity wall in a diamond pattern. They were about $6-\mathrm{m}$ long $(20-\mathrm{ft})$ and daylighted in an adjacent alcove (Figures 1-1 to 1-3). Each bolt had two longitudinal strain gages, and a load cell to measure bolt tension at the anchorage location in the outside alcove. The bolts were tensioned to between 100 and $150 \mathrm{kN}$ (22,000 to $33,000 \mathrm{psi})$. The bolt holes were grouted, but a grease bondbreaker was used over the center 4-m length of bolts to free them from the grout. The partial grouting was used, in conjunction with seal rings, to contain explosion gases.

Strain gage and load cell measurements, and post-test visual inspections all concurred to indicate that the bolts had remained in tension, and that the bearing plates remained firmly against their grout backing and the rock $[7,8]$. This early work was a stepping stone for the add-on to DIAMOND FORTUNE. 


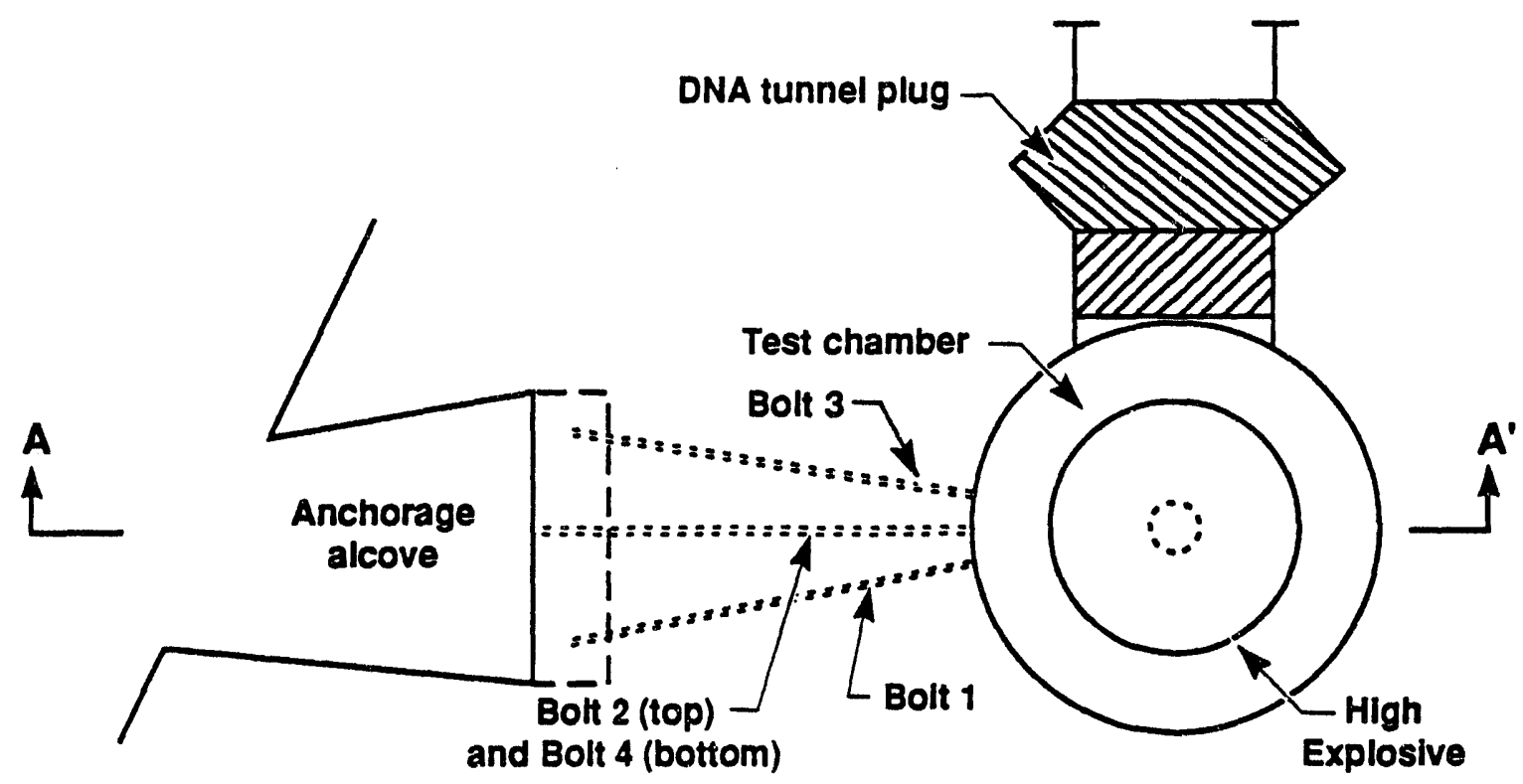

Plan Vlew

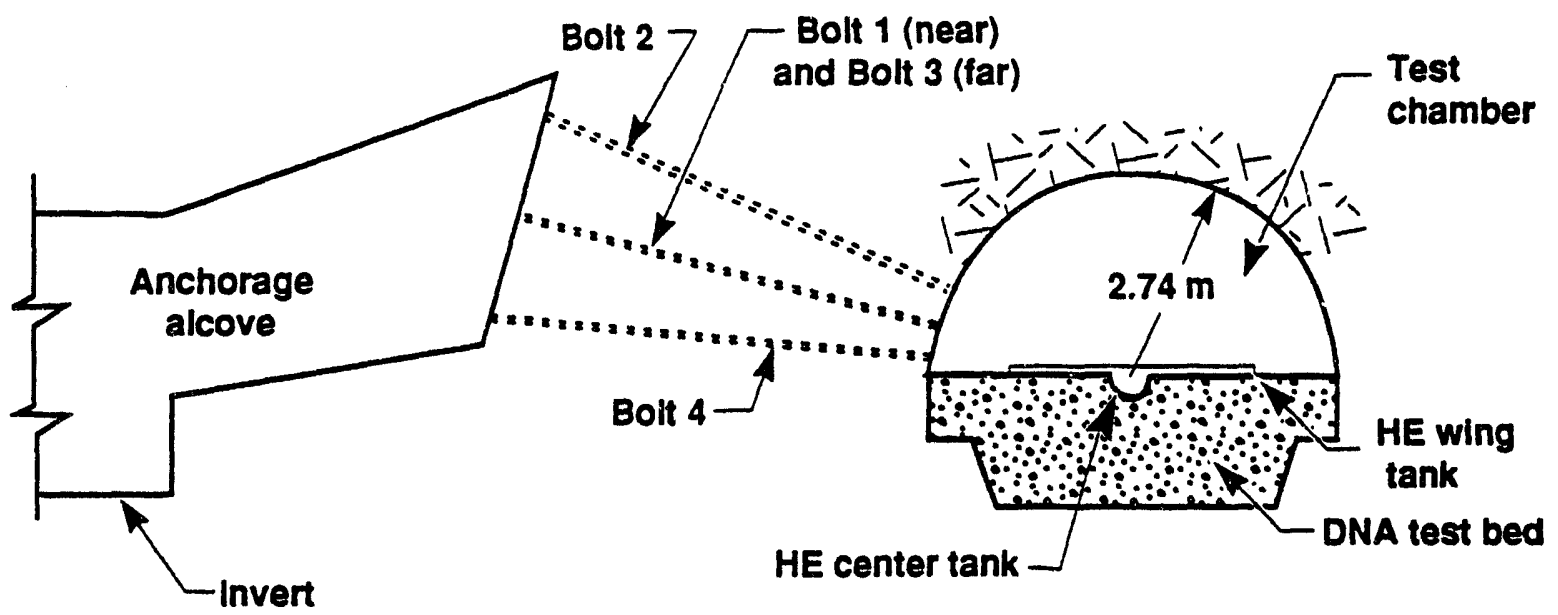

Elevation AA'

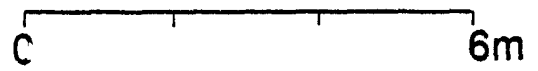

Figure 1-1. Schematic diagram of the Dynamic Bolt Test add-on to Pre-MILLYARD, after [7]. 


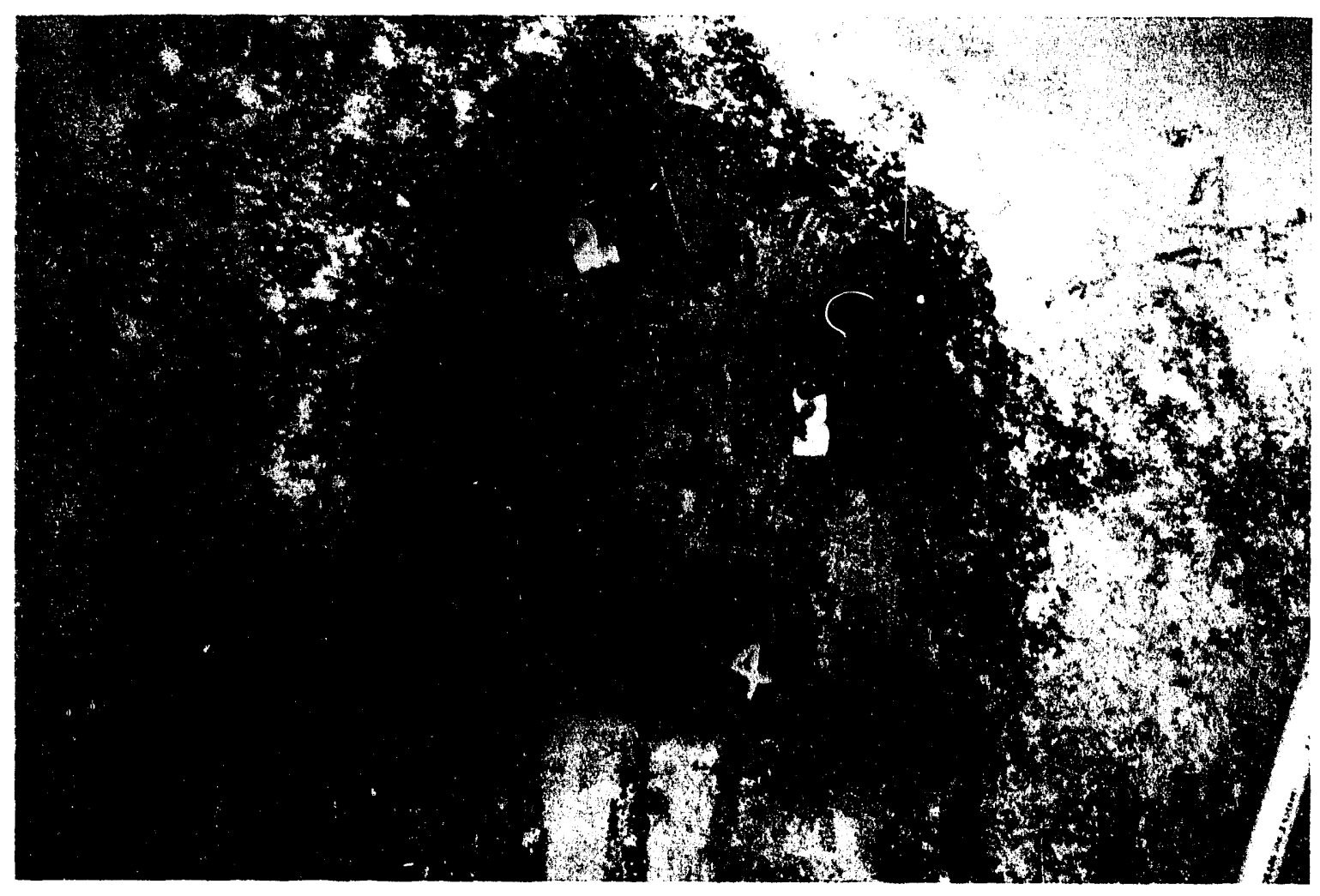

Figure 1-2: Cavity-side bolt system in pre-MILLYARD; after [7].

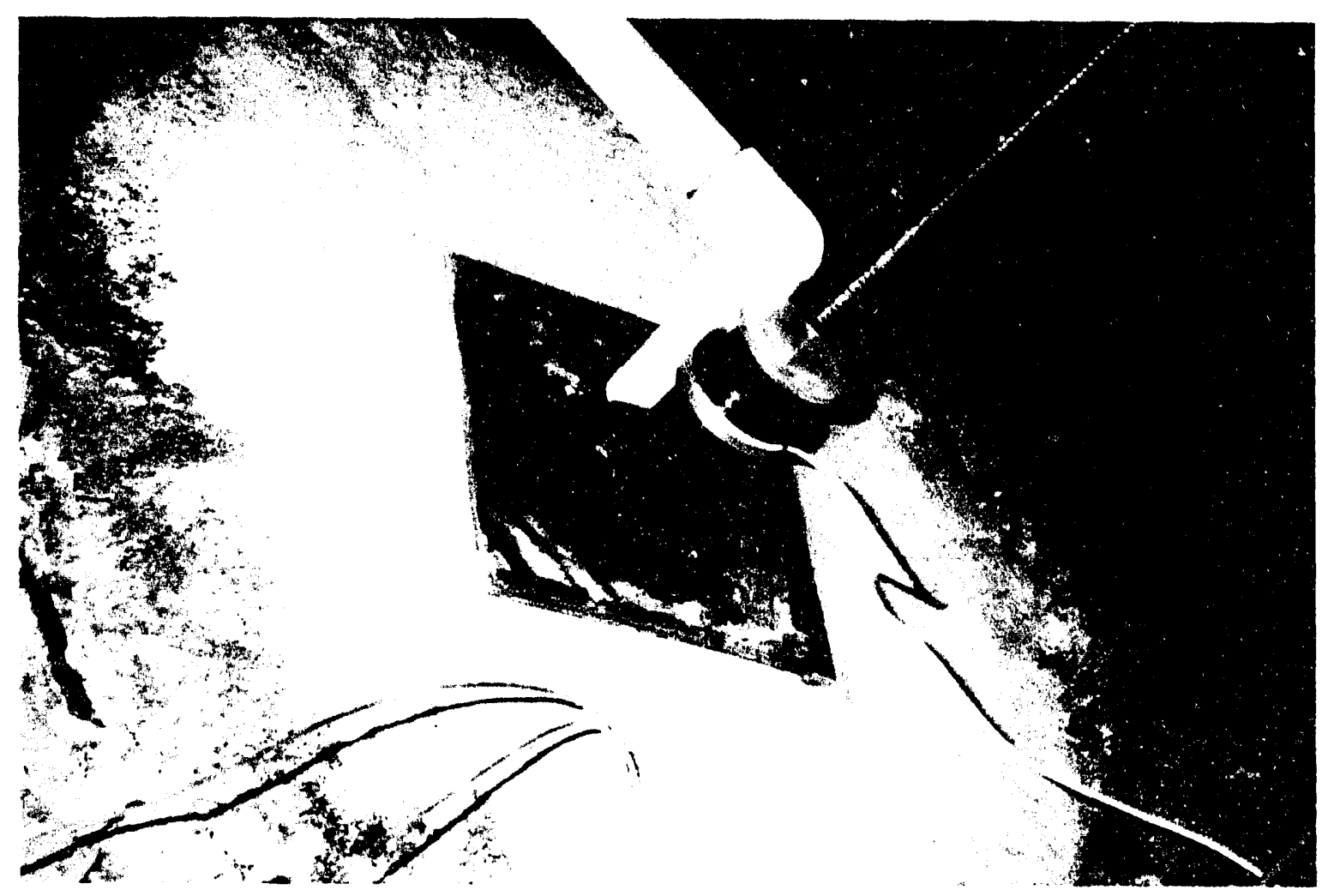

Figure 1-3: Tensioning and load measurement system in anchorage alcove, pre-MILLYARD; after [7]. 


\subsection{THE DIAMOND FORTUNE LINER ADD-ON}

The add-on consisted of a square steel plate anchored vertically to the cavity wall by 4 corner bolts and a center bolt, with the bolts day-lighting in an adjacent, "run-around" drift (Figure 1-4). The plate is $1.4 \mathrm{~m}$ (55 in)square, $2.5 \mathrm{~cm}$ ( 1 in) thick, and made of A36 steel. The diameter of the bolts is $2.5 \mathrm{~cm}$ ( 1 in) at the corners, and $5 \mathrm{~cm}(2 \mathrm{in})$ at the center. The bolts are about $9 \mathrm{~m}(30 \mathrm{ft})$ long, and made of 1045 steel. Additional information on the steels is given in Section 3. The location of the add-on is shown in Figure 1-5. The cavity and the runaround drift are shown in Figures 1-6 and 1-7.

A thin layer of grout, about $5-\mathrm{cm}$ thick, was called for between the plate and the rock to provide a smooth bearing surface. After curing of this grout, the bolts would be tensioned to less than $50 \%$ of their yield strength which exceeds 700 MPa $(100,000 \mathrm{psi})$. This initial tension was selected on the basis of preliminary calculations indicating that the bolts would not go into compression during the dynamic loading, if pre-tensioned to that level.

The desirable diagnostics included: strains on the plate and along the bolts, bolt tension, plate acceleration, temperature on the back of the plate, contact pressure between the plate and the rock (i.e. in the grout layer), cavity wall pressure, and acceleration in rock inside the $9 \mathrm{~m}$ pillar separating the cavity and the runaround drift. With the allocation of a maximum of 20 recording channels, the decision was made to adopt the set of diagnostics shown in Table 1-1. In addition, three corner bolt load washers were read by hand. Details on the instruments are given in Section 4.

Table 1-1: Instrumentation for the CONVEX Liner Add-On, on Recording Channels

Press. Accel. Tture. Stress Strain

\begin{tabular}{|c|c|c|c|c|c|c|}
\hline Rock: & $\begin{array}{l}3 \text { Fluid-Coupled Plates (FCP's) } \\
1 \text { Accelerometer }\end{array}$ & $\sqrt{ }$ & $\sqrt{ }$ & & & \\
\hline Plate: & $\begin{array}{l}4 \text { Strain Gages } \\
1 \text { Thermocouple } \\
1 \text { Accelerometer }\end{array}$ & & $\sqrt{ }$ & $\sqrt{ }$ & & $\sqrt{ }$ \\
\hline Plate/rock: & 2 Toadstools & $\sqrt{ }$ & & & & \\
\hline Center bolt: & $\begin{array}{l}4 \text { Strain Gages } \\
1 \text { Load Cell }\end{array}$ & & & & $\sqrt{ }$ & $\sqrt{ }$ \\
\hline Corner bolt (1): & $\begin{array}{l}2 \text { Strain Gages } \\
1 \text { Load Cell }\end{array}$ & & & & $\sqrt{ }$ & $\sqrt{ }$ \\
\hline
\end{tabular}




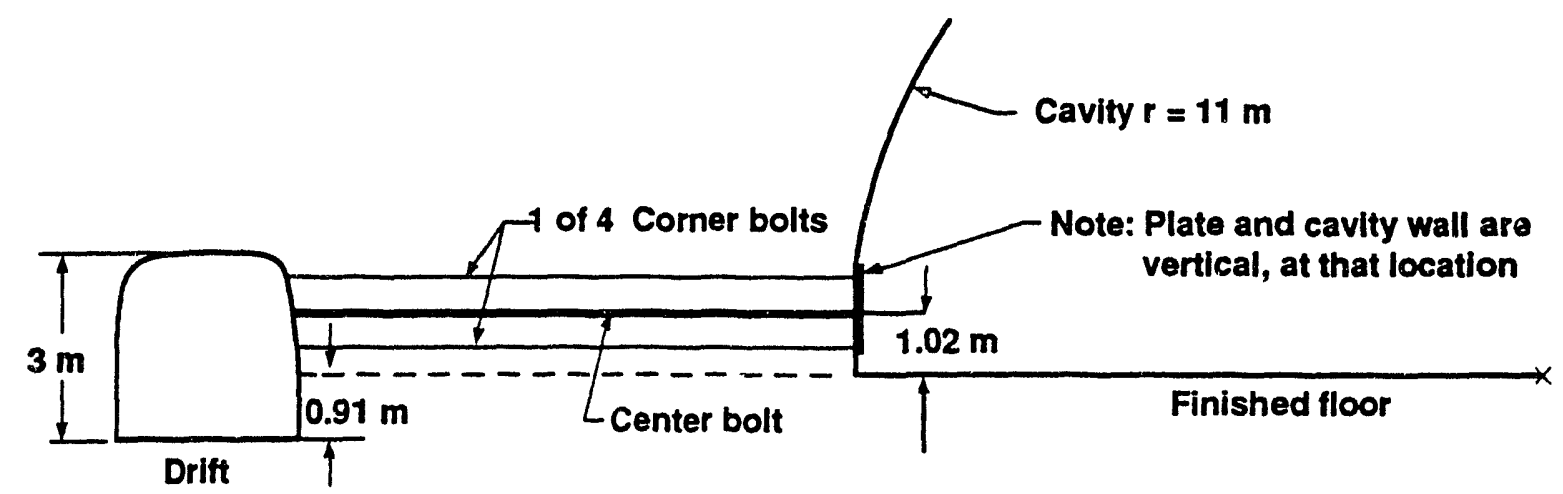

Figure 1-4: Geometric lay-out of CONVEX liner add-on; elevation.

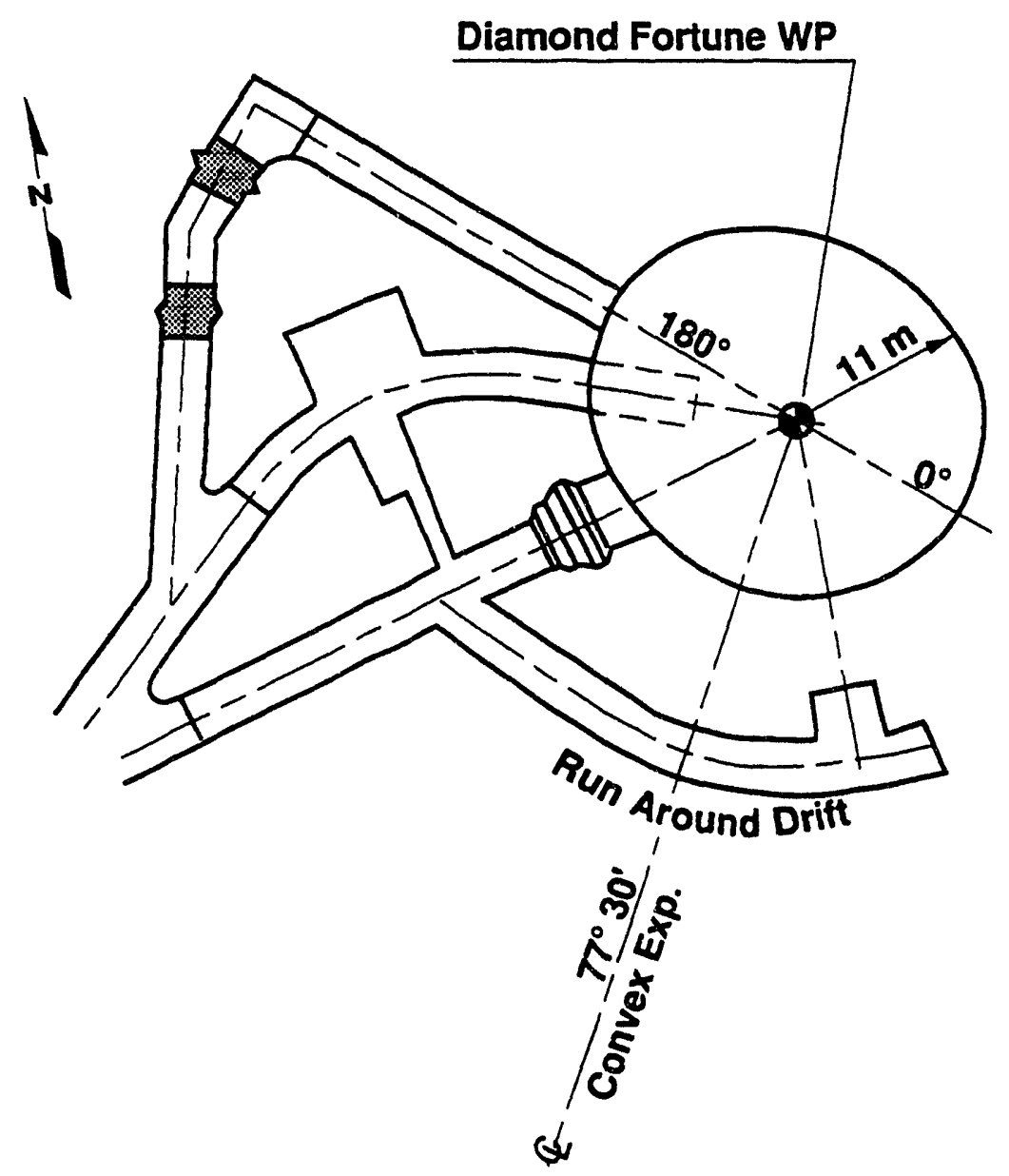

Figure 1-5: DIAMOND FORTUNE lay-out and location of liner add-on. 


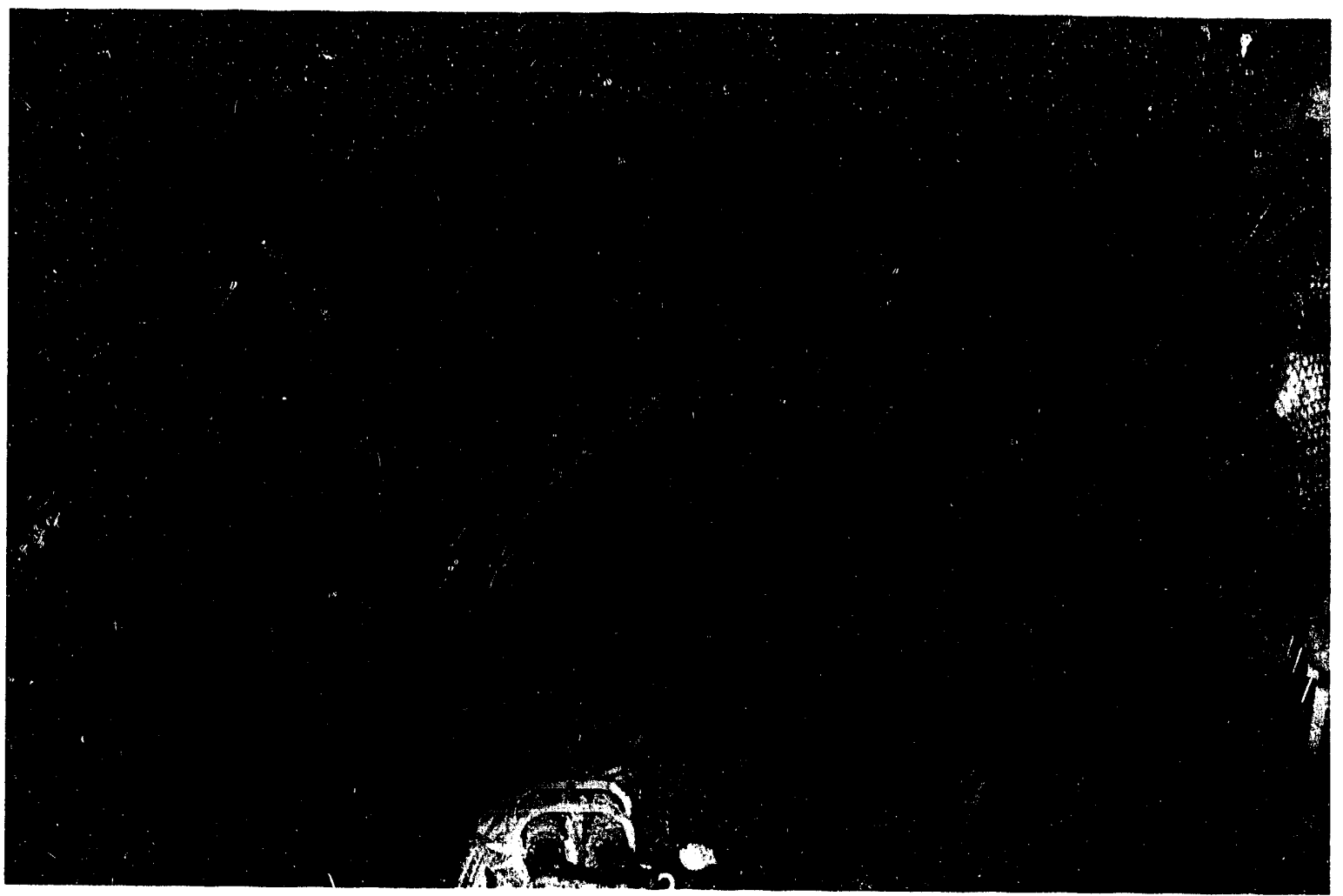

Figure 1-6: DIAMOND FORTUNE cavity under excavation.

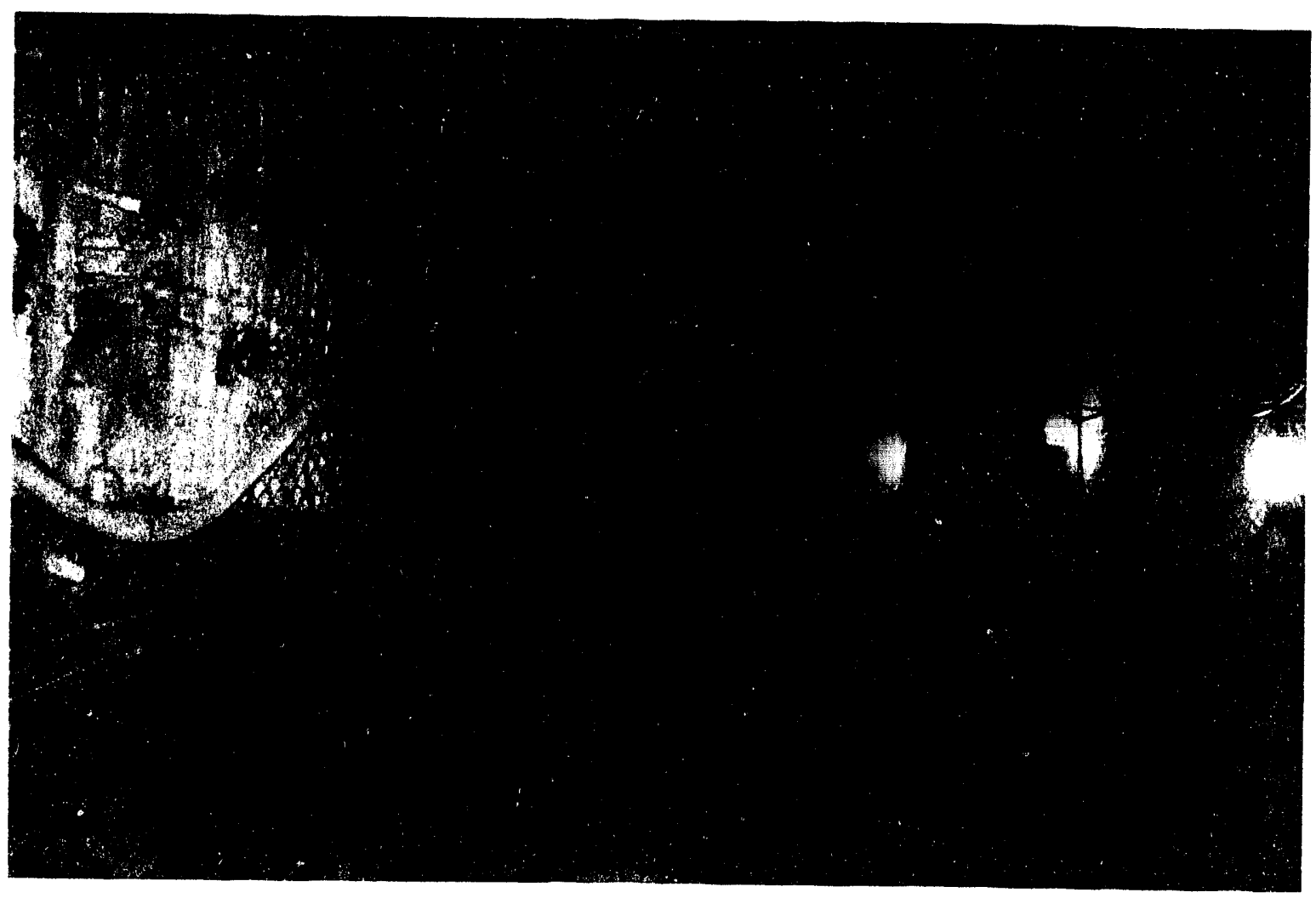

Figure 1-7: DIAMOND FORTUNE run-around drift showing the bedding of the tuff. 
Under an internal explosion, a cavity initially will expand. It will then rebound. In fact, it can go through several cycles of expansion and rebound due to the shock interactions inside the cavity. This has been observed in previous cavicy tests. The rebound motion is the most critical with regard to the potential separation of a cavity liner from its grout/rock backing. Thus it was imperative that the instrumentation operate through one or more expansion-rebound cycles at DIAMOND FORTUNE. For the mechanical response, a target recording time of $80 \mathrm{msec}$ was selected as allowing several such cycles. On the other hand, the thermal response recording was planned for more than $2 \mathrm{hrs}$.

Beside the construction, instrumentation and emplacement of the liner-bolt system, the project included several other major components: site characterization, numerical modeling, and data analysis.

- the site characterization testing provided the material properties required for numerical modeling. The in-situ rock mass stiffness was estimated on the basis of in-situ borehole-jack tests. Wave speed and rock strength were obtained on small cores. Thermal properties were selected from published results for igneous rocks in general, and NTS Rainier Mesa tuffs in particular. The site characterization is described in Section 2.

- the numerical modeling addressed both the mechanical and thermal response of the entire rock-liner-bolt system. Pre-test calculations were designed to guide the choice of instruments, their recording ranges, and duration of recording, to set the tensioning of the bolts, and generally to produce confidence that the concept would work, i.e. the liner system would survive the event and remain operational. The pre-test calculations assumed a mechanical/thermal loading environment based on results of the MILLYARD and MINI JADE cavity-events which were quite similar in cavity geometry and yield to DIAMOND FORTUNE. The post-test calculations were performed with the best estimate of the actual cavity pressure history at the liner plate location. The numerical modeling is described in Sections 5 and 6.

- the test data are provided in Section 7 and are compared to calculated estimates in Section 8.

The project coordination, site characterization and numerical modeling were performed by LLNL. The fielding of the liner-bolts system, its instrumenting, and the data acquisition were performed by SNL. Data analysis was a joint LLNL/Sandia effort, with the additional cooperation of Los Alamos National Laboratory for the definition of the cavity pressure-time history. 


\section{SECTION 2}

\section{SITE CHARACTERIZATION}

\subsection{DRILLING, LOGGING, AND RQD}

\subsubsection{Drilling}

Ten holes were drilled between the cavity and the run-around drift. The as-built layout is shown in Figure 2-1. For convenience, the original dimensions and elevations in feet were retained. Except for hole 2, all were drilled to a nominal NQ size, i.e. $7.58-\mathrm{cm}$ (2.984 in) diameter [9], and were uncased. The cores had an average diameter of $4.49-\mathrm{cm}(1.87 \mathrm{in})$. Hole 2 was drilled to $15.24-\mathrm{cm}(6 \mathrm{in})$ diameter, and a 10.16-cm (4in) OD Sch 40 steel pipe was used to case it. Holes 8, 9, and 10 were reamed to a diameter of $20.3 \sim \mathrm{cm}(8 \mathrm{in})$ for a depth of about $30-\mathrm{cm}$, on the cavity size. The purpose of the holes was as follows:

Hole 1: for instrumentation cables, and for a rock accelerometer located 4-m deep from the cavity

Hole 2: $\quad$ for the center bolt

Hole 3: $\quad$ for instrumentation cables

Hole 4, 5, 6, 7: for corner bolts

Hole 8, 9, 10: for fluid coupled plates (FCP) and their cables.

At the time of the test, all the holes were grouted, except for hole 2, where the casing was capped and grouted to the rock, and filled inside with Vistanex* , around the bolt. Vistanex is an odorless and non-toxir hydrocarbon polymer (polyisobutylene) made by EXXON Chemical Company.

\subsubsection{Logging, and RQD}

For the record, every drill hole was photographed along its entire length with a

\footnotetext{
* Trade names used in this report are provided for completeness.
} 


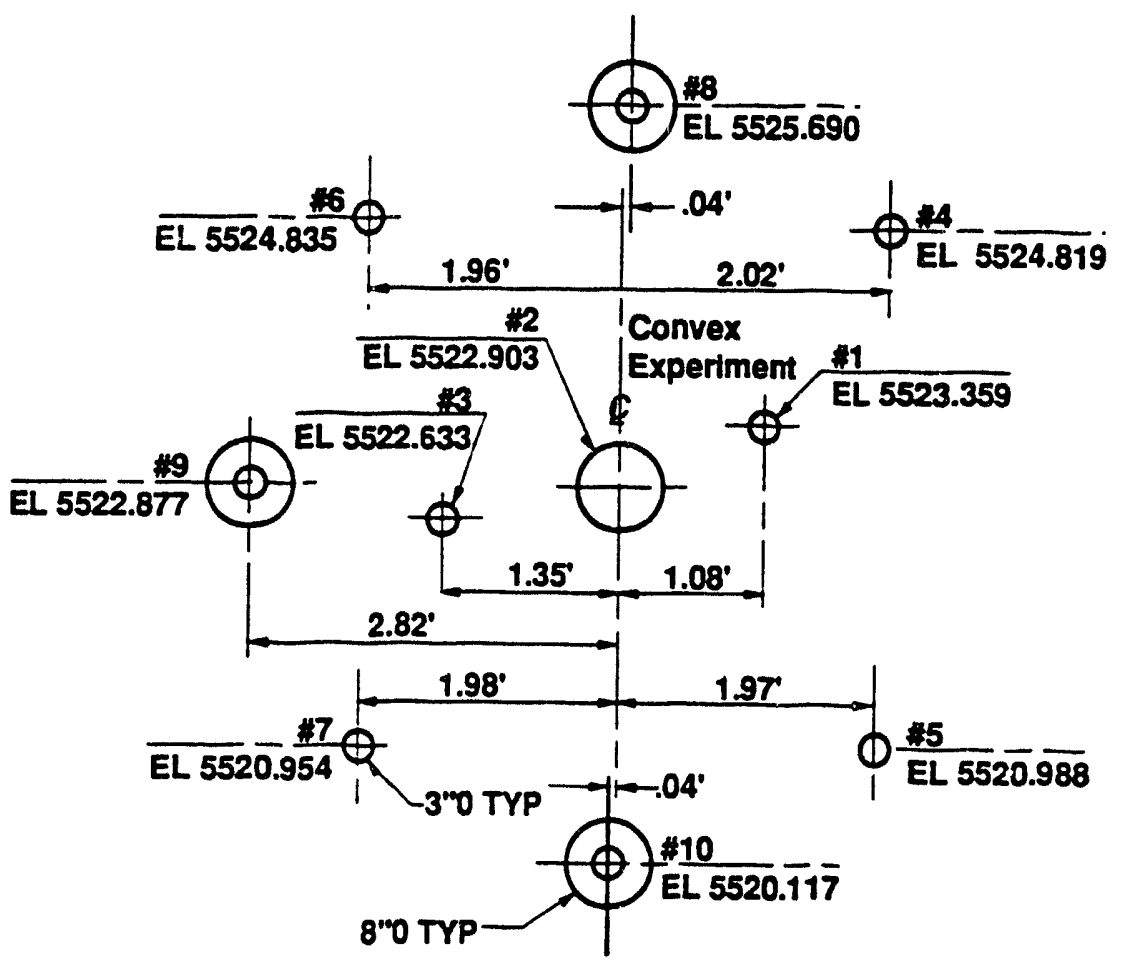

\section{Cavity Side}

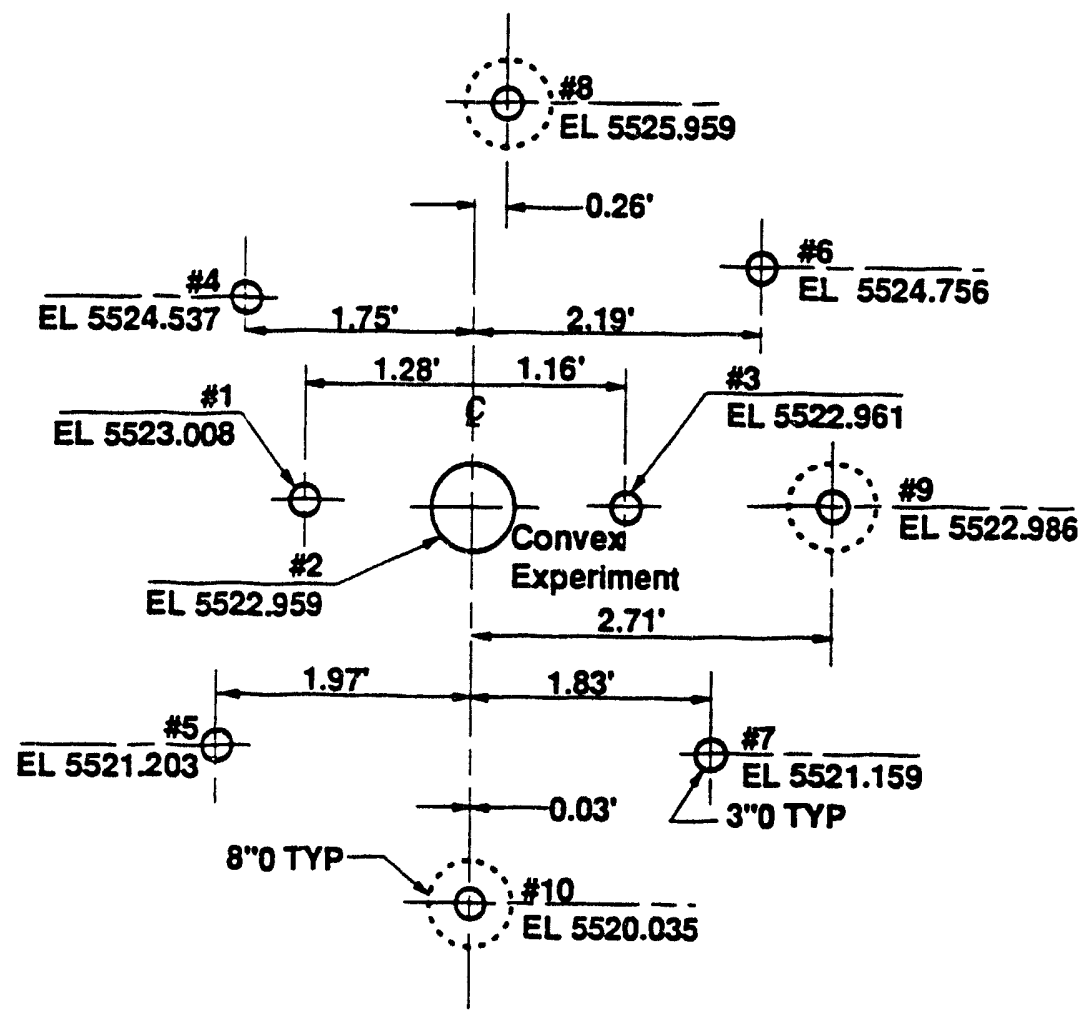

Drift Side

Figure 2-1: Layout of CONVEX liner drill holes. 
video camera. Holes 1 and $3^{*}$ were selected as representative of the add-on location; their cores were logged, photographed, and wax-sealed. They are shown on Figures 2-2 and 2-3. They indicate a sequence of vitric and zeolitized bedded ashfall tuffs.

The Rock Quality Designation, RQD [10], was calculated for both holes, in hole increments of $76-\mathrm{cm}(2.5 \mathrm{ft})$. With a core diameter of $4.49-\mathrm{cm}(1.87 \mathrm{in})$, the minimum length retained for RQD was $10.16-\mathrm{cm}(4 \mathrm{in})$. RQD is shown as a function of location, in Figures 2-4 and 2-5. The data indicate a strong variability of rock quality within the pillar. The mean values over the entire hole length were

\section{Hole 1: $48 \%$; Hole 3: $43 \%$}

This appears to place the rock mass in the category of "fair", borderline to "poor" [10]. On the other hand, the 22-m diameter DIAMOND FORTUNE cavity was stable with no more than bolt/shotcrete reinforcement.

The following paragraph sheds more light of the physical and mechanical properties of this rock mass.

\subsection{BOREHOLE JACK TESTS}

An NX-borehole jack [11, 12], leased from SINCO in Seattle, Washington, was used for a series of tests in hole 3. Eighteen measurements, in alternating horizontal and vertical directions, were performed; the hydraulic line pressure was up to $20.7 \mathrm{MPa}$ ( $3000 \mathrm{psi})$. Of these, eight showed an oversize hole, which in six cases precluded a measurement; and in the remaining two the jack could be extended only up to a line pressure of $6.9 \mathrm{MPa}$ (1000 psi). At each location there was one cycle of loading-unloading. Tangent modulus values were calculated at 1000, 1500 and 2000 psi, on loading; the results are summarized in Table 2-1.

There appears to be a good correlation between the in-situ modulus and the RQD. This is illustrated in Figures 2-6. Where E could not be measured because of hole oversize, its value was assumed to be as low as the nearest low value. The tangent modulus at 1000 psi and the 4"-based RQD reflect the same variation of rock quality along the hole.

\footnotetext{
* The labels used at the time of drilling were LX-1 and LX-3 respectively.
} 


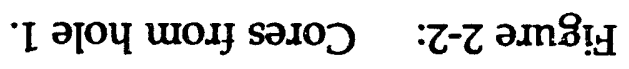

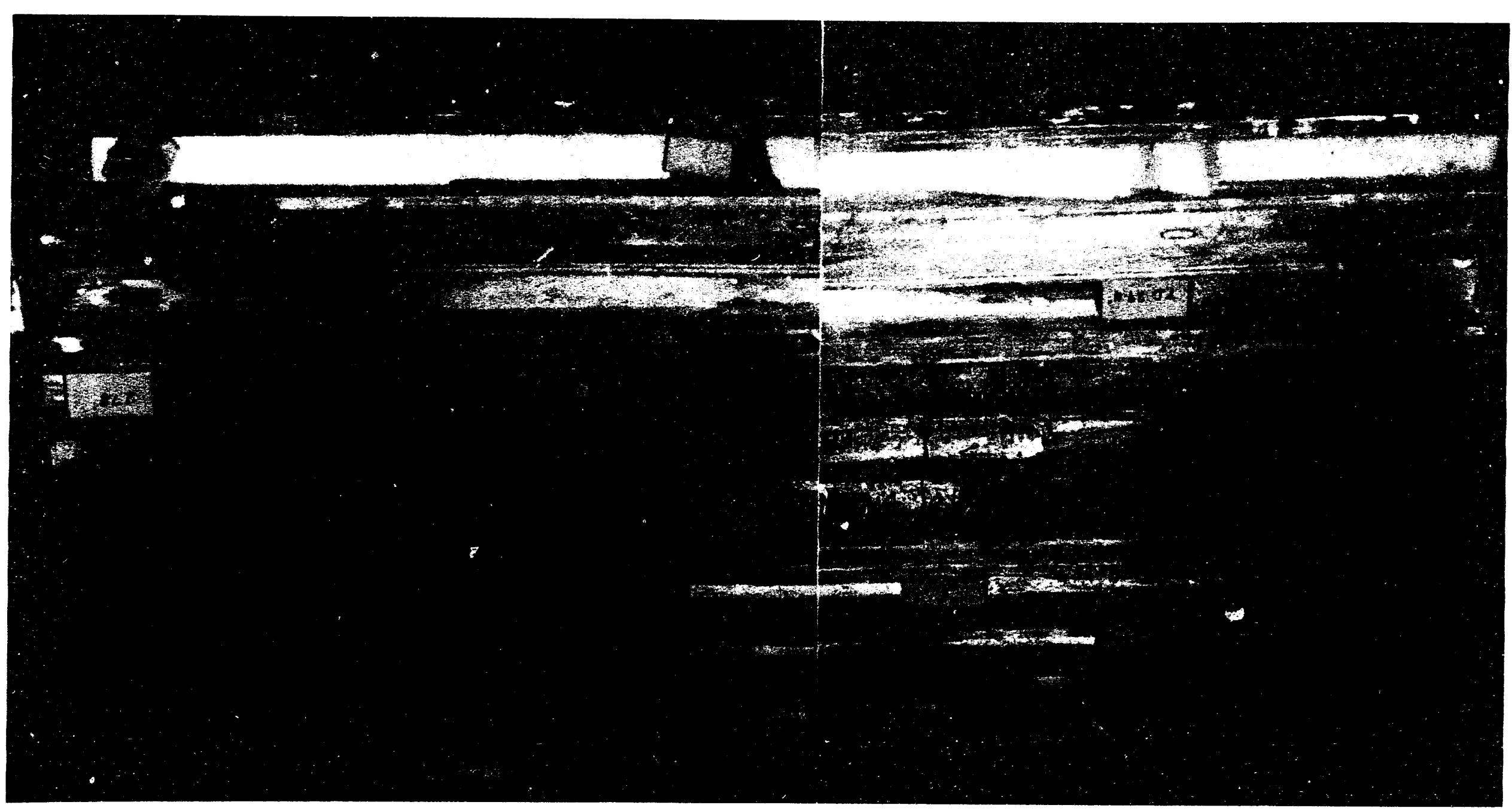




\section{•}

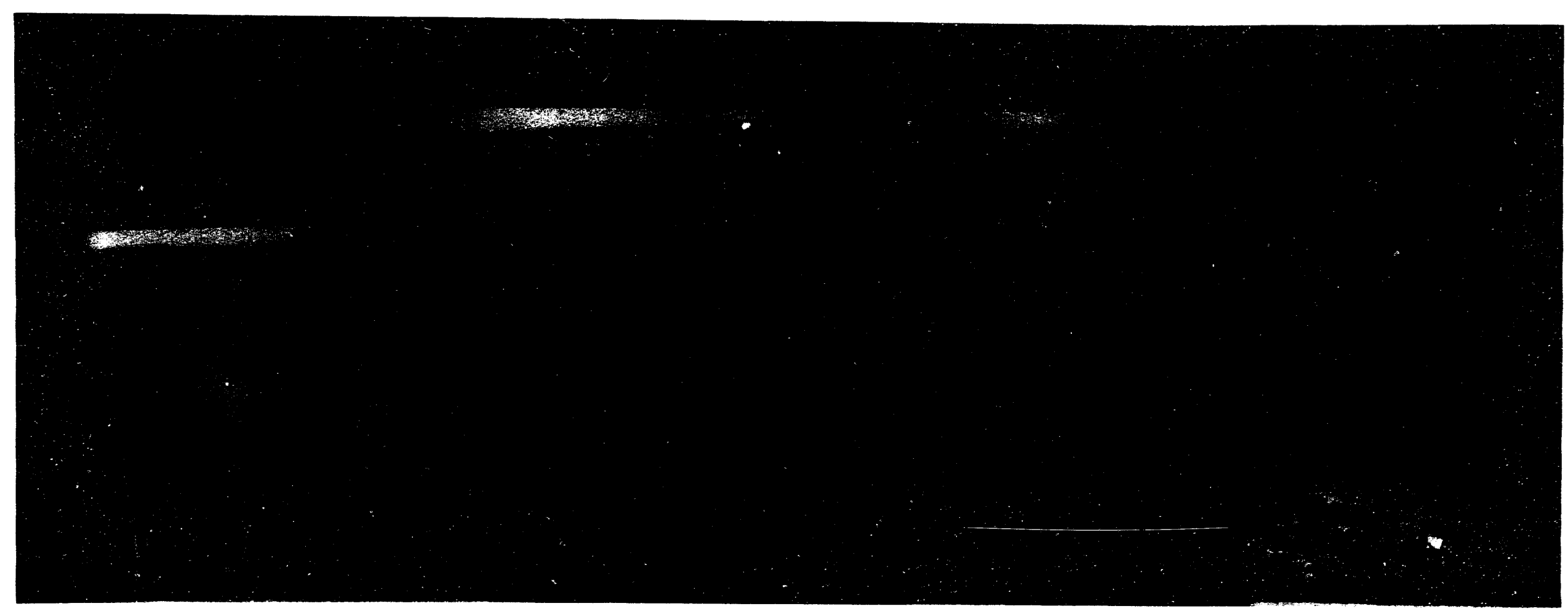




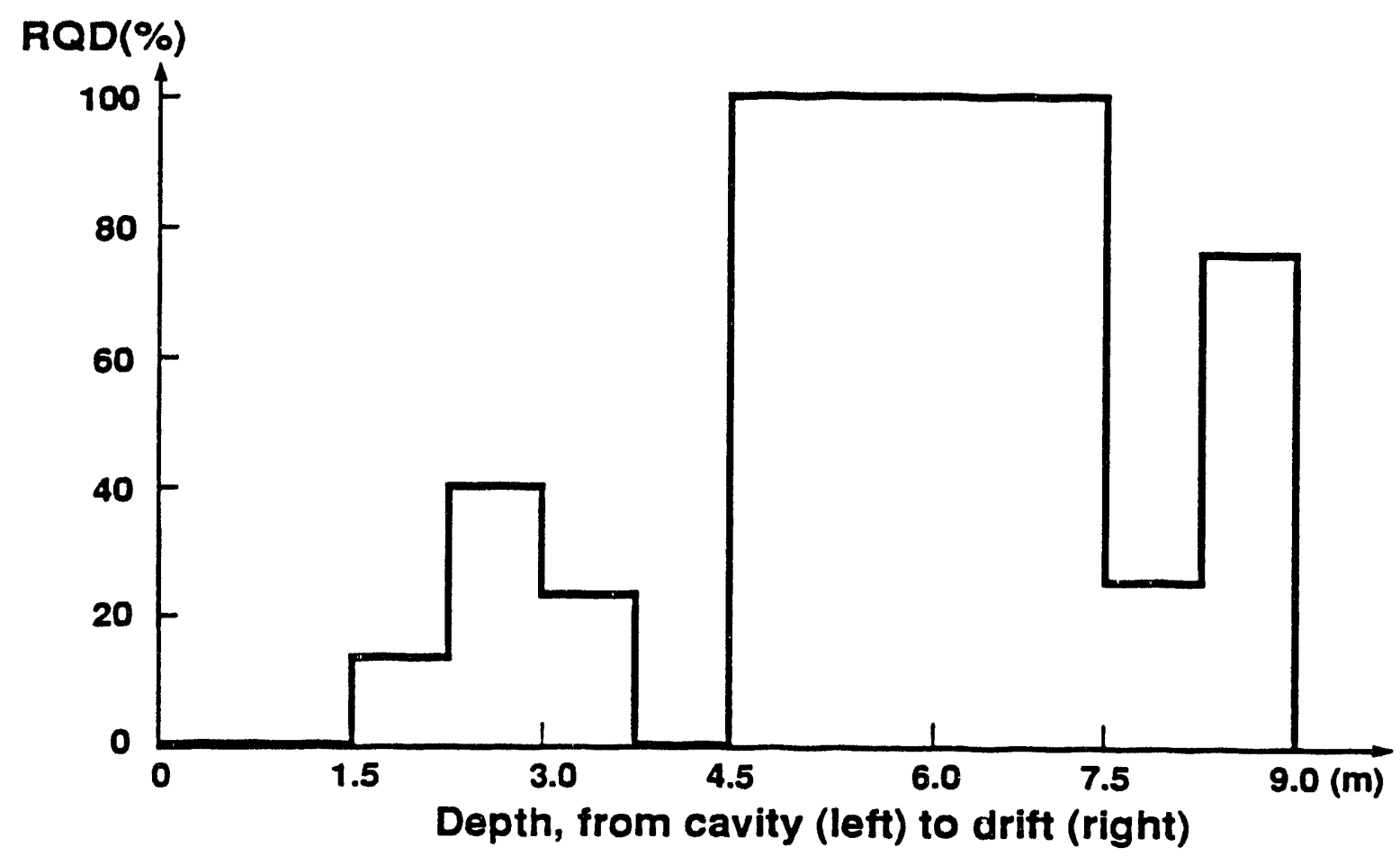

Figure 2-4: $R Q D$, for hole 1.

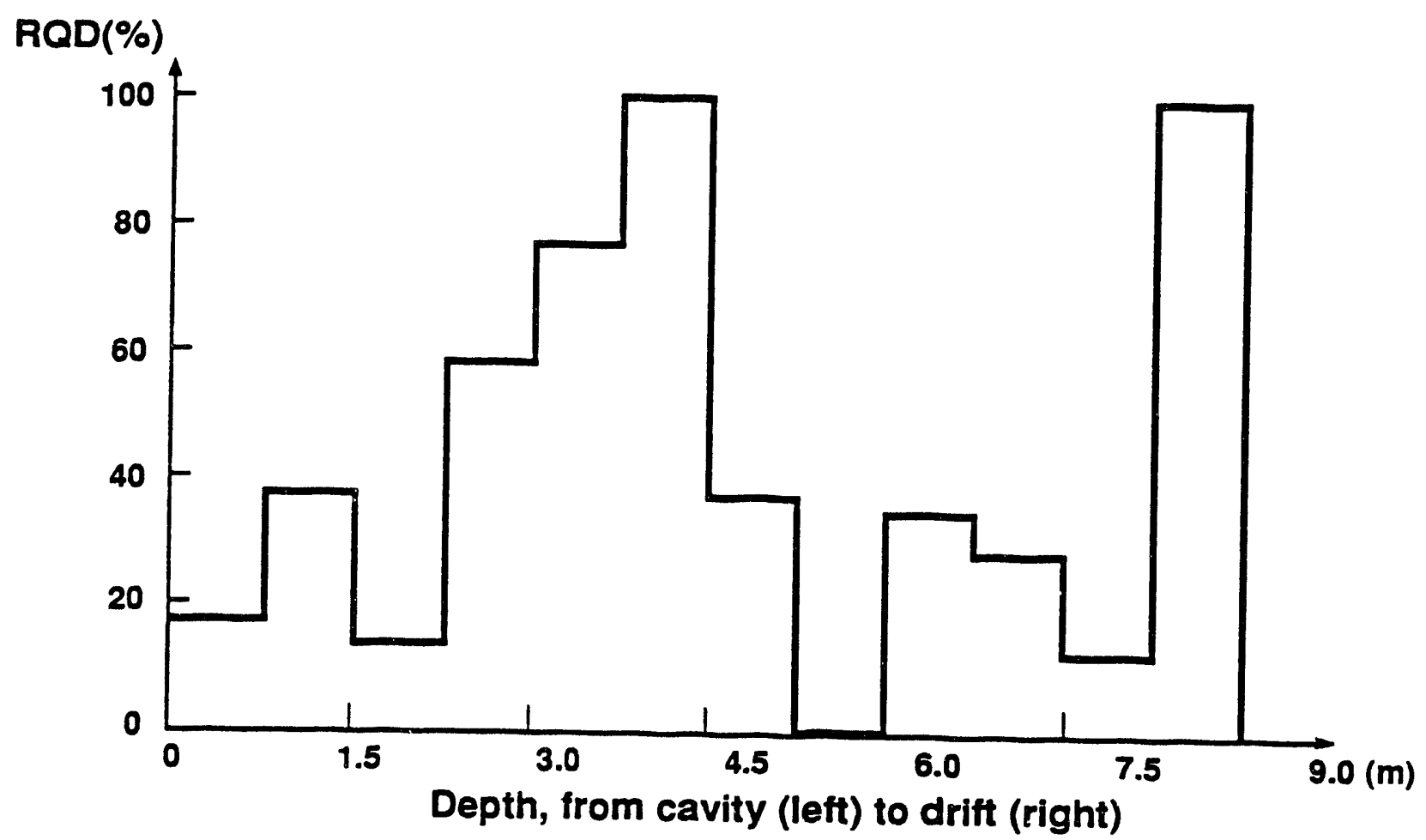

Figure 2-5: RQD, for hole 3. 
Table 2-1 In-situ modulus from NX-jack as a function of line pressure, $Q$.

\begin{tabular}{c|c|c|c|c|c} 
Test & Orient. & $\begin{array}{c}\text { Dept from } \\
\text { cavity (m) }\end{array}$ & $\begin{array}{c}\text { Q=6.9 MPa } \\
(1000 \mathrm{psi})\end{array}$ & $\begin{array}{c}\mathrm{Q}=10.3 \mathrm{MPa} \\
(1500 \mathrm{psi})\end{array}$ & $\begin{array}{c}\mathrm{Q}=13.8 \mathrm{MPa} \\
(2000 \mathrm{psi})\end{array}$ \\
\hline 1 & $\mathrm{H}$ & 0.25 & 1.06 & 1.36 & 1.40 \\
2 & $\mathrm{~V}$ & 0.86 & 1.36 & 1.36 & 1.40 \\
3 & $\mathrm{H}$ & 1.62 & 1.59 & 1.19 & 1.03 \\
4 & $\mathrm{~V}$ & 2.38 & 1.19 & 1.19 & 1.08 \\
5 & $\mathrm{H}$ & 3.15 & 1.36 & 1.36 & 1.59 \\
6 & $\mathrm{~V}$ & 3.91 & 2.38 & 2.38 & 2.16 \\
7 & $\mathrm{H}$ & 4.67 & 2.38 & 2.38 & 2.97 \\
8 & $\mathrm{~V}$ & 5.44 & 1.19 & -- & -- \\
9 & $\mathrm{H}$ & 5.74 & - & - & - \\
10 & $\mathrm{H}$ & 6.05 & 0.86 & 0.79 & 0.72 \\
11 & $\mathrm{~V}$ & 6.81 & - & - & - \\
12 & $\mathrm{H}$ & -6.81 & 0.68 & 0.63 & 0.59 \\
13 & $\mathrm{~V}$ & 7.57 & - & -- & -- \\
14 & $\mathrm{H}$ & 7.57 & - & -- & - \\
15 & $\mathrm{H}$ & 7.87 & - & -- & - \\
16 & $\mathrm{H}$ & 8.17 & - & -- & - \\
17 & $\mathrm{~V}$ & 8.48 & 1.90 & 2.14 & - \\
18 & $\mathrm{H}$ & 8.79 & 1.59 & -- &
\end{tabular}

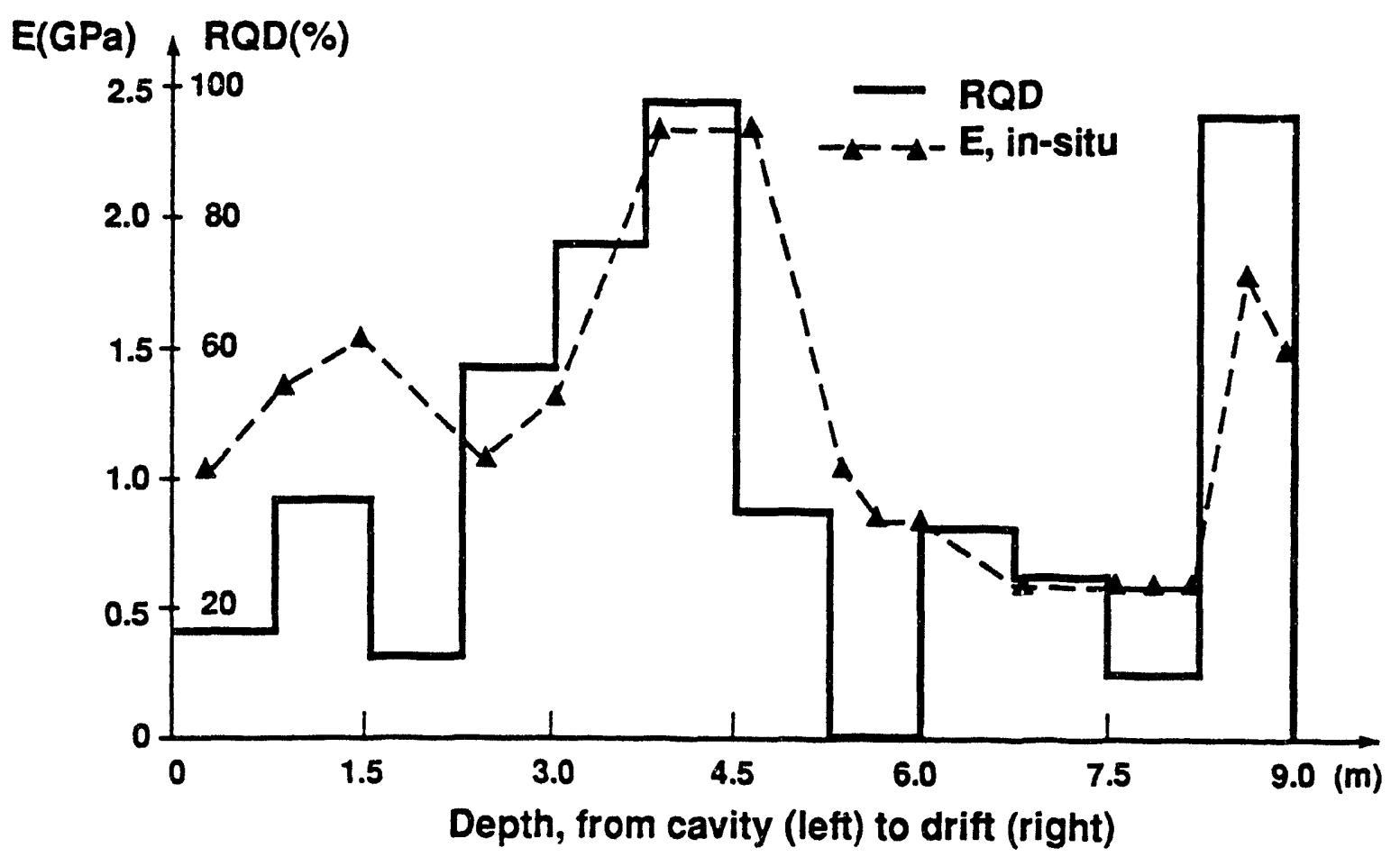

Figure 2-6: In-situ modulus vs RQD in hole 3. 


\subsection{PROPERTIES OF ROCK MATERIALS}

Three core sections from hole 3 were selected for physical and mechanical tests. They are labeled A, B, and C. Each section yielded 2 or more specimens for testing. The locations, away from the cavity were:

section $A: \quad 8.27$ to $8.61 \mathrm{~m}$ deep, gave samples $\mathrm{A}-1, \mathrm{~A}-2$

section B: $\quad 4.27$ to $4.64 \mathrm{~m}$ deep, gave samples B-1, B-2, B-3

section C: 2.61 to $3.06 \mathrm{~m}$ deep, gave samples $\mathrm{C}-1, \mathrm{C}-2, \mathrm{C}-3$

Since these cores were selected for their competence, they slearly are from locations of higher RQD in hole 3.

\subsubsection{Physical Properties}

The samples were received in wax-coated aluminum foil. Test specimens were machined by cutting and grinding. Dry density was determined, after drying in a vacuum chamber at $35^{\circ} \mathrm{c}$. Sample A-1 was unsaturated, to determine porosity. Physical characteristics are shown in Table 2.2.

Table 2.2: Physical characteristics of samples from hole 3.

\begin{tabular}{lllll} 
Sample & $\begin{array}{l}\text { Diam. } \\
(\mathrm{cm})\end{array}$ & $\begin{array}{l}\text { Length } \\
(\mathrm{cm})\end{array}$ & $\begin{array}{l}\text { Porosity } \\
(\%)\end{array}$ & $\begin{array}{l}\text { Dry density } \\
\left(\mathrm{g} / \mathrm{cm}^{3}\right)\end{array}$ \\
\hline A-1 & 3.813 & 7.633 & 32.1 & 1.597 \\
A-2 & 3.823 & 7.617 & - & 1.612 \\
B-1 & 3.823 & 7.617 & - & 1.649 \\
B-2 & 3.823 & 7.623 & - & 1.649 \\
B-3 & 3.823 & 7.617 & 32.3 & 1.569 \\
C-1 & 3.823 & 7.623 & - & 1.395 \\
C-2 & 3.823 & 7.620 & - & 1.391 \\
C-3 & 3.823 & 7.620 & 41.8 & 1.399
\end{tabular}




\subsubsection{Sonic Velocities}

Sample A-1, B-1, and C-1 were used for P-and S-wave velocity tests, $V_{p}$ was obtained on all three and $V_{S}$ obtained on $B-1$ and $C-1$. The velocities were measured at several confining hydrostatic (all around) pressures, from zero to $5.52 \mathrm{MPa}(800 \mathrm{psi})$. The results are shown in Table 2-3.

Table 2-3: Sonic velocities, as a function of confining pressure, for cores from hole 3.

\begin{tabular}{lllll} 
Sample & $\begin{array}{c}\text { Confining } \\
(\mathrm{MPa})\end{array}$ & $\begin{array}{l}\text { Pressure } \\
(\mathrm{psi})\end{array}$ & $\begin{array}{l}\mathrm{V}_{\mathrm{p}} \\
(\mathrm{km} / \mathrm{s})\end{array}$ & $\begin{array}{l}\mathrm{V}_{\mathrm{s}} \\
(\mathrm{km} / \mathrm{s})\end{array}$ \\
\hline A-1 & 0. & 0 & 2.10 & - \\
& 2.76 & 400 & 2.80 & - \\
B-1 & 5.52 & 800 & 3.23 & - \\
& 0 & 0 & 3.12 & 1.88 \\
& 2.76 & 400 & 3.29 & 2.33 \\
C-1 & 5.52 & 800 & 3.33 & 2.81 \\
& 0 & 0 & 2.19 & 1.44 \\
& 2.76 & 400 & 2.46 & 1.78 \\
& 5.52 & 800 & 2.67 & 2.00
\end{tabular}

There is a marked increase in velocities with confinements in all but the $V_{p}$ for sample B-1, which, as shown next, was the most competent of all specimens. The next paragraph also shows that the range of 0 to $5 \mathrm{MPa}$ compressive stress is one of highly non-linear behavior for those materials. Thus, it would not be meaningful to calculate Poisson's ratio values from the above $V_{p}$ and $V_{s}$, in such a stress range.

\subsubsection{Triaxial Compressive Tests}

Triaxial compression tests were performed on 5 cores from sections A, B, C. The axial stress vs axial strain records are shown in Figure 2-7. The peak axial stress $\left(\sigma_{1} \mathrm{max}\right)$, the axial strain at failure $\left(\varepsilon_{1 \mathrm{f}}\right)$, and the tangent modulus at $50 \%$ of peak stress $\left(E_{l a b}\right)$ are summarized in Table 2-4. The table also indicates the ratio of field to laboratory moduius, $E_{f} / E_{l a b}$, for these locations in hole 3 . The modulus reduction from lab to field is consistent with previous experience in a large number of rocks [13]. 


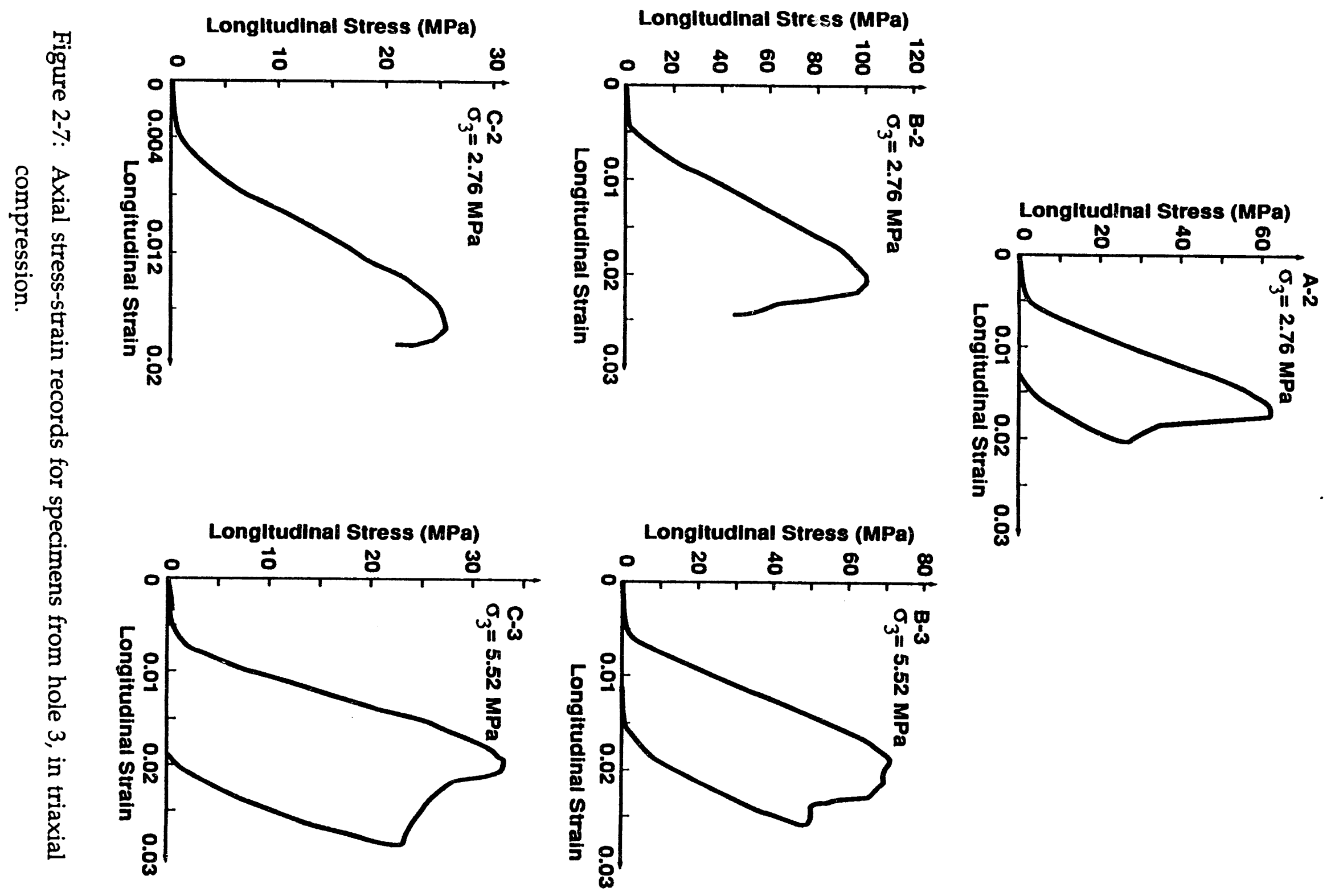


Table 2-4: $\quad$ Mechanical properties of samples from hole 3.

\begin{tabular}{|c|c|c|c|c|c|}
\hline Sample & $\begin{array}{l}\sigma_{3} \\
(\mathrm{MPa})\end{array}$ & $\begin{array}{l}\sigma_{1 \max } \\
(\mathrm{MPa})\end{array}$ & $\begin{array}{l}\varepsilon_{1 \mathrm{f}} \\
\left(10^{-2}\right)\end{array}$ & $\begin{array}{l}\mathrm{E}_{\mathrm{lab}} \\
(\mathrm{GPa})\end{array}$ & Ejack/Elab \\
\hline A-2 & 2.76 & 62.5 & 1.68 & 6.23 & 0.22 \\
\hline $\begin{array}{l}\text { B-2 } \\
\text { B-3 }\end{array}$ & $\begin{array}{l}2.76 \\
5.52\end{array}$ & $\begin{array}{l}101 .- \\
71.5\end{array}$ & $\begin{array}{l}2.06 \\
1.87\end{array}$ & $\begin{array}{l}7.52 \\
6.19\end{array}$ & $\begin{array}{l}0.32 \\
0.38\end{array}$ \\
\hline $\begin{array}{l}\mathrm{C}-2 \\
\mathrm{C}-3\end{array}$ & $\begin{array}{l}2.76 \\
5.52\end{array}$ & $\begin{array}{l}26 .- \\
33.3\end{array}$ & $\begin{array}{l}1.72 \\
1.95\end{array}$ & $\begin{array}{l}2.67 \\
2.95\end{array}$ & $\begin{array}{l}0.32 \\
0.29\end{array}$ \\
\hline
\end{tabular}

\subsubsection{Summary}

The data from tables 2-1 through 2-4 consistently show a lack of homogeneity in physical and mechanical properties through the pillar of tuff between the cavity and the run-around drift. They also show that the samples at mid-pillar (core section B) are denser, stiffer, and stronger than the other cores. This is consistent with the field modulus being the highest of hole 3 at the location of core section B.

\subsection{PROPERTIES OF THE GROUT}

Six grout castings were received from the batch used to grout the space between the CONVEX steel plate and the rock, and test samples were prepared from these. A suite of physical, wave, and compression tests was performed on these samples in a fashion similar to that for rock materials. By the time of testing, the grout was well beyond 30 days of curing. The sonic velocities were measured at atmospheric pressure, and the Poisson's ratio calculated as:

$$
v=\left(V_{p}^{2}-2 V_{s}^{2}\right) / 2\left(V_{p}^{2}-V_{s}^{2}\right)
$$

The results are summarized in Table 2-5. They show that this grout is very similar to the Section $C$ cores in density, wave speed, stiffness, and strength. 
Table 2-5: Summary of properties measured for the HLNCC grout used behind the CONVEX plate.

\begin{tabular}{|c|c|c|c|c|c|c|c|c|c|}
\hline $\begin{array}{l}\text { Sample } \\
\text { Identifi- } \\
\text { cation: } \\
\text { HLNCC- }\end{array}$ & $\begin{array}{l}\text { Diam. } \\
(\mathrm{cm})\end{array}$ & $\begin{array}{l}\text { Length } \\
(\mathrm{cm})\end{array}$ & $\begin{array}{l}\text { Dry } \\
\text { Density } \\
\left(\mathrm{g} / \mathrm{cm}^{3}\right)\end{array}$ & $\begin{array}{l}\mathrm{V}_{\mathrm{p}} \\
(\mathrm{km} / \mathrm{s})\end{array}$ & $\begin{array}{l}V_{s} \\
(\mathrm{~km} / \mathrm{s})\end{array}$ & $v$ & $\begin{array}{l}\sigma_{3} \\
(\mathrm{MPa})\end{array}$ & $\begin{array}{l}\sigma_{1 \max } \\
(\mathrm{MPa})\end{array}$ & $\begin{array}{l}\mathrm{E} \\
(\mathrm{GPa})\end{array}$ \\
\hline $14.8-1$ & 3.80 & 7.58 & 1.292 & -- & - & - & 2.76 & 26.-- & 2.83 \\
\hline $14.8-2$ & 3.80 & 7.58 & 1.306 & -- & -- & - & 0 & 19.3 & 3.13 \\
\hline $14.8-3$ & 3.80 & 7.58 & 1.334 & 2.50 & 1.51 & 0.213 & -- & - & -- \\
\hline $14.9-1$ & 3.80 & 7.58 & 1.346 & -- & -- & - & 0 & 21.1 & 3.76 \\
\hline $14.9-2$ & 3.80 & 3.78 & 1.330 & -- & -- & - & 0 & 24.1 & 3.56 \\
\hline $14.9-3$ & 3.80 & 3.89 & 1.366 & 2.61 & 1.56 & 0.222 & - & - & - \\
\hline
\end{tabular}




\section{SECTION 3}

\section{LINER SYSTEM INSTALLATION}

\subsection{HARDWARE}

\subsubsection{Liner Components}

The design of the liner system is shown in vertical cross section in Figure 3-1. Its main components are:

- the $1.4 \mathrm{~m} \times 1.4 \mathrm{~m}$ steel plate, made of A.36 steel, 2.54-cm thick [15]

- the four corner bolts: two 4.7-m long sections joined by a coupling; the bars are 2.54- $\mathrm{cm}$ in diameter and made of cold drawn 1045 steel [16]. The bars were purchased from Nucor Cold Finish, Brigham City, UT.

- the center bolt: two $4.7-\mathrm{m}$ long sections, joined by a coupling; the bars are $5.08-\mathrm{cm}$ in diameter and also made of cold drawn 1045 steel.

- a $11.43-\mathrm{cm}$ O.D., Sch 40 , steel pipe with a wall thickness of $6.02 \mathrm{~mm}$. This casing is grouted in the center hole (figure 2-1). It houses the center bolt. The annulus between the casing and the center bolt is filled with Vistanex.

- on the cavity ("front") side: A36 steel bearing plates between the bolt nuts and the main liner plates. These bearing plates were welded around their edges to the liner plate, to render the system more monolithic. For that same purpose, nuts also were placed on the bolts behind the liner plate, and tightened.

- on the run-around ("back") side: A36 steel bearing plates resting on Sulfaset pads built on the rock surface (Sulfaset is a sulfur-cement mixture, made by Randustrial Corporation, Cleveland, $\mathrm{OH}$ ). As illustrated in Figure 3-1, these plates are heavier than those on the front side, particularly the plate for the center bolt as it was to sustain and distribute on the rock the large reaction force from the center bolt tension.

- the drift side also had a rather elaborate closure device that enabled the various strain-gage cables coming out of the center bolt to exit behind the bearing plate. 


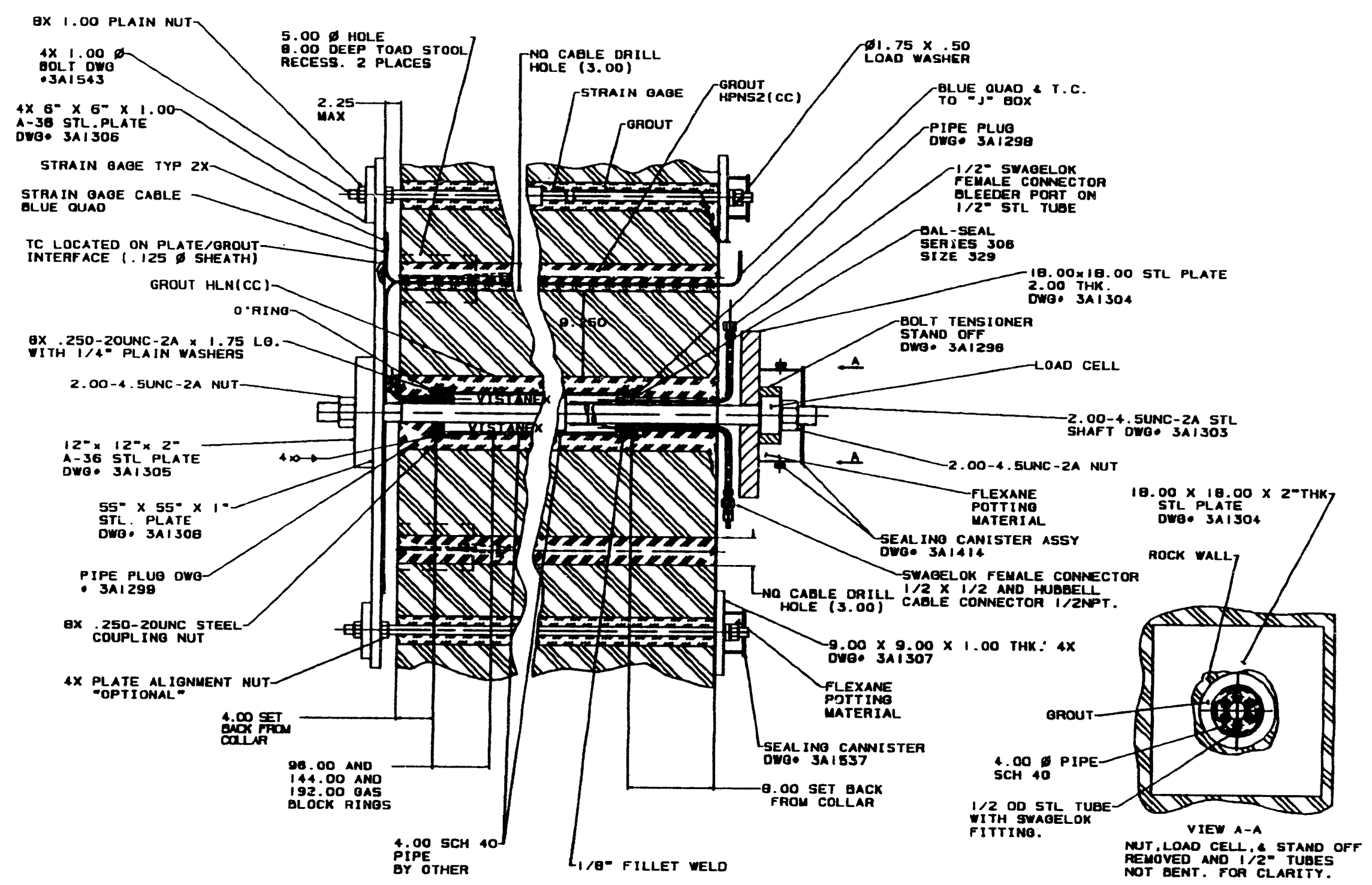

Figure 3-1: Vertical cross-section of the liner-bolt system. 


\subsubsection{Steel Properties}

The mechanical properties of the A36 and 1045 steels relevant to the CONVEX test are summarized in Table 3-1. Note that the strength values shown are static; these values are likely to be higher under dynamic loading. The thermal properties are discussed in chapter 5.

Table 3-1: Mechanical properties of CONVEX liner steels, after [15, 16].

\begin{tabular}{|c|c|c|c|c|c|c|c|c|}
\hline & \multirow{2}{*}{$\begin{array}{l}\text { Density } \\
\mathrm{g} / \mathrm{cm}^{3}\end{array}$} & \multirow{2}{*}{\multicolumn{2}{|c|}{$\begin{array}{l}\text { Young's } \\
\text { Modulus }\end{array}$}} & \multicolumn{2}{|c|}{ Yield Stress } & & \multirow{2}{*}{$\begin{array}{l}\text { Linear } \\
\text { Expansion } \\
/{ }^{\circ} \mathrm{C}\end{array}$} \\
\hline & & & $\begin{array}{l}\text { ulus } \\
10^{6} \mathrm{psi}\end{array}$ & $\mathrm{MPa}$ & ksi & $\begin{array}{l}\text { Tens } \\
\text { MPa }\end{array}$ & $\begin{array}{r}\text { tress } \\
\text { ksi }\end{array}$ & \\
\hline A36 & 7.8 & 200 & 29 & 248 & 36 & 428 & 62 & $6.3 \times 10^{-6}$ \\
\hline 1045 & 7.85 & 193 & 28 & 759 & 110 & 862 & 125 & $11.2 \times 10^{-6}$ \\
\hline
\end{tabular}

\subsection{INSTALLATION PROCEDURE}

This paragraph contains a summary of the installation, and a sequential photographic record of the progress of construction (Figures 3-2 to 3-15).

The sequence of liner system installation was as follows:

- drill all the holes (Figures 2-1 and 2-2)

- case the center bolt hole, and grout the casing

- smooth out the rock surface on the cavity side, to provide for a planar area behind the plate

- install the two toadstool stress gages on the cavity side; they were set to protrude about $2.5 \mathrm{~cm}$ from the rock, so as to be in the middle of the $5-\mathrm{cm}$ layer of grout to be pumped behind the liner plate

- build the Sulfaset bearing pads on the drift side

- set the 5 bolts in their holes, with centering fixtures. The corner bolt in hole 6 and the center bolts were equipped with strain gages, and the cables exited through the drift side

Note: throughout this report, the "left" or "right" side location of corner bolts will be defined as viewed from the cavity side and facing the liner plate. 
- set the bearing steel plates in the drift, and the nuts on the back side of the bolts. The nuts are finger-tip tight

- install the center bolt casing caps, front and back, and thread the strain-gage cables through the back assembly

- mount the liner plate to the wall, threading all the instrumentation cables through holes 1 and 3. This was done on February 19, 1992

- grout the $5-\mathrm{cm}$ space between the liner plate and the cavity wall. Let the grout cure for five days

- tension all 5 bolts from the run-around drift. A SOP (Standard Operating Procedure) was written up for this test, and the tensioning started on February 27. Initially, one of the corner bolts was about 10 percent high. Adjustments were made in the next few days and the steady tensions achieved were $3.62 \pm$ $0.05 \mathrm{MN}(35,500 \pm 500 \mathrm{lbs})$ on the corner bolts and $15.05 \mathrm{MN}(147,600 \mathrm{lbs})$ on the center bolt, for a tensile stress of 312 to $324 \mathrm{MPa}(45.2$ to $47.0 \mathrm{ksi})$ in the bars.

- grout the four corner bolts

- install the 3 FCP's on the cavity side and thread cables to the drift

- install the rock pillar accelerometer in hole 1

- grout the FCP and accelerometer holes

- fill the center hole annulus, between the bolt and casing, with Vistanex

- connect the instrument cables to the junction box ("J Box").

Figures 3-2 to 3-15 illustrate the construction process. After the center bolt hole was cased, the installation of the entire system was completed over a period of about 7 weeks (mid-February to early April 1992).

The run-around drift was pumped full of grout starting on April 14. 


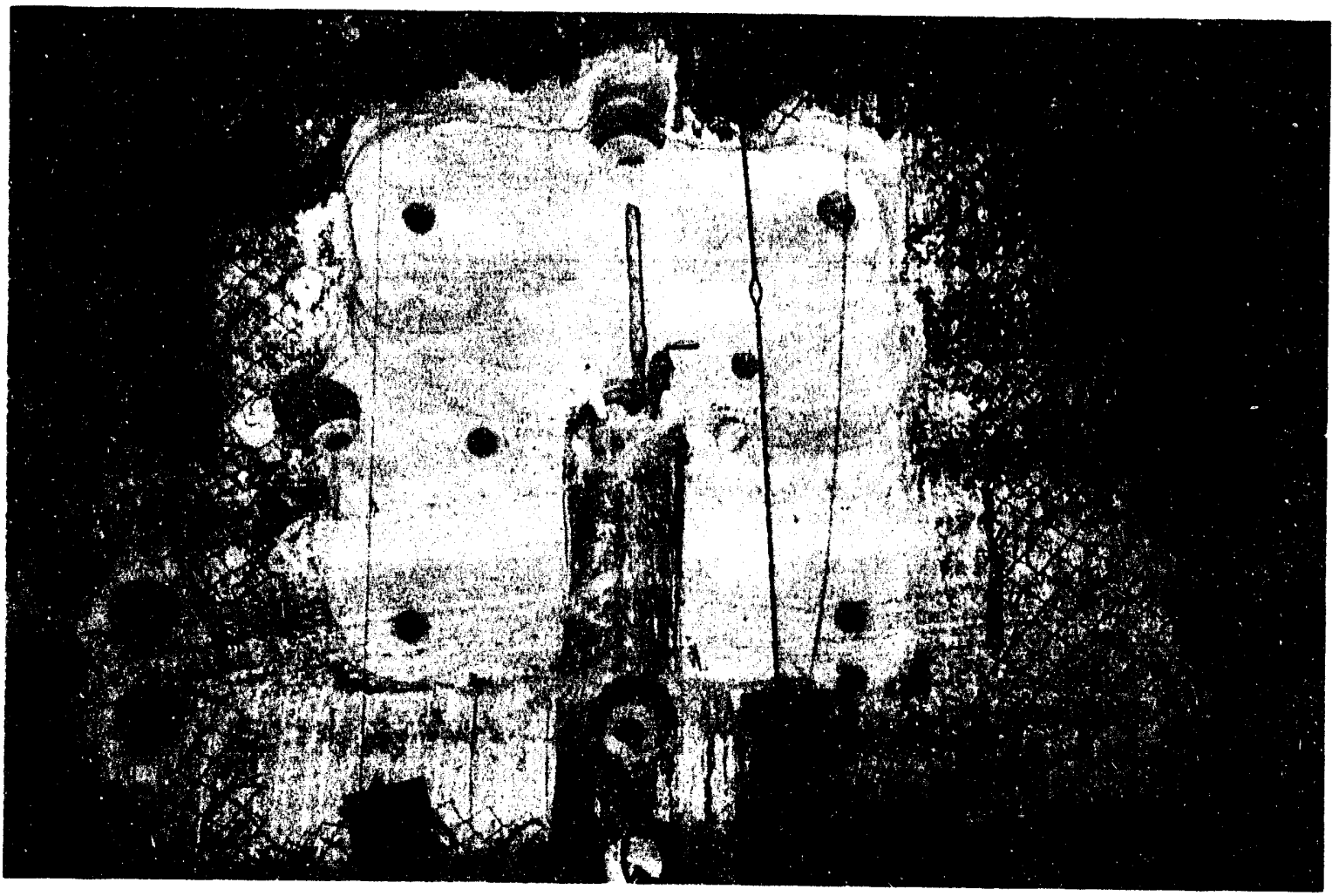

Figure 3-2: Liner plate area smoothed out, and drill holes.

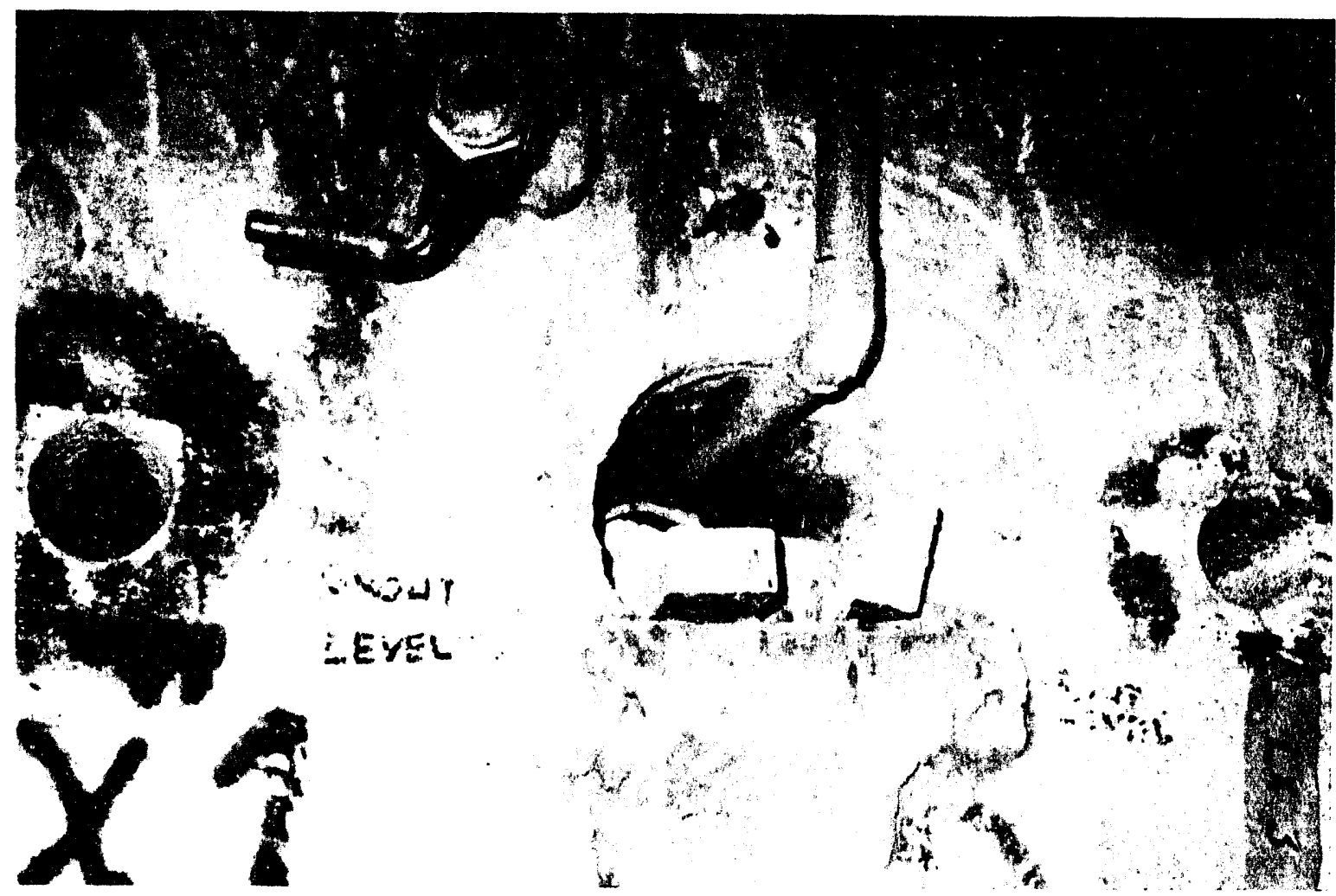

Figure 3-3: Drift side; casing grouted in center hole. 

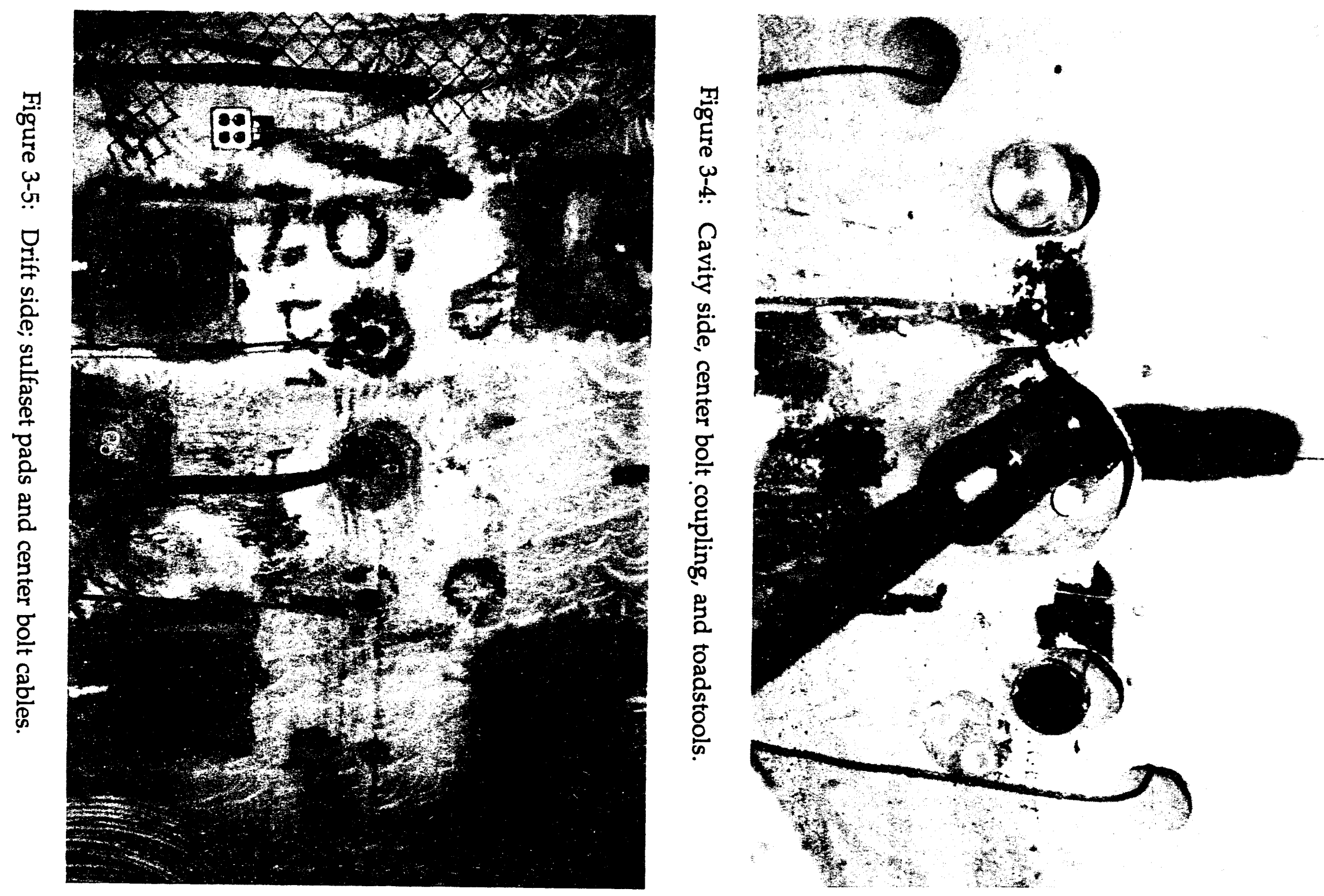

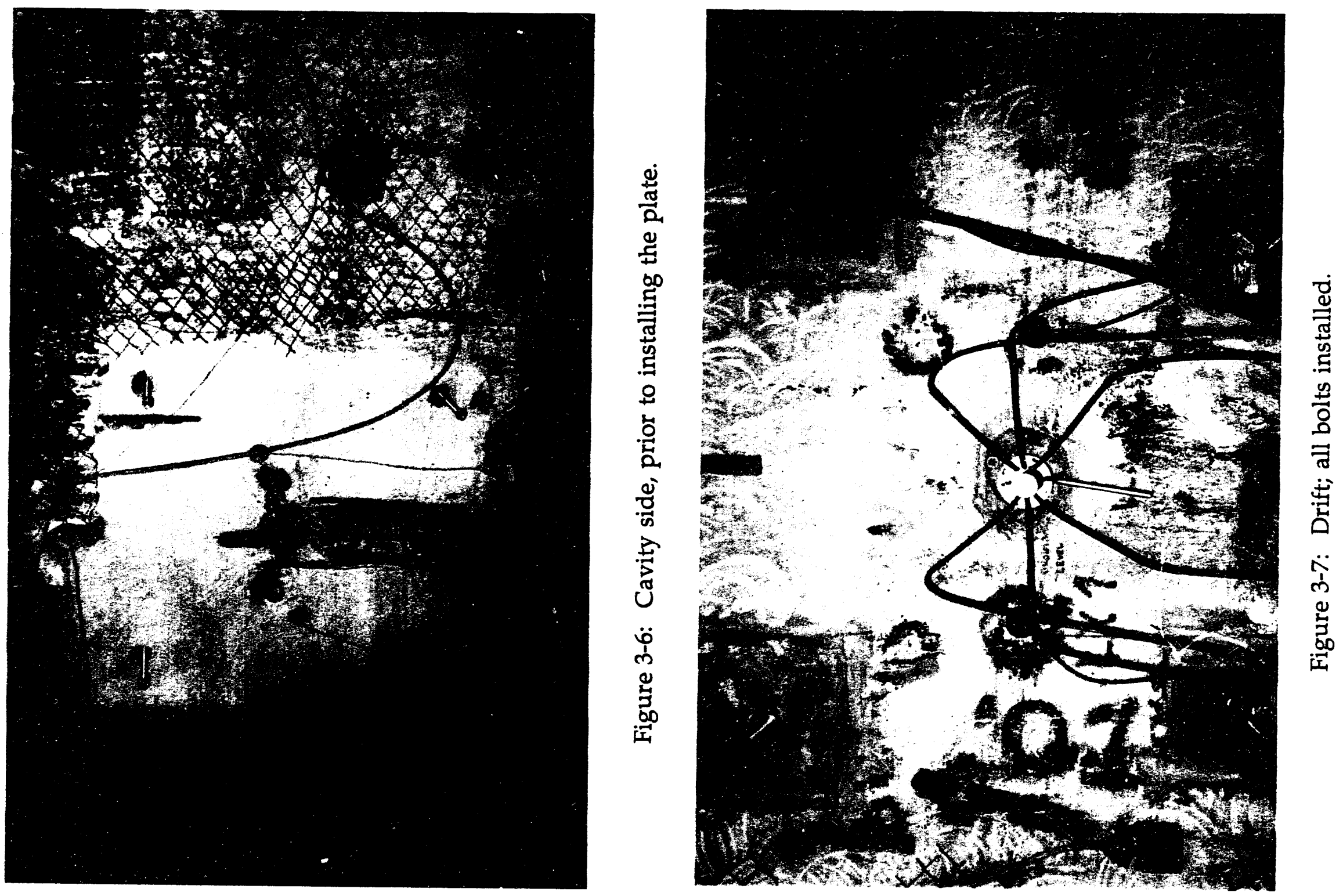
Figure 3-8:

Instrumented

liner plate.

独 


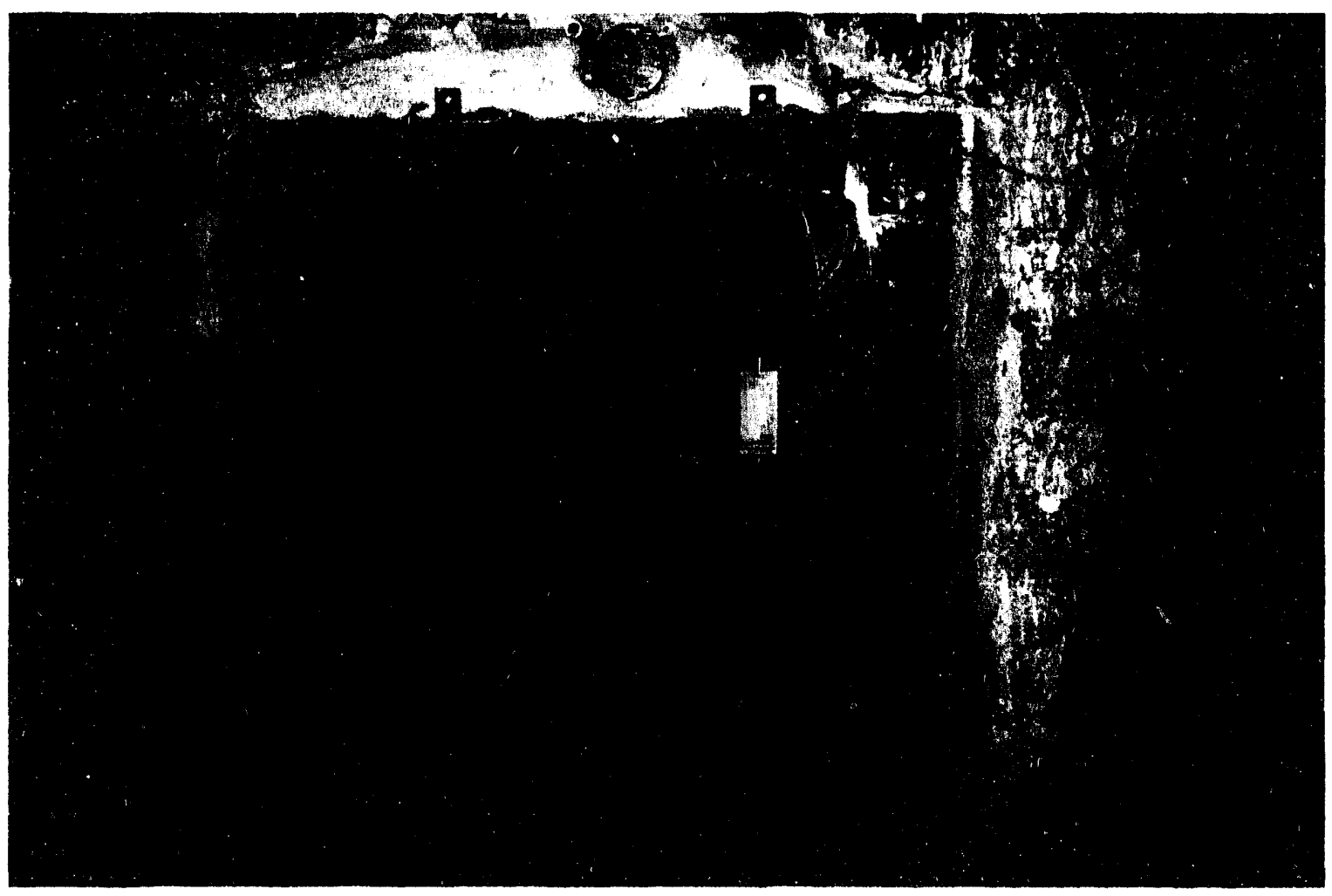

Figure 3-10: Microseismic monitoring during bolt tensioning.

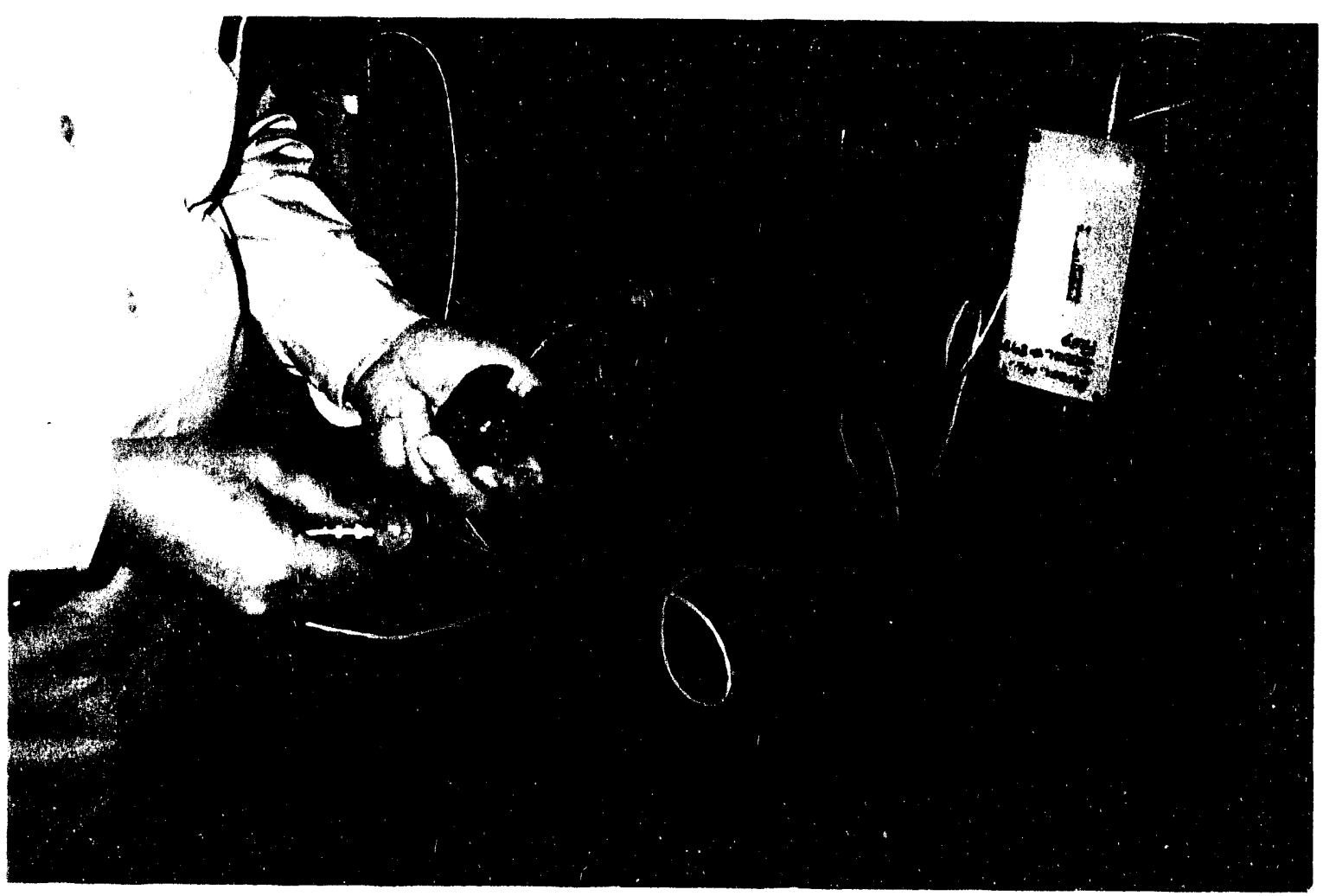

Figure 3-11: Tranducers, holders, and signal conditioners. 


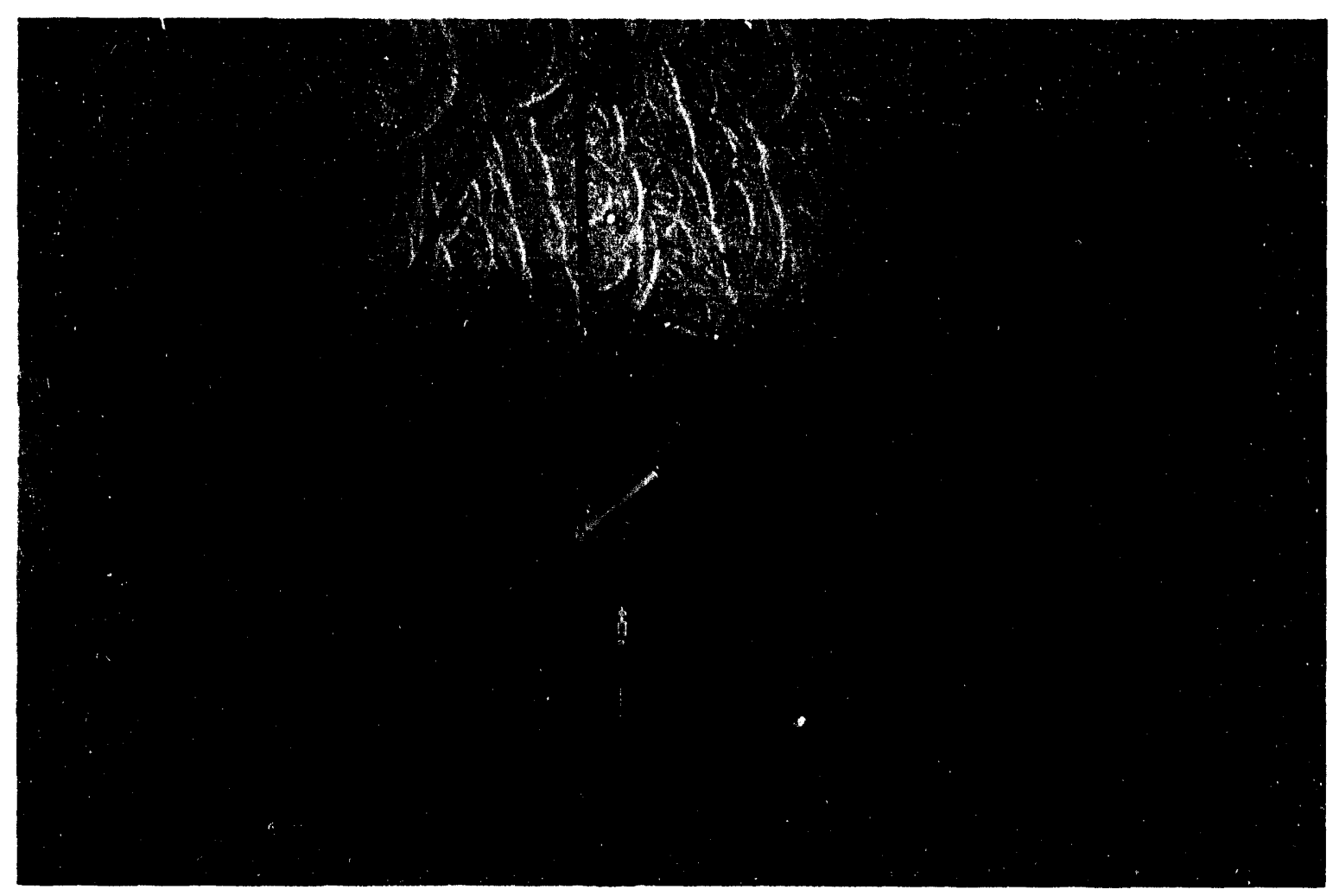

Figure 3-12: Drift; bolt pattern and cables

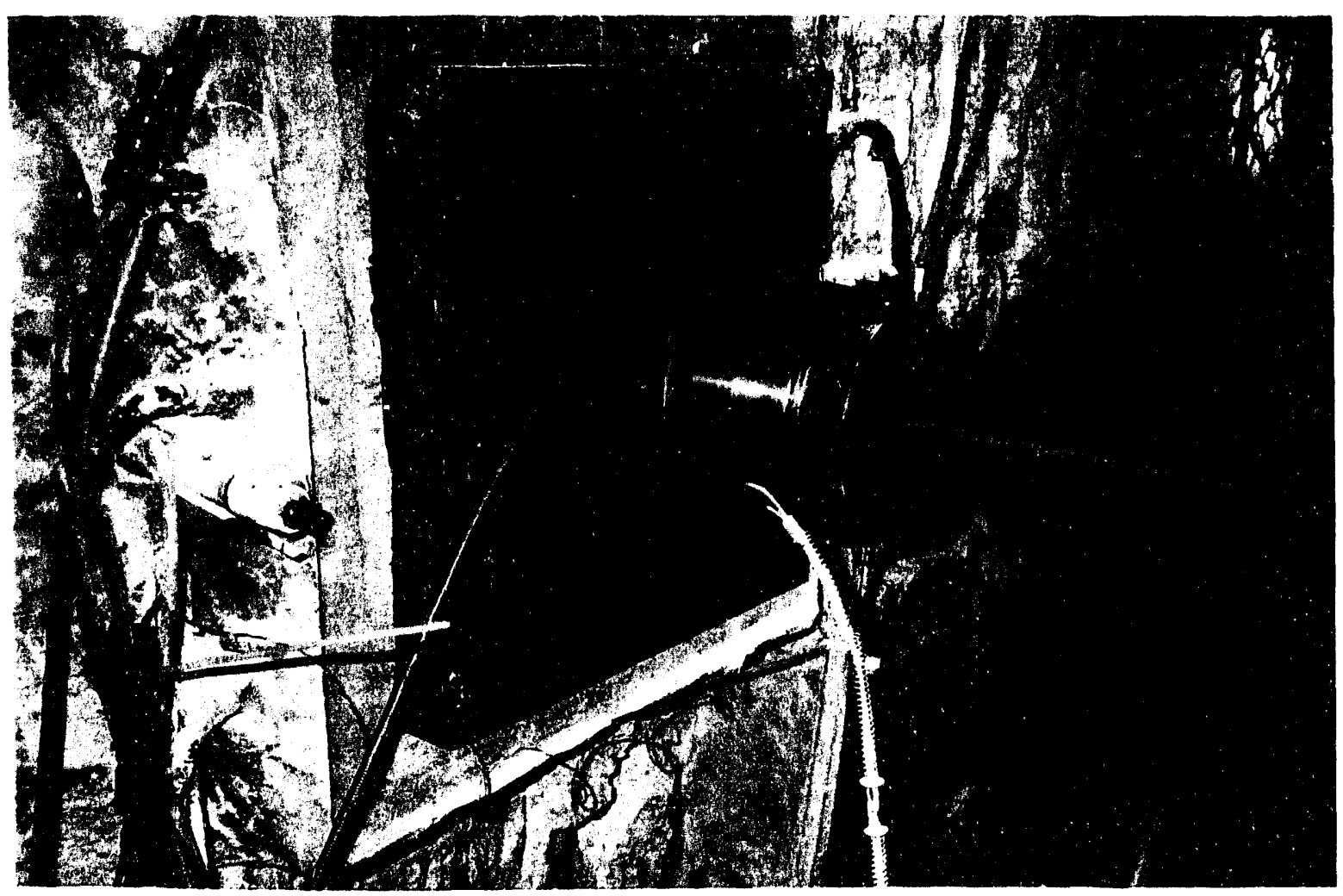

Figure 3-13: Drift; jack and load cell for center bolt tensioning. 


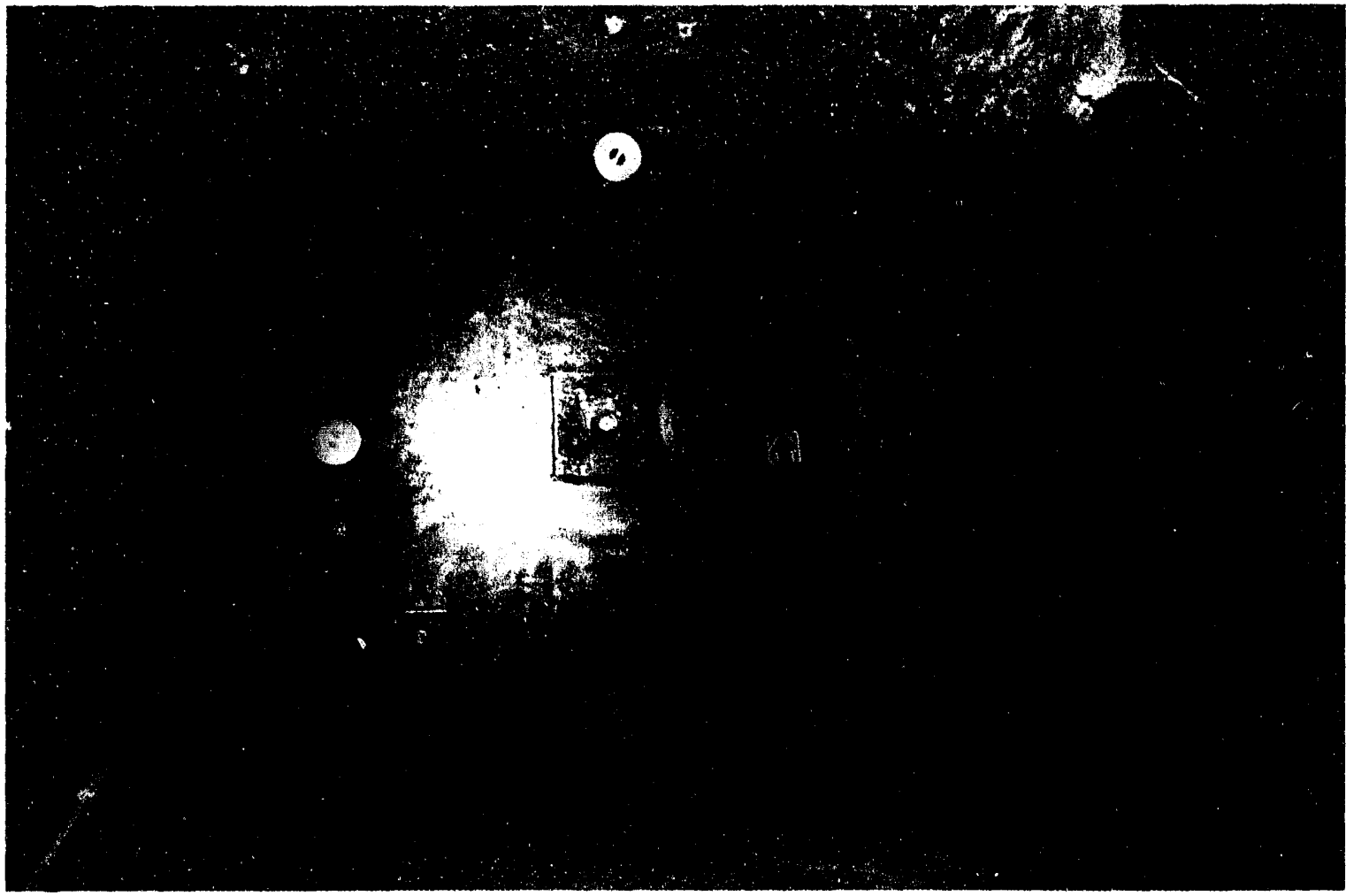

Figure 3-14: Cavity; CONVEX liner ready for testing.

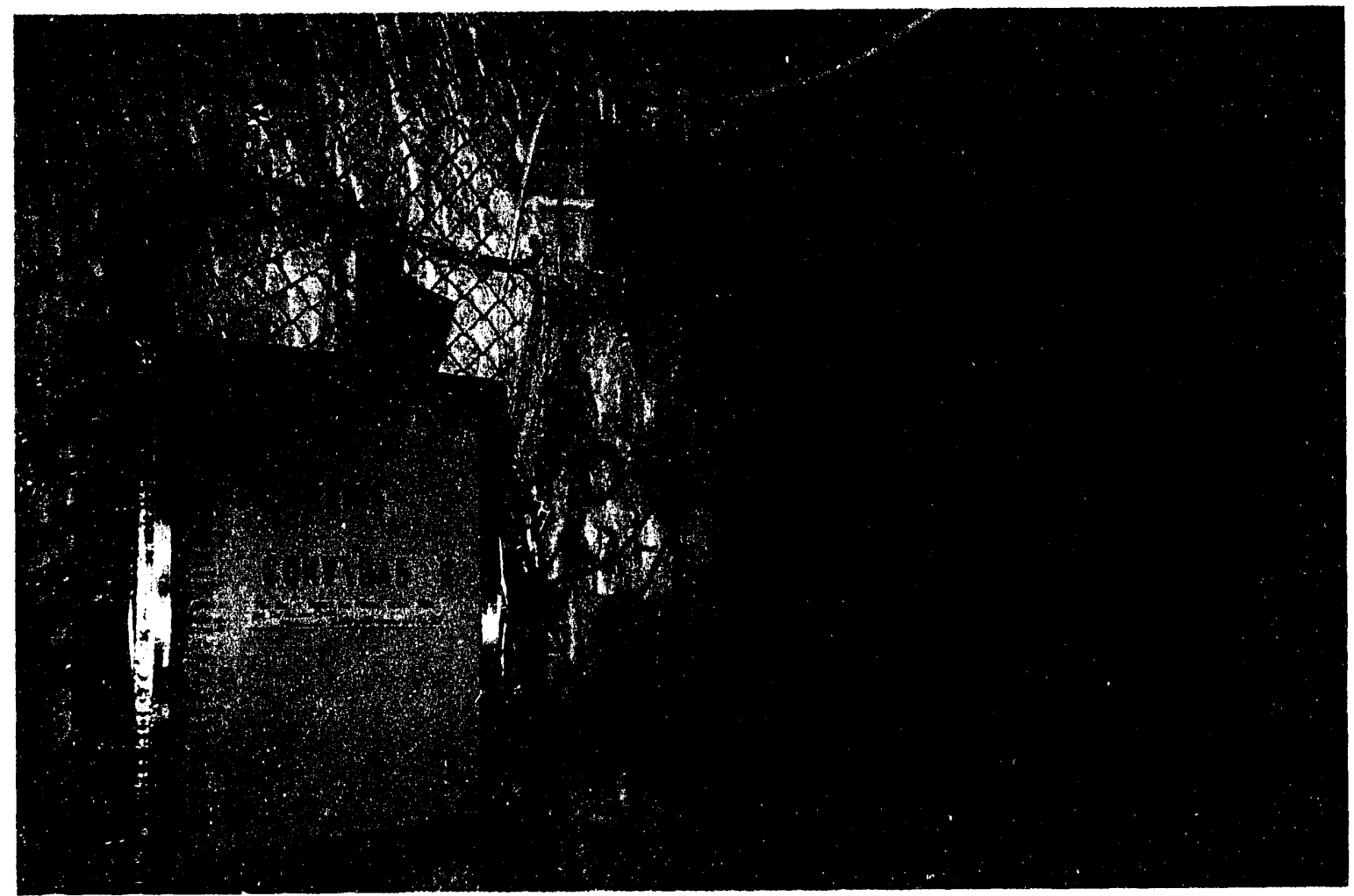

Figure 3-15: Drift; system ready prior to grouting of drift. 


\section{SECTION 4}

\section{INSTRUMENTATION AND DATA ACQUISITION}

\subsection{GAGE DESCRIPTION}

Detailed specifications for the gages outlined in Table 1-1 are given in Table 4-1. They include make, model, lot number, mechanical range and thermal range.

\subsection{GAGE INSTALLATION}

\subsubsection{Plate Gages}

Two $90^{\circ}$ strain gage rosettes were installed on the rear surface of the plate on the horizontal centerline, midway between the vertical centerline and each outside edge. The gages were aligned to coincide with the vertical and horizontal axes of the plate to measure the vertical and horizontal strains at symmetrical locations. Gages 7100 and 7110 were vertical; gages 7105 and 7115 were horizontal. Back-up gages had been planned and installed on the plate. This turned out to be a good idea: due to a failure of the primary gages on the right-hand side of the plate (facing the plate), the back up gages were used. This means that the right-hand gages were $0.102 \mathrm{~m}$ further from the vertical centerline of the plate $(0.457 \mathrm{~m})$ than were the left-hand gages $(0.357 \mathrm{~m})$. Figures $4-1$ and 4-2 show the design of gage mounting, top and side views. Figures 4-3 and 4-4 show the implementation on the CONVEX liner plate. The plate thrormocouple and accelerometer were placed as close to the left strain gage location as their respective protective enclosures would allow. The thermocouple was embedded half-sheath thickness into the plate.

\subsubsection{Bolt Gages}

Two locations on the center bolt, 5.016 and $5.321 \mathrm{~m}$ from its working point end, each were instrumented with two strain gages oriented longitudinally along the length of the bolt, $180^{\circ}$ apart. The first set (7210 and 7215) was just behind the coupling in the center of the bolt, and the second set (7250 and 7255) was put 30.1 $\mathrm{cm}$ further away from the WP. Figure 4-5 shows the design of gage mounting on the center bolt. Figure 4-6 shows gage station 7215, and Figure 4-7 shows the entire instrumented center bolt. The center bolt load cell was shown on Figure 3-13. 
Table 4-1: Detailed Information on the CONVEX Liner Add-On Gages

\begin{tabular}{|c|c|c|c|c|}
\hline \multirow[t]{2}{*}{ Gage Type } & \multirow[t]{2}{*}{ Gage Model } & \multirow{2}{*}{$\begin{array}{l}\text { Gage Serial } \\
\text { No. }\end{array}$} & \multicolumn{2}{|c|}{ Operational Ranges* } \\
\hline & & & Loads & Temp. $\left({ }^{\circ} \mathrm{F}\right)$ \\
\hline $\begin{array}{l}\text { Loading on rock } \\
\text { accelerometer in } \\
\text { rock pillar }\end{array}$ & Endevco $7270 \mathrm{~A}-60$ & $\mathrm{CN} 32 \mathrm{~F}$ & $60,000 \mathrm{~g}$ & $150^{\circ} \mathrm{F}$ \\
\hline $\begin{array}{l}\text { fluid coupled plates } \\
\text { (FCPs) }\end{array}$ & 2" Kulite HKS-375 & $\begin{array}{l}497-5-15 \\
497-5-7 \\
497-5-10\end{array}$ & $30,000 \mathrm{psi}$ & $300^{\circ} \mathrm{F}$ \\
\hline $\begin{array}{l}\text { Loading on plate } \\
\text { accelerometer }\end{array}$ & Endevco $7270 \mathrm{~A}-200$ & $\mathrm{~A} 90 \mathrm{CF}$ & $200,000 \mathrm{~g}$ & $150^{\circ} \mathrm{F}$ \\
\hline thermocouple & $\begin{array}{l}\text { Gordon Type K } \\
\text { chromel alumel }\end{array}$ & & $\pm 2 \%$ & $2500^{\circ} \mathrm{F}$ \\
\hline strain gages & $\begin{array}{l}\text { Micro- } \\
\text { Measurements } \\
\text { weldable T-rosettes } \\
\text { Model CEA-06- } \\
\text { W250C-120 }\end{array}$ & $\begin{array}{l}\text { Lot no. } \\
\text { R-A38AD685 }\end{array}$ & $\pm 0.5 \%$ & $200^{\circ} \mathrm{F}$ \\
\hline $\begin{array}{l}\text { Plate/Rock interactions } \\
\text { toadstools }\end{array}$ & 2" Kulite HKS-375 & $\begin{array}{l}497-6-20 \\
497-6-22\end{array}$ & $30,000 \mathrm{psi}$ & $300^{\circ} \mathrm{F}$ \\
\hline $\begin{array}{l}\text { Center bolt } \\
\text { load cell }\end{array}$ & $\begin{array}{l}\text { Eaton Lebow } \\
\text { Model 3632-100 }\end{array}$ & 1050 & $150,000 \mathrm{lbs}$ & $200^{\circ} \mathrm{F}$ \\
\hline strain gages & $\begin{array}{l}\text { Micro- } \\
\text { Measurements } \\
\text { weldable } \\
\text { model CEA-06- } \\
\text { W250A-120 }\end{array}$ & $\begin{array}{l}\text { Lot No. } \\
\text { R-A56AD14 }\end{array}$ & $\pm 0.5 \%$ & $200^{\circ} \mathrm{F}$ \\
\hline $\begin{array}{l}\text { Corner bolts } \\
\text { load washer }\end{array}$ & $\begin{array}{l}\text { Eaton Lebow } \\
\text { model } 3632-50\end{array}$ & 7053 & $50,000 \mathrm{lbs}$ & $200^{\circ} \mathrm{F}$ \\
\hline strain gages & $\begin{array}{l}\text { Micro- } \\
\text { Measurements } \\
\text { weldable } \\
\text { model CEA-06- } \\
\text { W250A120 }\end{array}$ & $\begin{array}{l}\text { Lot no. } \\
\text { R-A56AD14 }\end{array}$ & $\pm 0.5 \%$ & $200^{\circ} \mathrm{F}$ \\
\hline
\end{tabular}




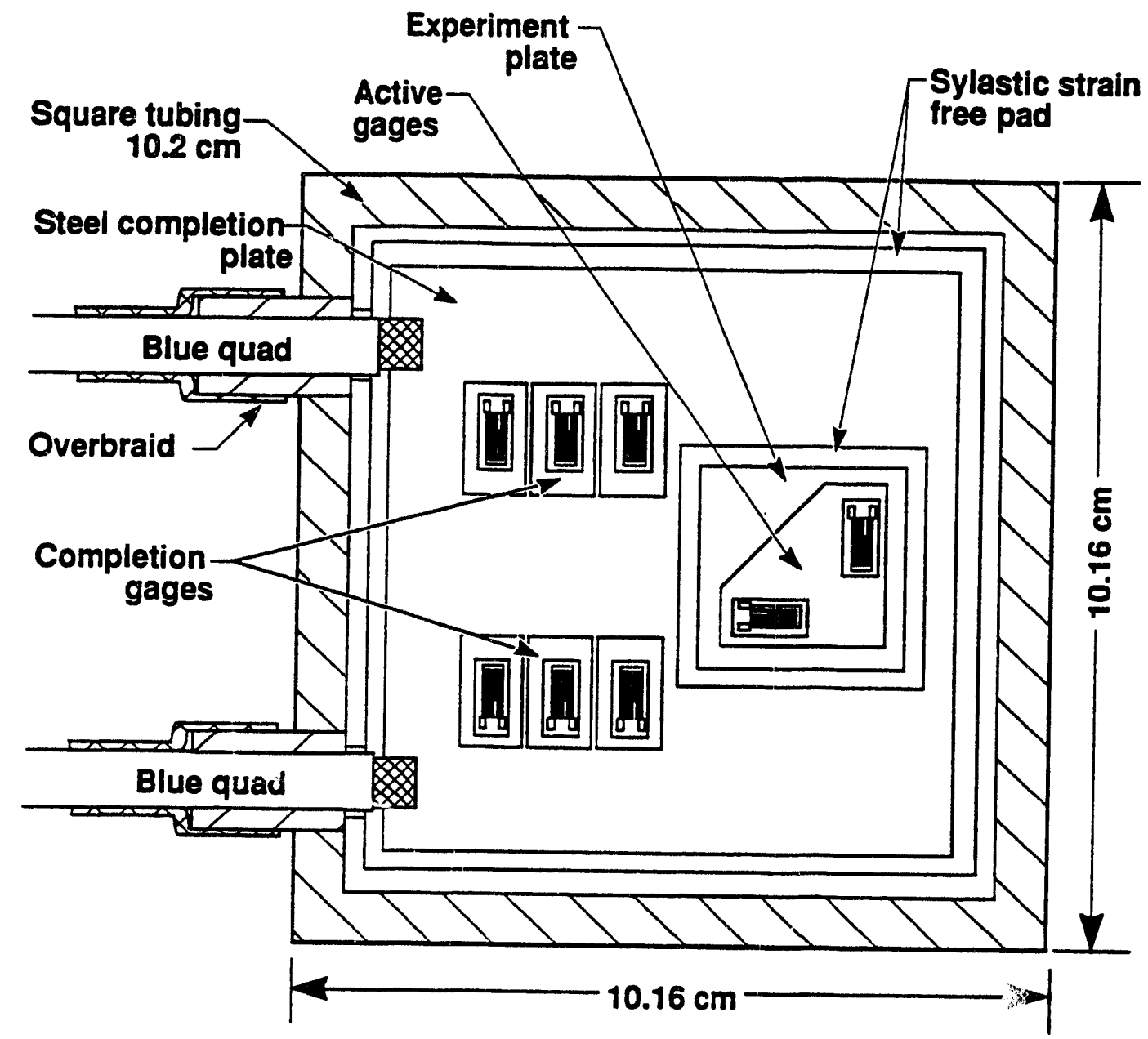

Figure 4-1: Design of plate strain enclosures, top view.

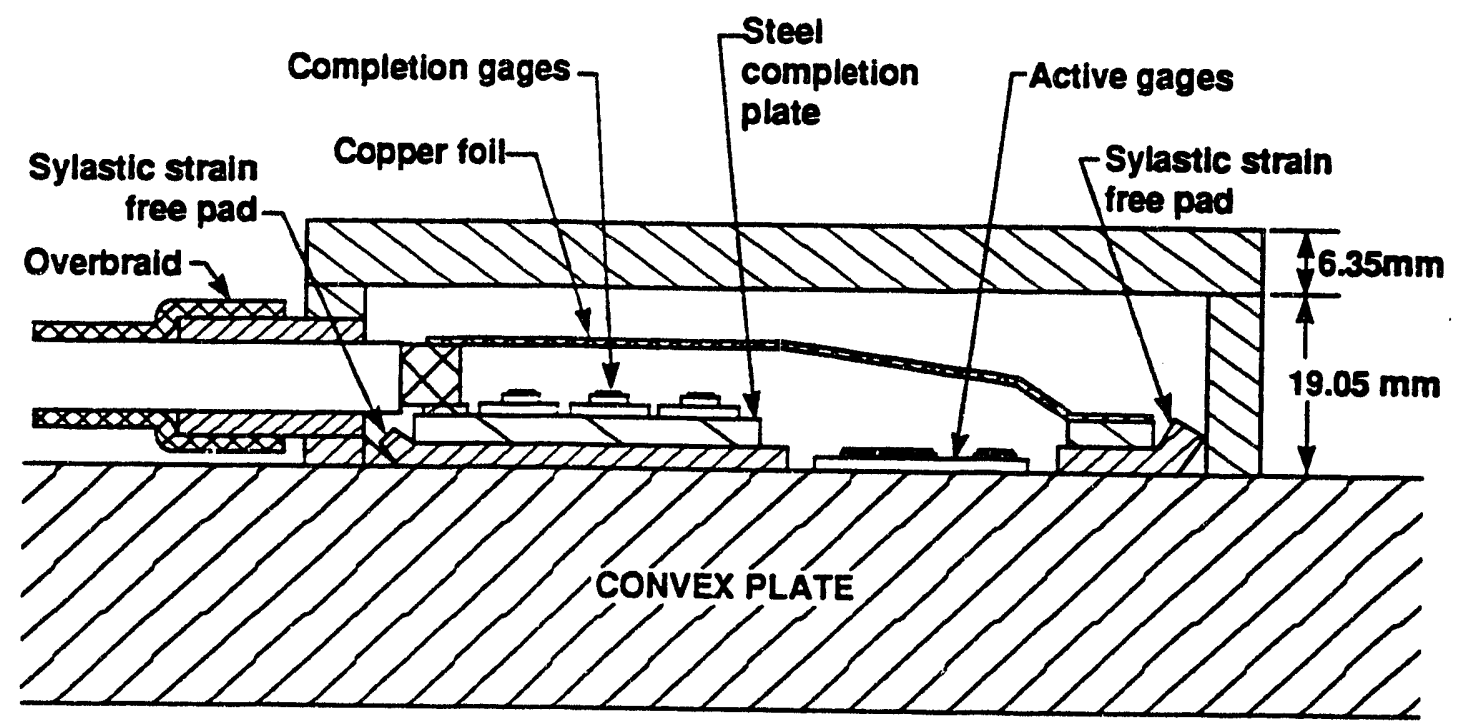

Figure 4-2: Design of plate strain enclosures, side view. 


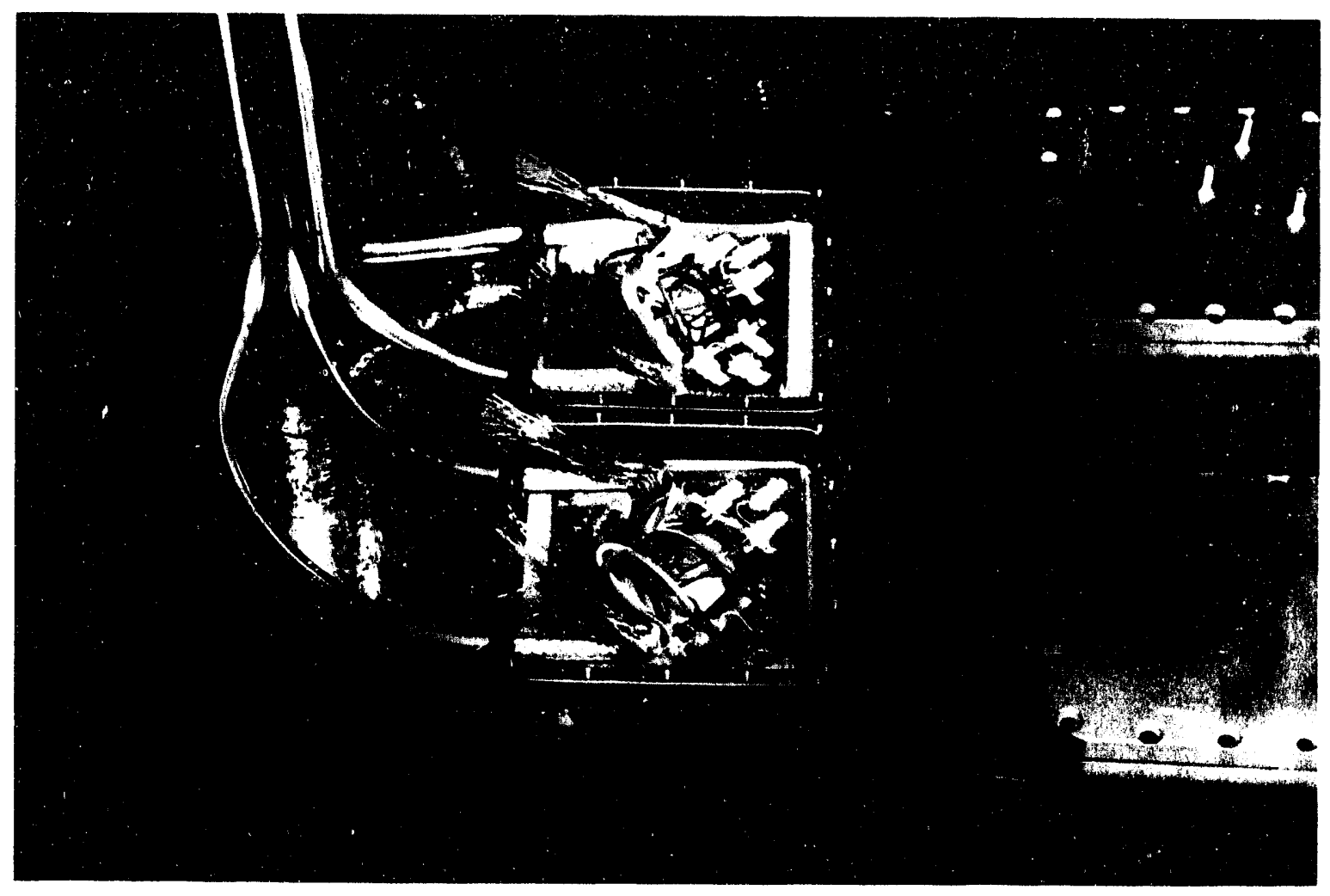

Figure 4-3: Close-up of strain gage stations on plate.

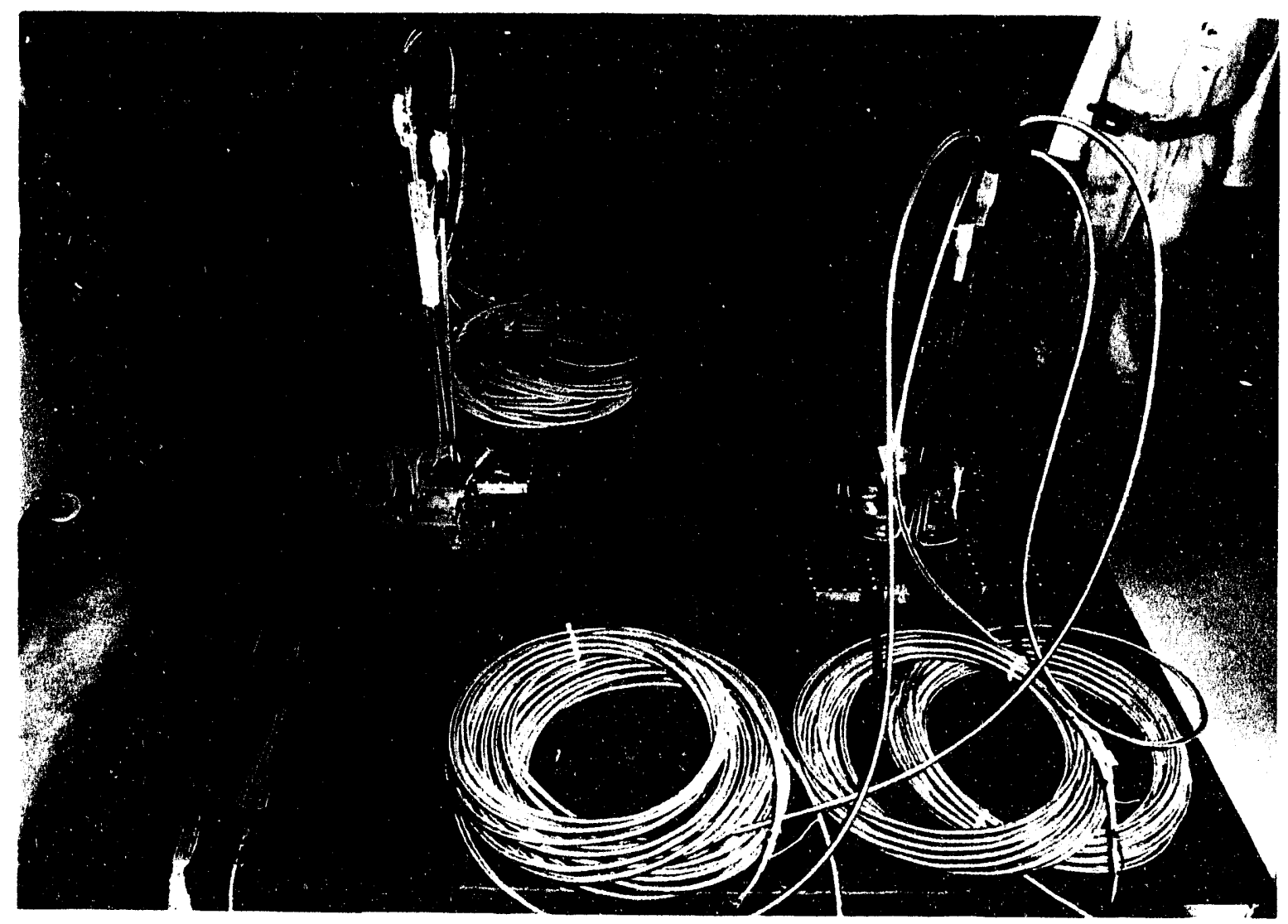

Figure 4-4: Back of instrumented CONVEX liner plate. 


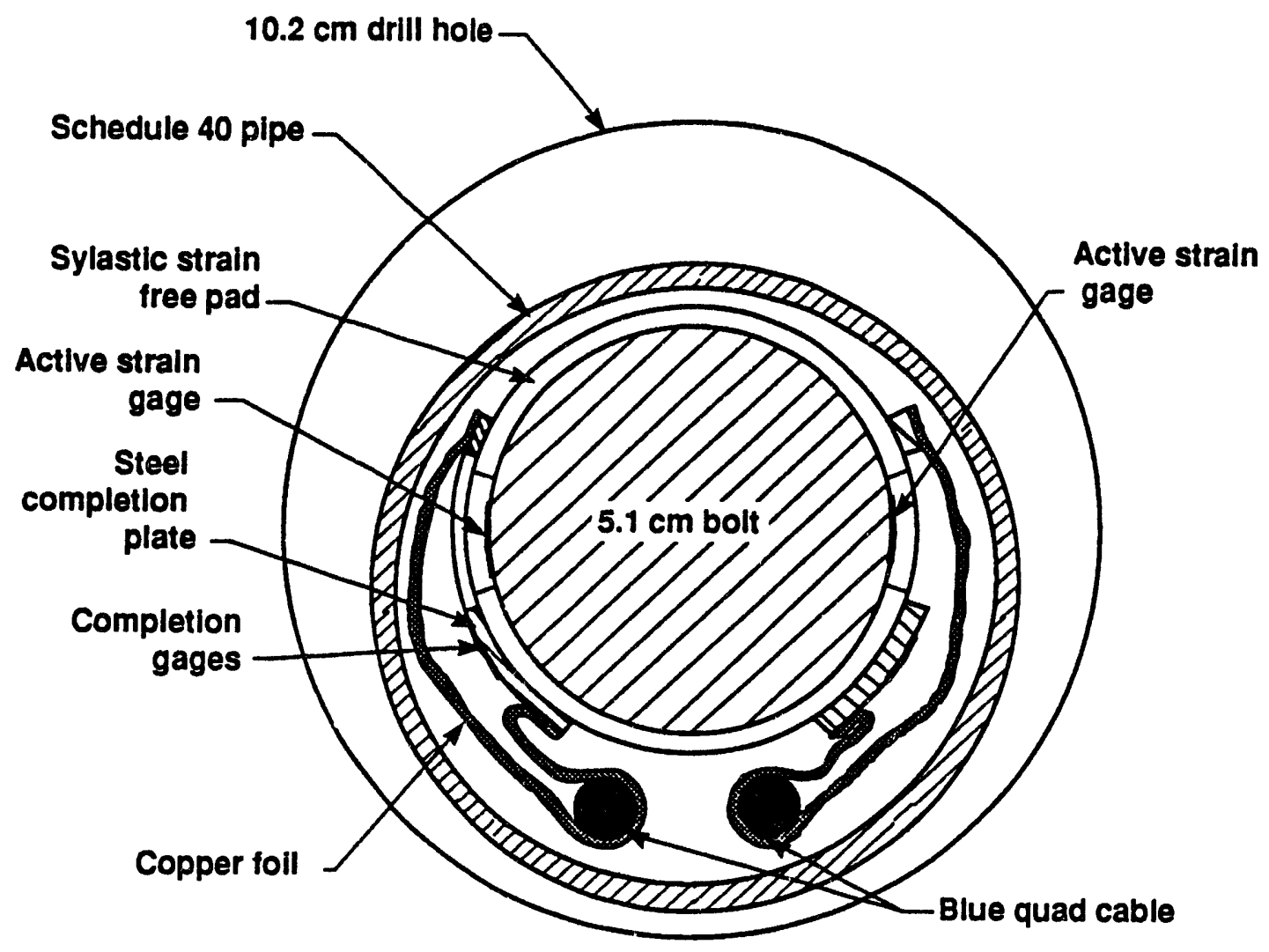

Cross-Section

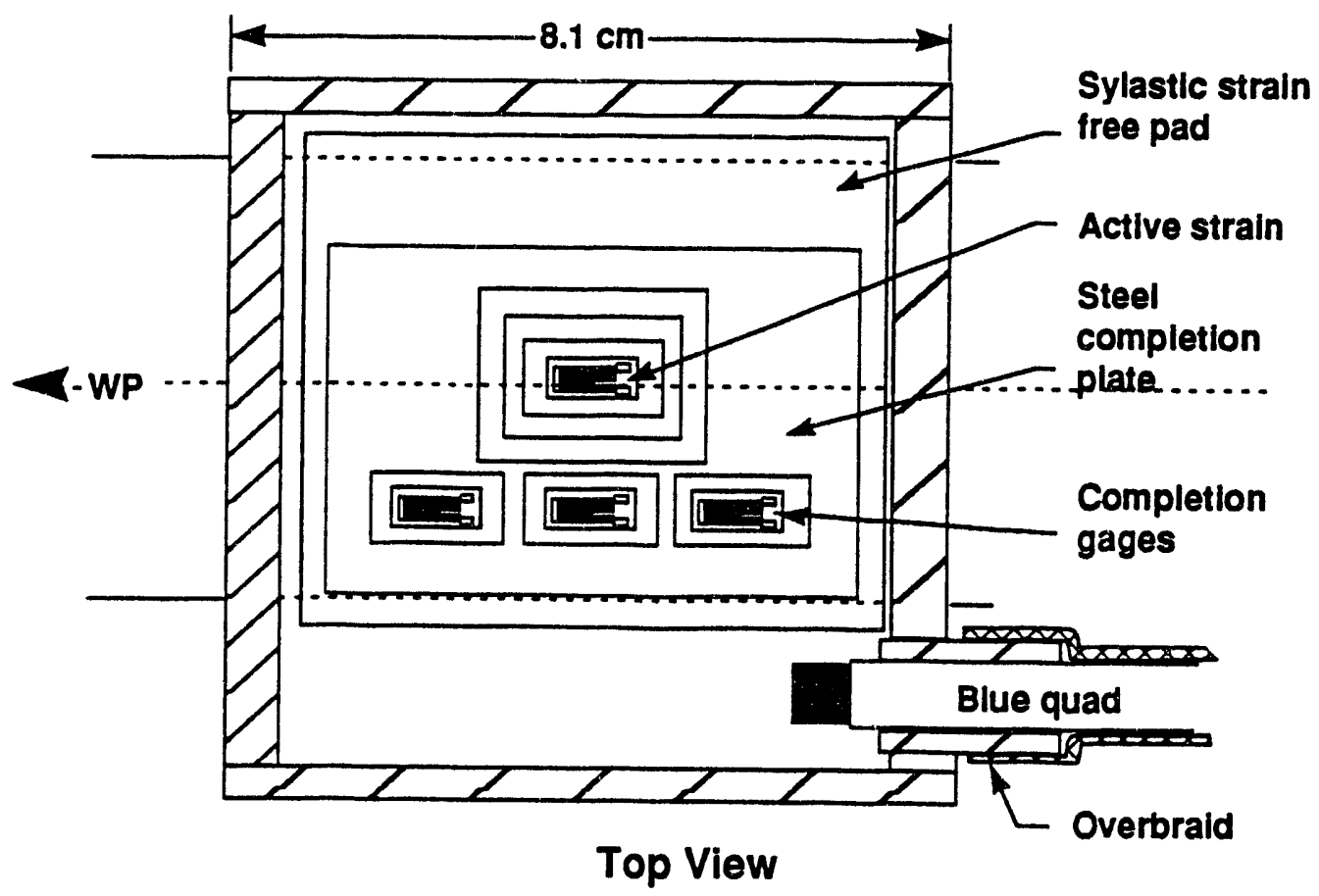

Figure 4-5: Design of gage mounting on center bolt. 


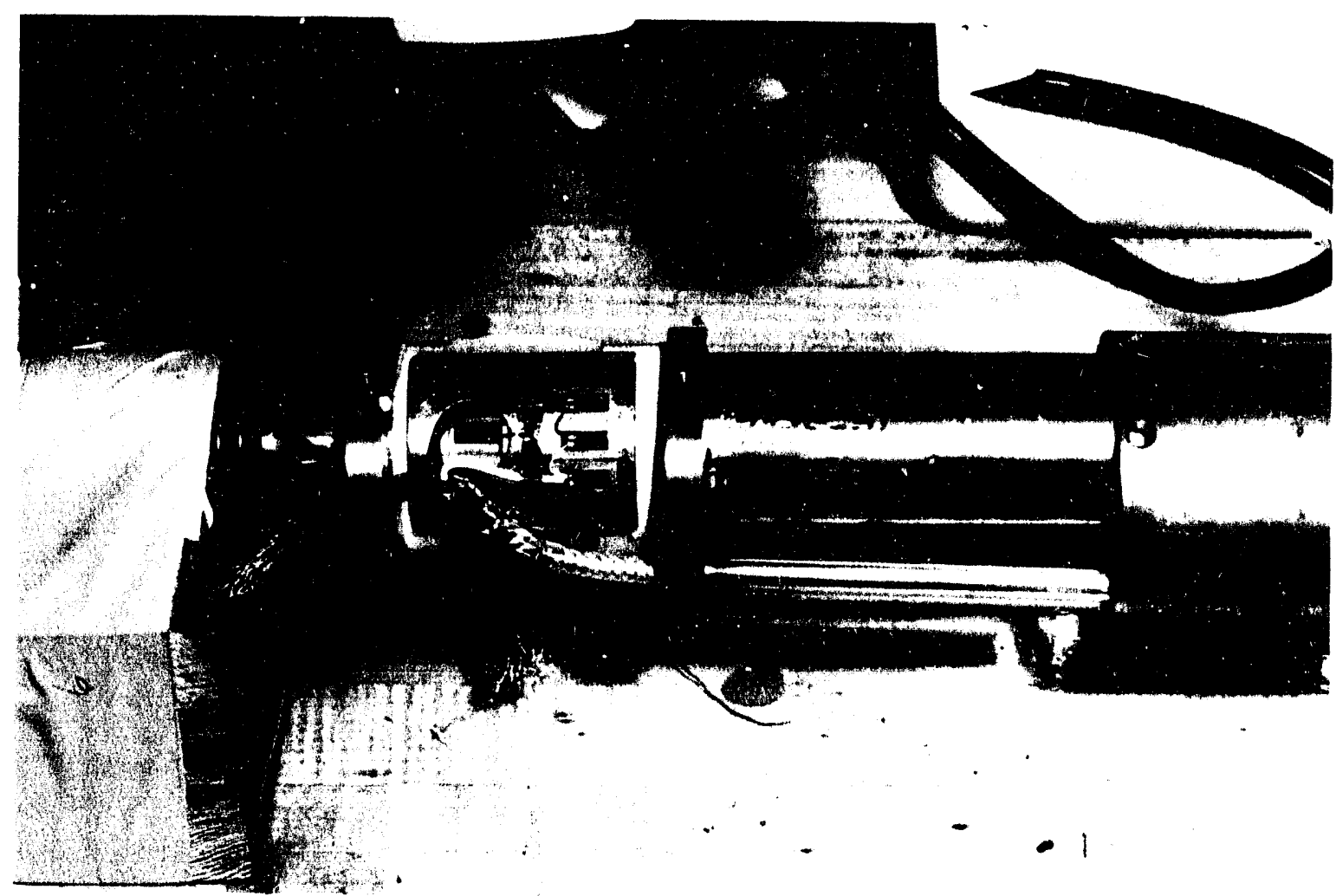

Figure 4-6: Close-up of gage station on center bolt.

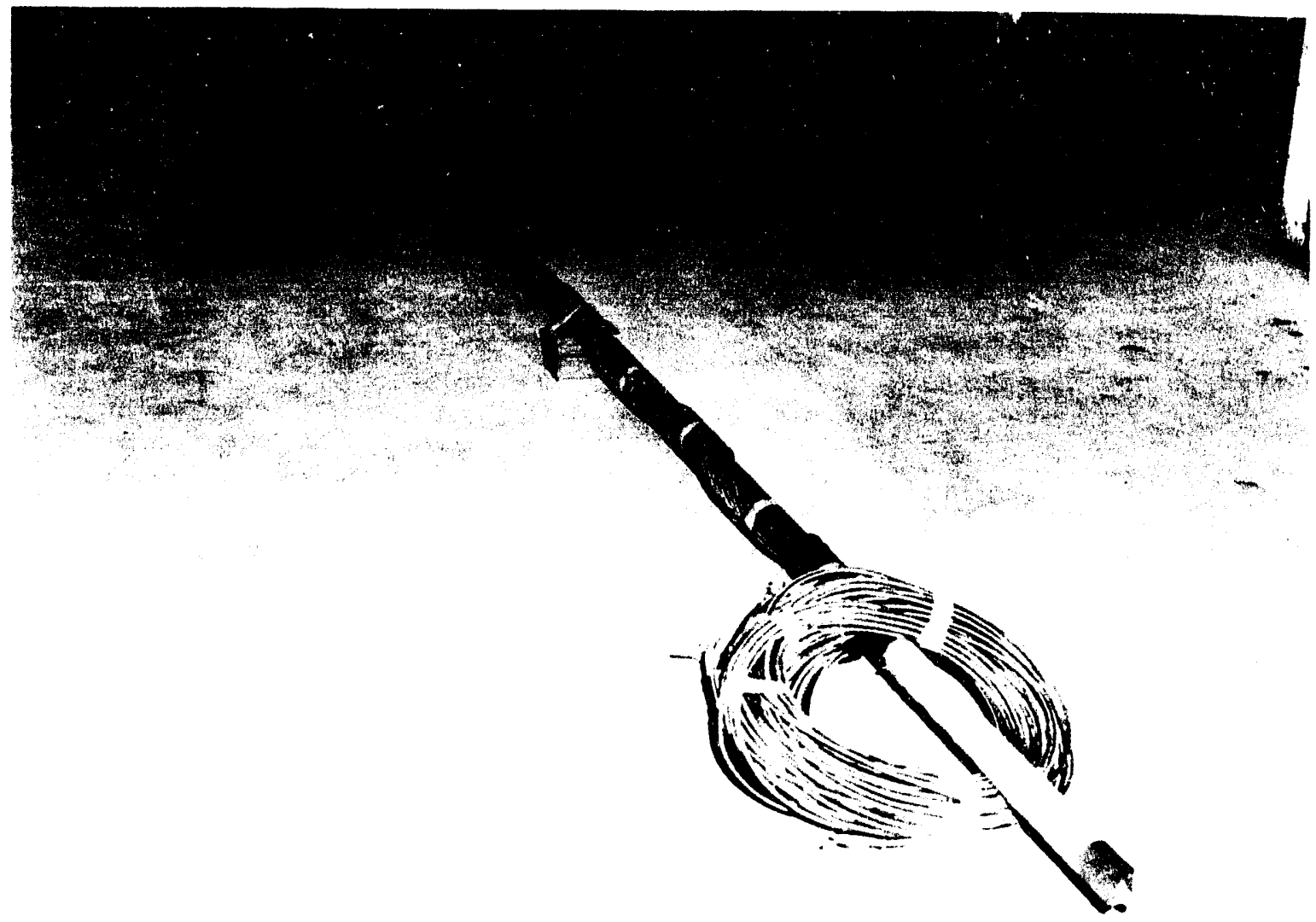

Figure 4-7: Instrumented center bolt; drift-side bolt thread is protected by tape. 
Two locations on the upper left corner bolt (facing the plate) were instrumented with one longitudinal strain gage each. The first gage (7200) was $0.517 \mathrm{~m}$ and the second (7205) was $4.350 \mathrm{~m}$ from the WP end of the bolt. The first gage was $0.459 \mathrm{~m}$ behind the back of the plate. The second gage was approximately in the center of the rock pillar. That corner bolt also had a load washer installed at the drift-side end (7605).

\subsubsection{Other Gages}

The plate and bolt gages represented 14 of the 20 channels. In addition, two toadstools were cemented in the rock face, protruding $2.5 \mathrm{~cm}$ so as to be half-way between the back of the liner plate and the rock, i. e. half-way within the grout thickness. They are clearly seen in Figures 3-4 and 3-6. Also, three FCP's were installed after the liner plate had been mounted to the cavity wall and its back grouted. They show on Figures 3-10 and 3-14. The pillar accelerometer was installed last, about 4 metres into the rock.

\subsection{DATA ACQUISITION}

\subsubsection{SANDUS}

The SANDUS (SANdia Digital Unde. ground System) is a digital data acquisition system which accepts up to 128 different analog data records. It is capable of conditioning, amplifying, digitizing, and storing these data within the system. The analog signal full-scale deviation ranges may be from $1 \mathrm{mV}$ to $10 \mathrm{~V}$ in amplitude, and from DC to $100 \mathrm{KHz}$ in frequency, for the low-frequency modules. This setting gives an accuracy of $0.024 \%$. A higher frequency module (DC to $10 \mathrm{MHz})$ provides less amplitude range $(8 \mathrm{mV}$ to $4 \mathrm{~V})$ and less accuracy $(0.39 \%)$. The low-frequency module was used. Each signal entering a SANDUS has its own dedicated signal conditioner, amplifier, and data module. The data modules contain the presample filters, sample rate control (up to 50 million samples per second), trigger controls, analog to digital converters, and internal memories. After each signal is digitized, it is sent to digital tape recorders and CMOS memories in Area $12 \mathrm{camp}$, for recording and processing. A SANDUS may also be controlled remotely, as well as manually and automatically. 
The SANDUS system is designed to take simultaneous samples on all channels that are operated at the same sampling rate. This provides a means of directly comparing gages of similar experiments, and accurately time-tagging data samples. All but one of the CONVEX data channels were digitized underground in P-tunnel by SANDUS 505, and were sent to Sandia's building 12-909 for storage on memory channels. The thermocouple channel was a real time channel which was recorded for over 4 hours.

\subsubsection{Installed Gage System Summary}

Table 4-2 summarizes the installation and data acquisition parameters for the 20 CONVEX liner gages connected to SANDUS. It shows the gage identification number, the corresponding channel number, the gage location, the 1-line drawing number describing the gages connection, the sampling rate, and the total recording time

With particular reference to recording time the following is noted:

- regarding the plate strain gages, the left-hand set (7110 and 7115$)$ was recorded at a sampling rate of 10 microseconds for nearly 80 milliseconds. This allowed collecting highly time-resolved data early in the response of the plate where higher frequency dynamic data could be expected. The right-hand set $(7100$ and 7105) was recorded on sample rate switching channels. The second sampling rate was 1.28 milliseconds. The total recording window was 4.8 seconds. This allowed obtaining long term data, after the dynamic responses were damped out, to determine the changes in the preload and the thermal response of the plate if applicable.

- on the center bolt, the first set of strain gages (7210 and 7215) was recorded at a sampling rate of 10 microseconds to collect highly time-resolved data. The second set (7250 and 7255) was recorded on sample rate switching channels to collect long term data.

Whenever possible, current-viewing resistors (CVR's) were used to indicate the state-of-health of an experimental circuit, typically a bridge circuit. A reading across a CVR that is out of calibration, most often zero or infinity, indicates a nonfunctioning circuit. Data read by the PC associated transducer must be dismissed at the time of CVR failure. 
Table 4-2: $\quad$ Summary of Characteristics for the Installed Gage System

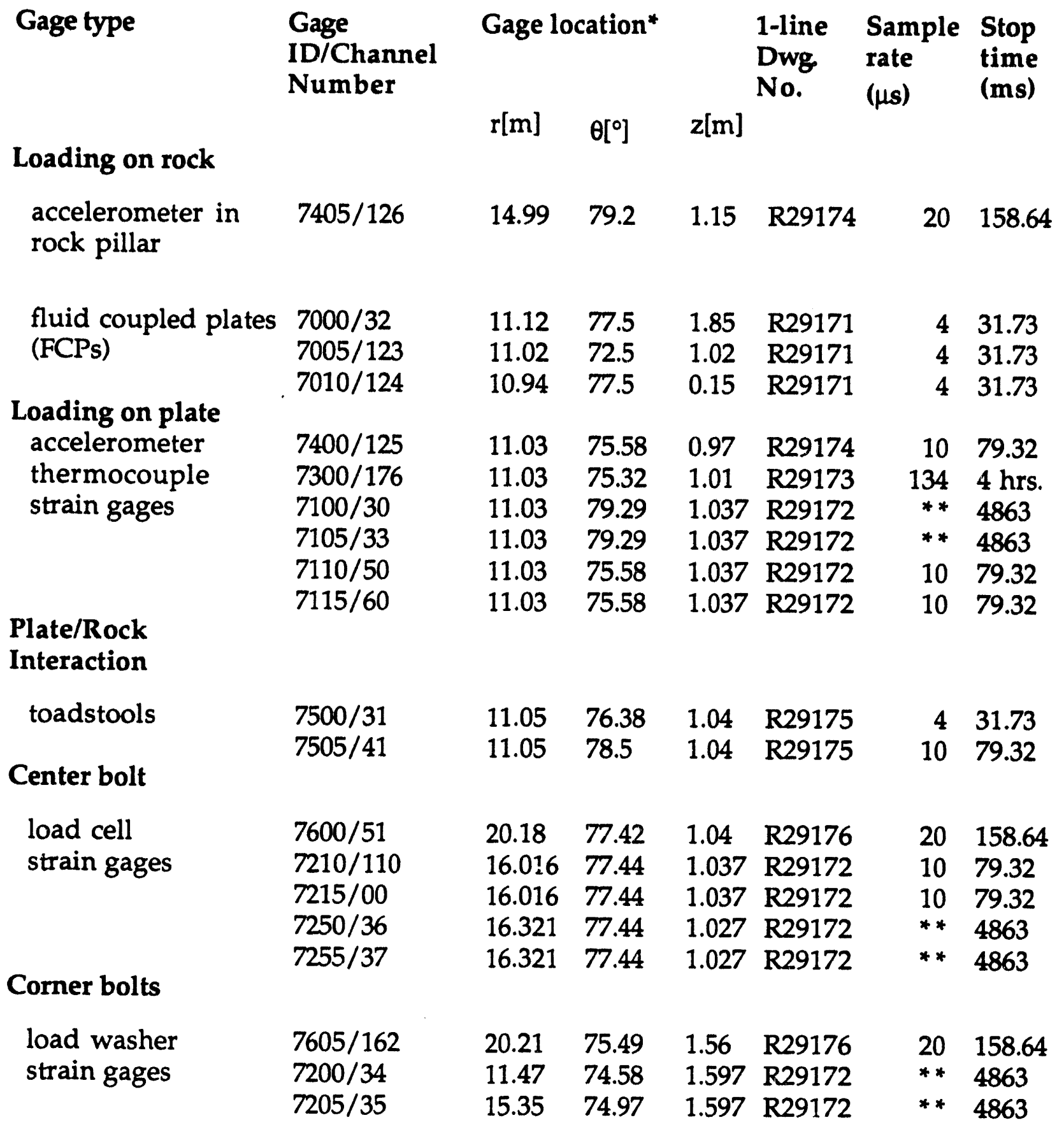

* Locations are referenced to surface ground zero on the cavity floor.

** Sample rate switched: $20 \mu$ s steps for $83.9 \mathrm{~ms}$, then $1280 \mu$ s steps for $4779 \mathrm{~ms}$. 


\section{SECTION 5}

\section{THERMAL MODELING}

\subsection{INTRODUCTION}

The main purpose of the thermal modeling was to estimate the temperature to which the various gages would be subjected, so as to evaluate their duration of survival, for recording purpose. The calculations also would determine whether thermal corrections were needed on strain records in the dynamic phase. Temperatures were sought at the rock wall, i.e. on the outside face of the plate, at the back of the plate, in the grout behind the plate (toadstool locations), and along the bolts.

The finite element program TOPAZ [14] was used to perform four analyses, in axisymmetric geometry (Figure 5-1):

- an 11-m radius cylindrical, unlined, rock cavity, 9-m thick. The mesh was 1-zone wide and 94-zones deep. Melting of the rock was allowed

- an $11-\mathrm{m}$ radius, $2.54-\mathrm{cm}$ thick, cylindrical steel liner backed by $5.08-\mathrm{cm}$ of grout, and $9 \mathrm{~m}$ of rock. This model was 1-zone wide and 94-zones deep. No rock melting was allowed.

- a 9-m long center bolt, not grouted. The mesh was 1-zone wide and 95-zone deep.

- a 9-m long corner bolt, with grout and rock surrounding it to a radial distance of $20-\mathrm{cm}$. The grid was 3-zones wide and 99-zones deep.

The same thermal pulse was specified on the cavity side for each geometry, and the mesh boundaries were made adiabatic.

\subsection{THERMAL PROPERTIES}

The physical and thermal properties of the plate and bolt steels were known from reference material $[15,16]$. 

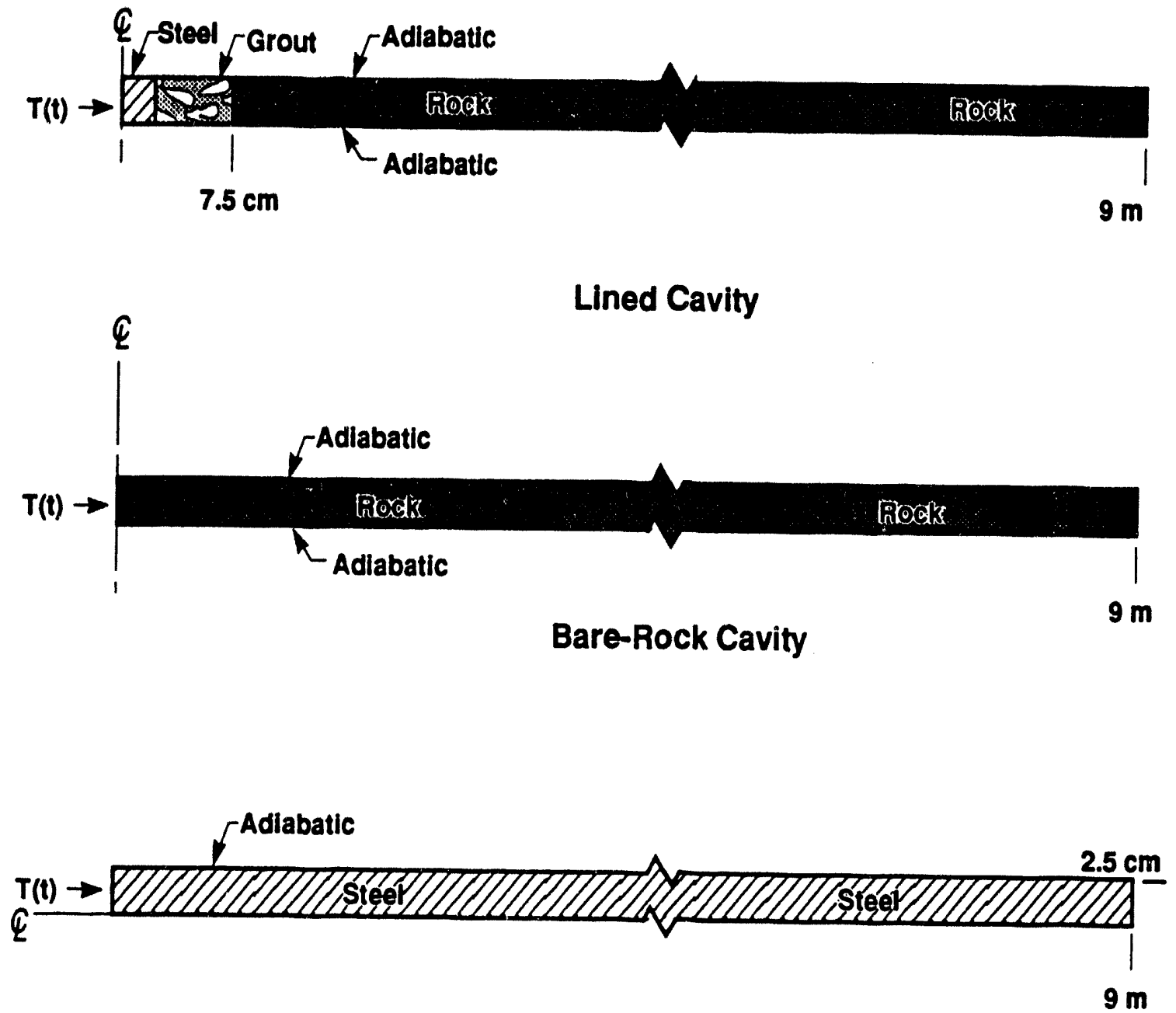

Center Bolt

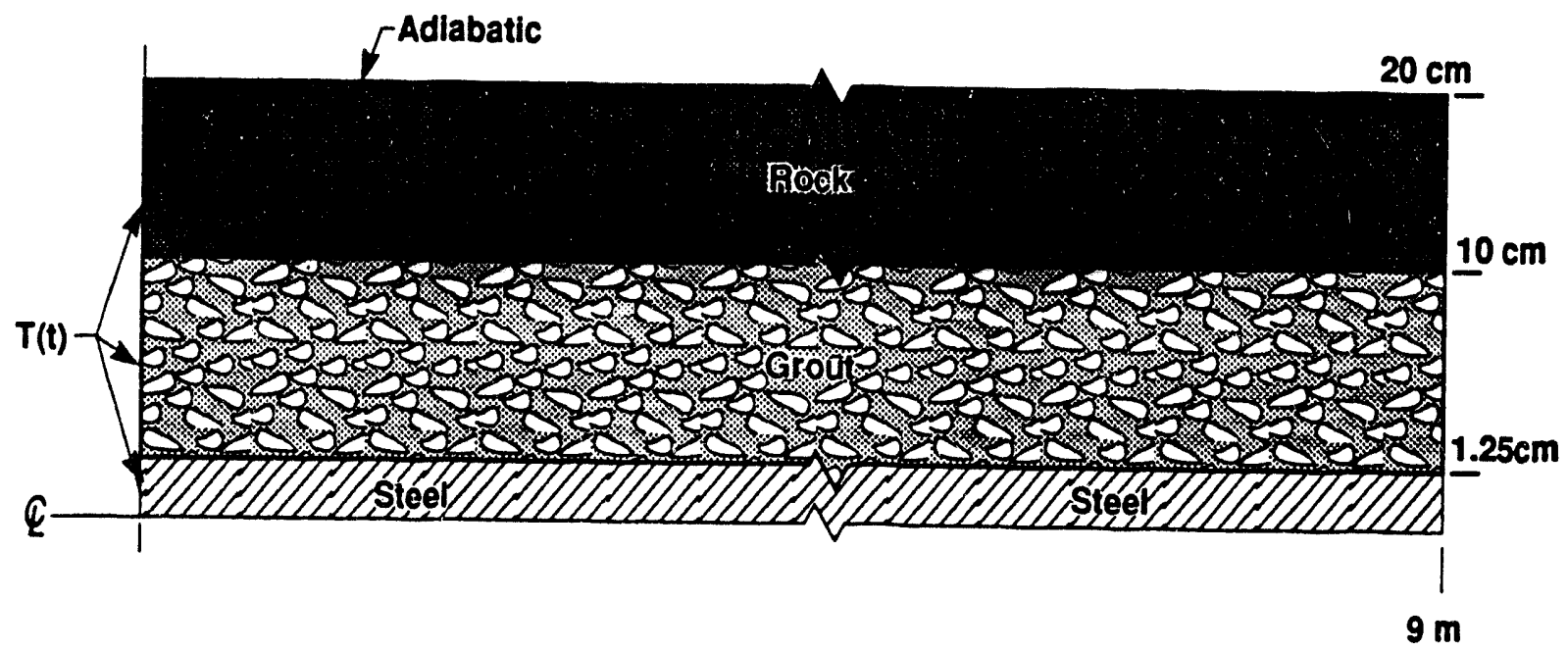

Grouted Corner Bolt

Figure 5-1: Geometries for thermal analyses. 
In the absence of thermal testing for the rock and grout, the thermal properties of the tuff were selected from a survey of igneous rocks in general [17-21], and NTS tuffs in particular $[22,23]$. Without actual data, the properties were given constant values; but, the authors are aware that rock properties such as specific heat and thermal conductivity vary with temperature. The grout was given the same properties as the rock.

Table 5-1: $\quad$ Properties of steel, grout, and rock for thermal calculations

\begin{tabular}{|c|c|c|c|c|}
\hline $\begin{array}{l}\text { Density } \\
\left(\mathrm{g} / \mathrm{cm}^{3}\right)\end{array}$ & $\begin{array}{l}\text { Heat } \\
\text { capacity } \\
\text { (cal/g. }{ }^{\circ} \mathrm{c} \text { ) }\end{array}$ & $\begin{array}{l}\text { Thermal } \\
\text { conductivity } \\
\text { (cal/s.cm. }{ }^{\circ} \mathrm{c} \text { ) }\end{array}$ & $\begin{array}{l}\text { Melting } \\
\text { Temperature } \\
\quad\left({ }^{\circ} \mathrm{C}\right)\end{array}$ & $\begin{array}{l}\text { Latent Heat } \\
\text { of Fusion } \\
\text { (cal/g) }\end{array}$ \\
\hline
\end{tabular}

\begin{tabular}{lrrrrr}
\hline Steel & 7.85 & 0.116 & 0.121 & $\mathrm{n} / \mathrm{a}$ & $\mathrm{n} / \mathrm{a}$ \\
Rock, or & 1.75 & 0.250 & $3.58 \mathrm{E}-3$ & 1000 & 80 \\
Grout & & & & &
\end{tabular}

\subsection{RESULTS OF THERMAL CALCULATIONS}

The profiles of increase in temperature versus time are shown in Figure 5-2 through 5-6. The thermal pulse from the cavity is curve $A$; it is the rock surface temperature history and it is the same in all cases. This boundary condition was obtained from calculations made by Sandia for the MINI-JADE cavity event, which was comparable to DIAMOND FORTUNE. Some notable features of the results are:

- Unlined cavity: The peak increase in rock temperature at a depth of $1.27-\mathrm{cm}$ does not exceed $300^{\circ} \mathrm{C}$, and at a depth of $7.62-\mathrm{cm}$ it barely reaches $100^{\circ} \mathrm{C}$ (Figure 5-2). If the rock were wet, water would probably not boil-off beyond $10-\mathrm{cm}$ into the rock, at the altitude of the test chamber

- Steel-lined cavity: the location of concern is the steel-grout interface (steel plate back face), where the strain gages are mounted.Assuming that the pretest cavity and plate temperatures do not exceed $30^{\circ} \mathrm{C}$, and knowing that the strain gages will function up to $93^{\circ} \mathrm{C}$ (Table 4-1), the allowable $\Delta \mathrm{T}$ on the back of the plate is about $63^{\circ} \mathrm{C}$. As shown in Figure 5-3, curve $\mathrm{C}$, such a 
temperature increase will not occur for at least 2 seconds. For a time less than $0.2 \mathrm{sec}$ the $\Delta \mathrm{T}$ is less than $1^{\circ} \mathrm{C}$.

- Center bolt: here, the increase in temperature is less than $1^{\circ} \mathrm{c}$ for over $1 \mathrm{~s}$, at a depth of 5-cm (Figure 5-4). The strain gages on the center bolt were more than 4-m away from the cavity.

- Corner bolts: the strain gages are at the steel-grout contact. Figure 5-6 shows that a gage $20-\mathrm{cm}$ deep into the rock (curve D) would see no more than $40^{\circ} \mathrm{c}$. The closest bolt strain gages to the cavity were at a depth of 47-cm (Table 4-2). It is also clear that such a gage would sense less than a $1^{\circ} \mathrm{C}$ temperature increase for several thousand seconds.

We conclude that there is no need for corrections due to thermal strains in the strain gages, during the dynamic phase.

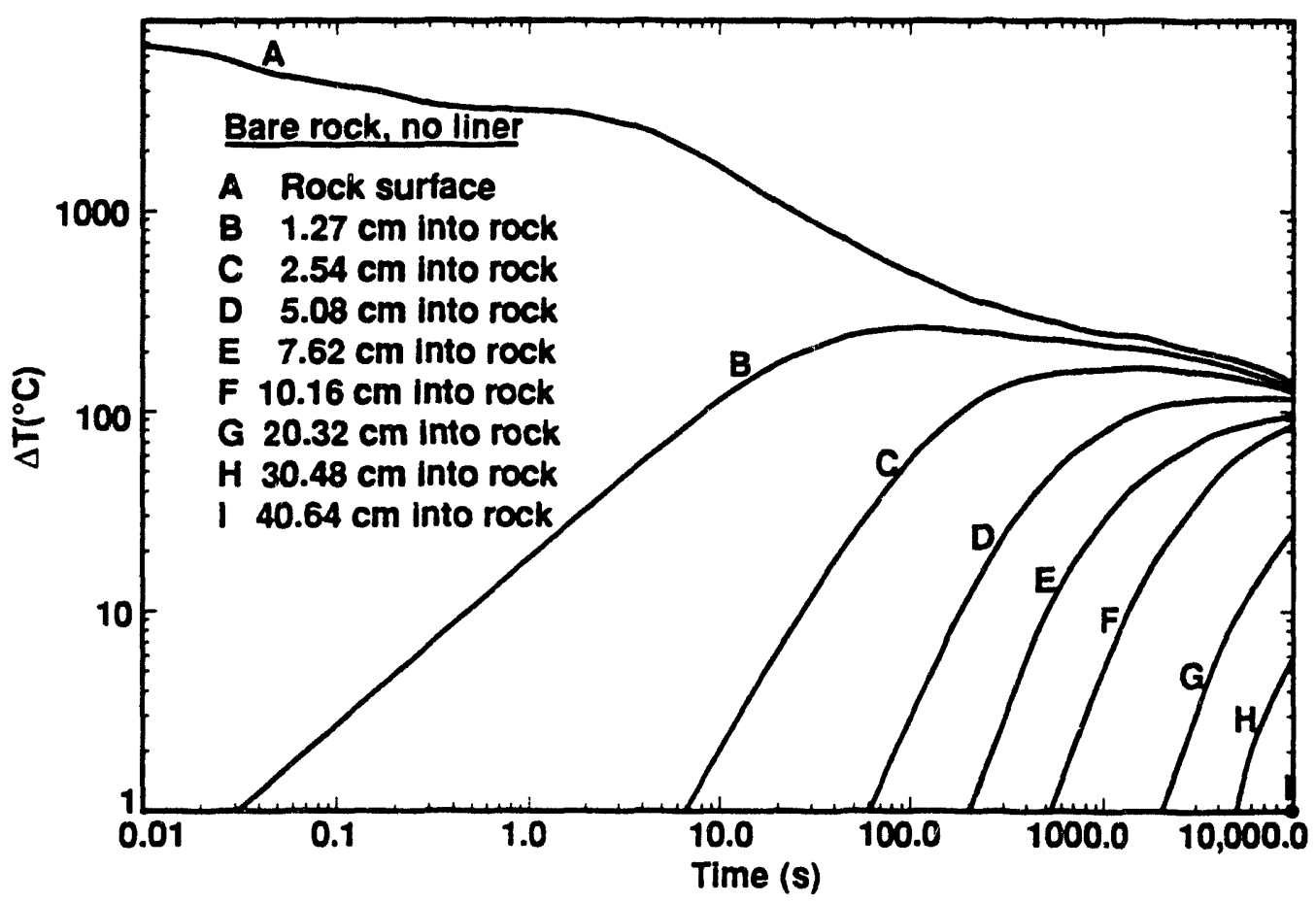

Figure 5-2: Calculated temperature histories, bare rock cavity. 


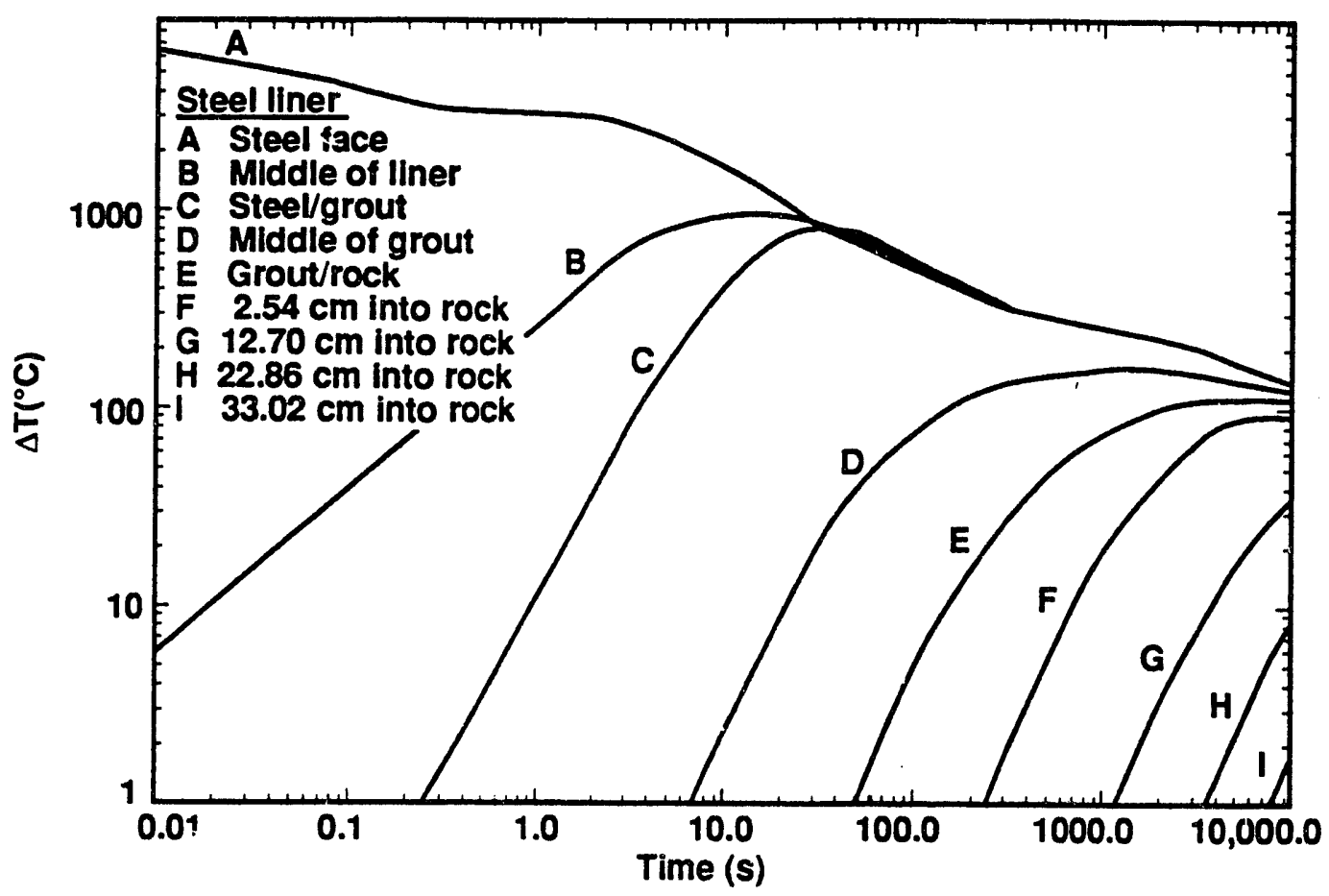

Figure 5-3: Calculated temperature histories, steel lined cavity.

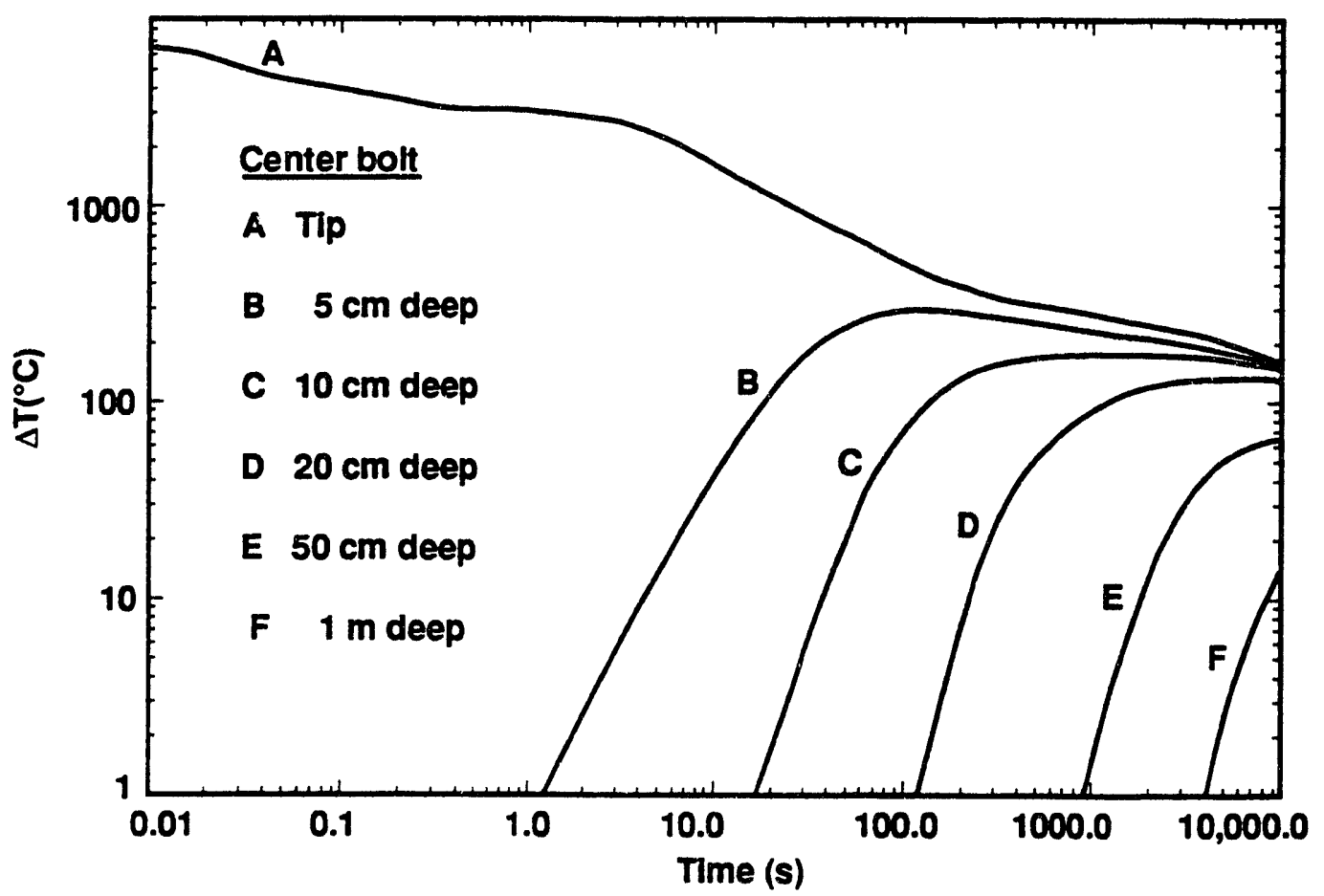

Figure 5-4: Calculated temperature histories, center bolt. 


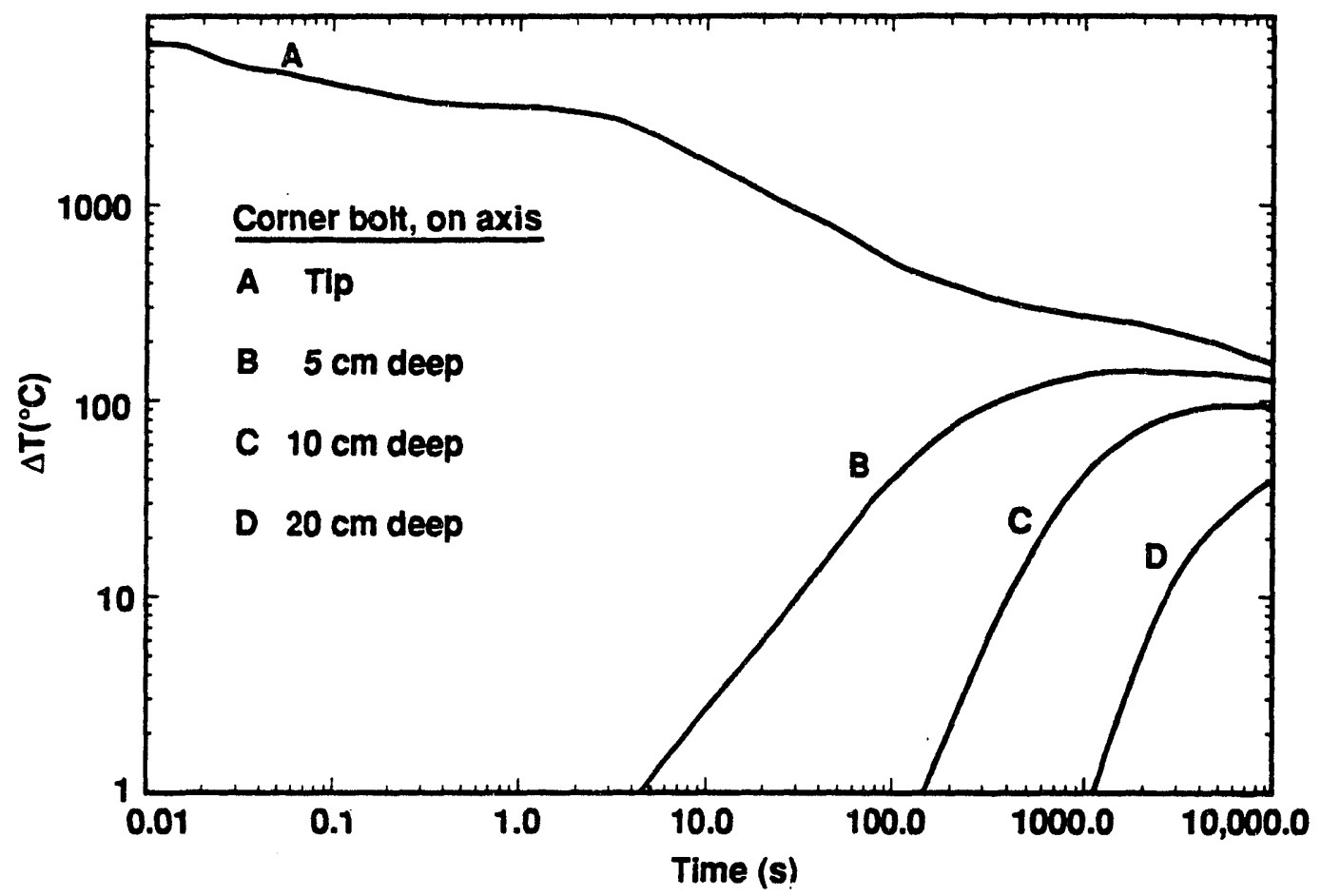

Figure 5-5: Calculated temperature histories, corner bolt on axis.

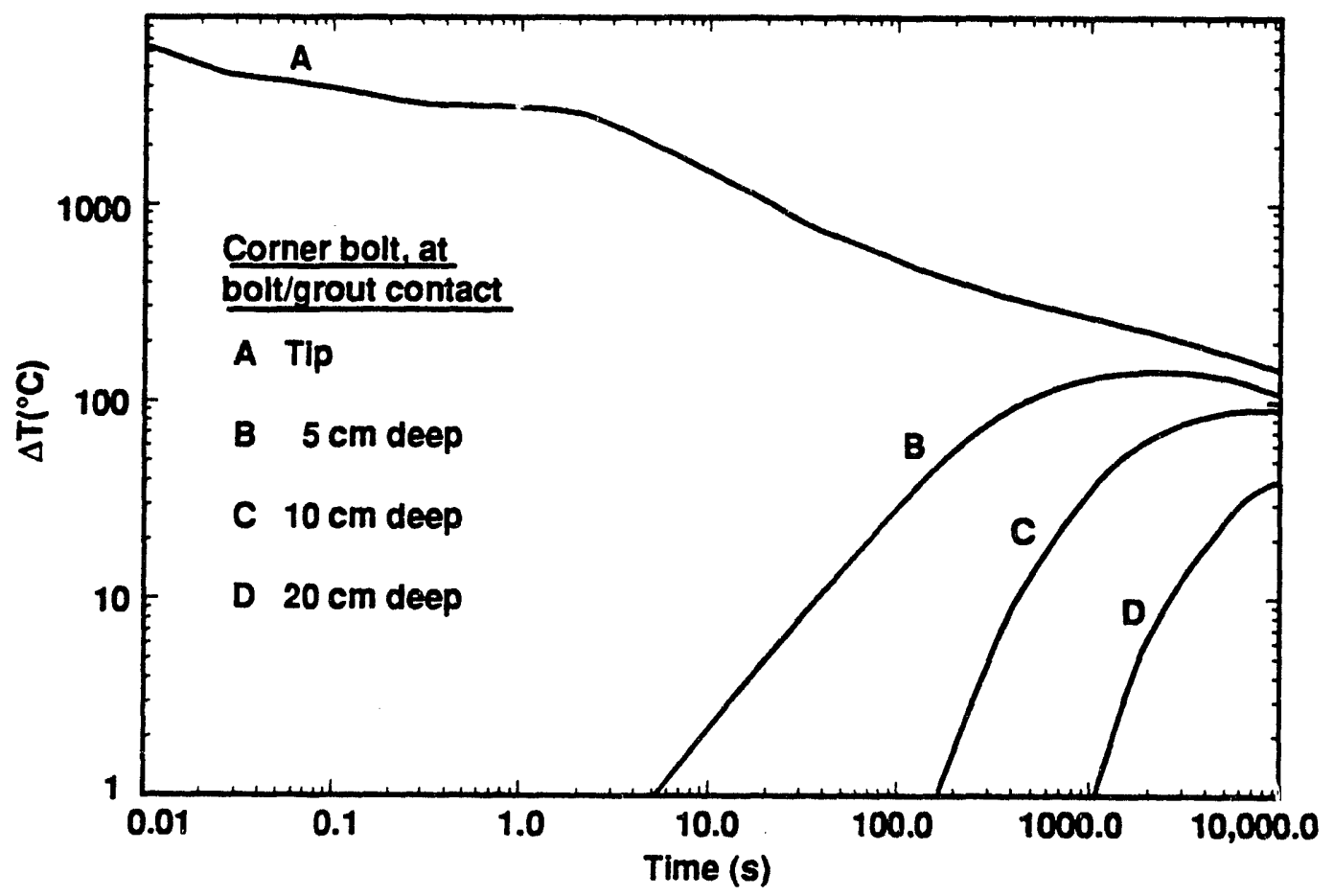

Figure 5-6: Calculated temperature histories, corner bolt at bolt/grout contact. 


\section{SECTION 6}

\section{MECHANICAL MODELING}

\subsection{OVERVIEW}

The mechanical modeling effort consisted of performing dynamic scoping calculations of one- and two-dimensional axisymmetric configurations, followed by three-dimensional static and dynamic simulations of the steel liner/bolt/rock system. The one- and two-dimensional calculations were performed pre-test with the code KDYNA [24], a specialized version of DYNA2D for geomechanics problems. Because no linkage was available between static and dynamic twodimensional codes, these calculations focused only on the dynamic response of limited liner/centerbolt/rock configurations subjected to various blast wave pressure loadings on the front face of the plate and bolt. They addressed numerical aspects, such as zoning and artificial viscosity requirements, along with a survey of material model effects that would be needed for the threedimensional modeling. These calculations provided insight into the response of the system that was very helpful in developing a three-dimensional model. The three-dimensional simulations were performed pre- and post-test, using static and dynamic finite-element codes developed a LLNL. The approach consisted of first using NIKE3D [25], to simulate the static equilibrium state due to pre-test bolt tensioning. This state was then mapped into DYNA3D [26], as initial conditions for the dynamic response calculations. Our discussion, herein, will focus only on the post-test three-dimensional simulations. The purpose of the 3$D$ calculations was to validate 3-D models for the study of other CONVEX options, in addition to analyzing the response of the actual liner add-on.

The pre-test calculations were performed to guide instrument choice, location and recording ranges, to set the tensioning of the bolts, and generally, to produce confidence that the liner system would survive the environment and remain operational. The assumed cavity wall loading was based on LANL and S-Cubed cavity flow field calculations and results of the MILLYARD and MINI JADE cavity events which were similar in geometry and loading to DIAMOND FORTUNE. The post-test calculations were performed with a revised estimate of the actual cavity pressure history at the liner plate, taking into account the toadstool data. 


\subsection{THREE-DIMENSIONAL MODEL}

Views of the three-dimensional model are given in Figures 6-1 and 6-2, showing the upper-right quadrant of the system that extends back from the cavity face into the rock. The quadrant geometry accommodates symmetry of the experiment about the axis of the centerbolt. The model extends axially outward, 9-m, to the run-around alcove where the wall buffer plates and holding nuts for the centerbolt and cornerbolt are secured. A total of 22,706 solid-brick elements are used in the static model along with 19 slide surfaces. The DYNA3D model includes the NIKE3D model, plus 2139 additional elements and 4 slide surfaces extending the rear of the model into the grout-enclosed run-around region and beyond into the rock to a range of $50-\mathrm{m}$. Slide surfaces represent the following interfaces: steel bolt-steel plate, steel plate-buffer plate, steel plate-grout, steel boltgrout, steel bolt-rock, and rock-grout. Both the centerbolt and the cornerbolt are tied to the nuts and plates at the cavity and rear surfaces. The boundary conditions on the top and right outer rock surfaces allow no vertical and no horizontal motion, respectively. The loading function on the plate for the dynamic phase is shown in Figure 6-3.

As described in Section 2, estimates for the rock material properties required for numerical modeling were obtained from in-situ borehole-jack tests, as well as from wave speed and strength measurements on core samples from the pillar. Wave speed and strength measurements also were obtained on core samples of the HLNCC grout used behind the plate. The in-situ Young's modulus estimated from borehole jack tests and $R Q D$, shown in Figure 2-6, reflects the variation of rock quality through the pillar. The elastic properties used in the calculations are given in Table 6-1; the rock is assumed to be uniform throughout the pillar with properties representative of those near the cavity. The pore compaction and strength representations used for the rock and grout are shown in Figures 6-4 and 6-5.

Table 6-1. Best estimate of elastic and plastic material properties for CONVEX liner calculations.

\begin{tabular}{lcccll} 
& Steel Bolts & Steel Plates & Rock & Grout & Unit \\
\hline Density & 7850. & 7850. & 1400. & 1350. & $\mathrm{Mg} / \mathrm{m}^{3}$ \\
Young's Modulus & 210. & 210. & 1.70 & 4.0 & $\mathrm{GPa}$ \\
Poisson's ratio & 0.30 & 0.45 & 0.35 & & \\
Yieid stress & 760. & 250. & Figure 6.4 & Figure 6.5 & $\mathrm{MPa}$
\end{tabular}




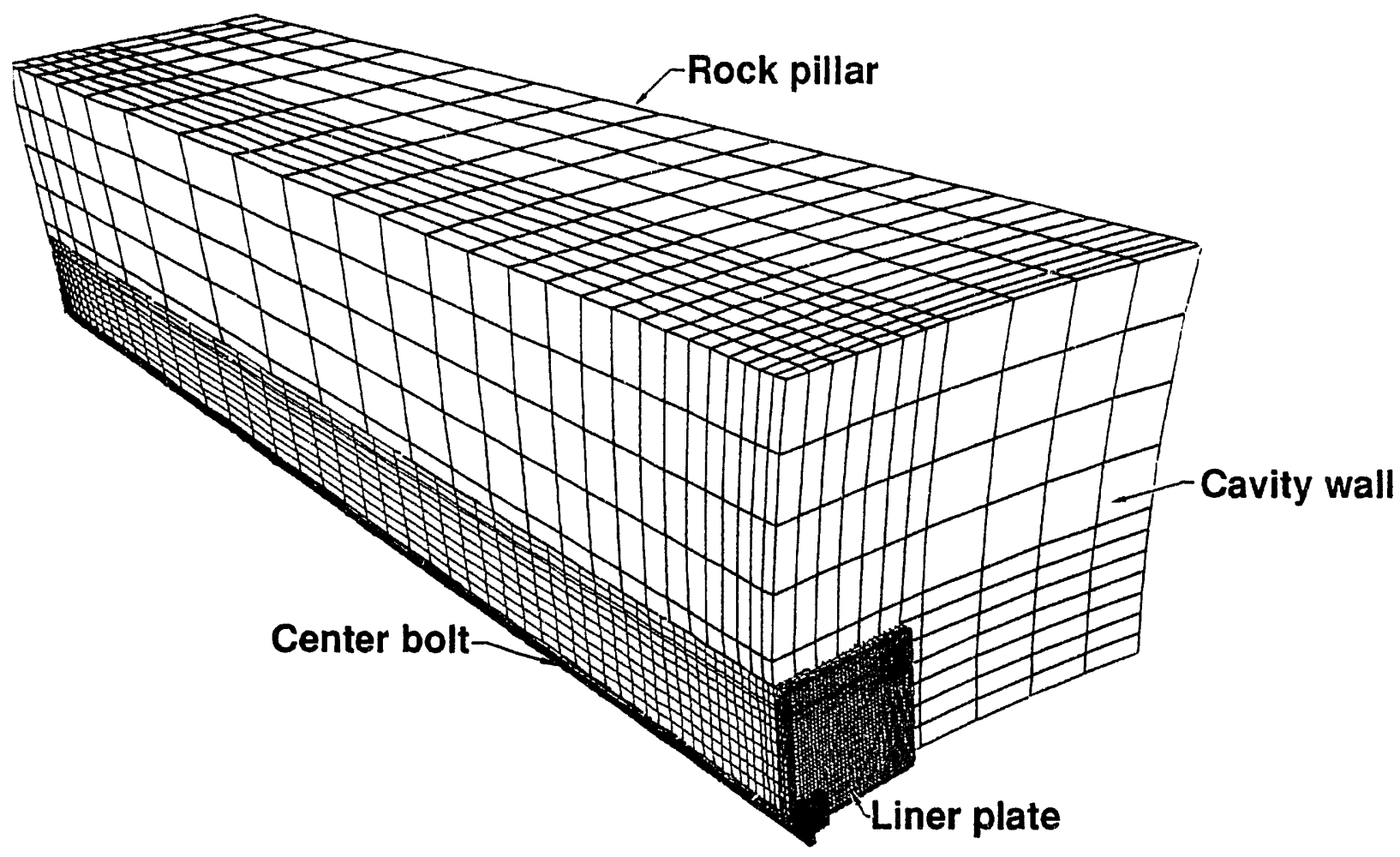

Figure 6-1: Complete model for 3-d mechanical analysis. Note the double curvature of the cavity wall.

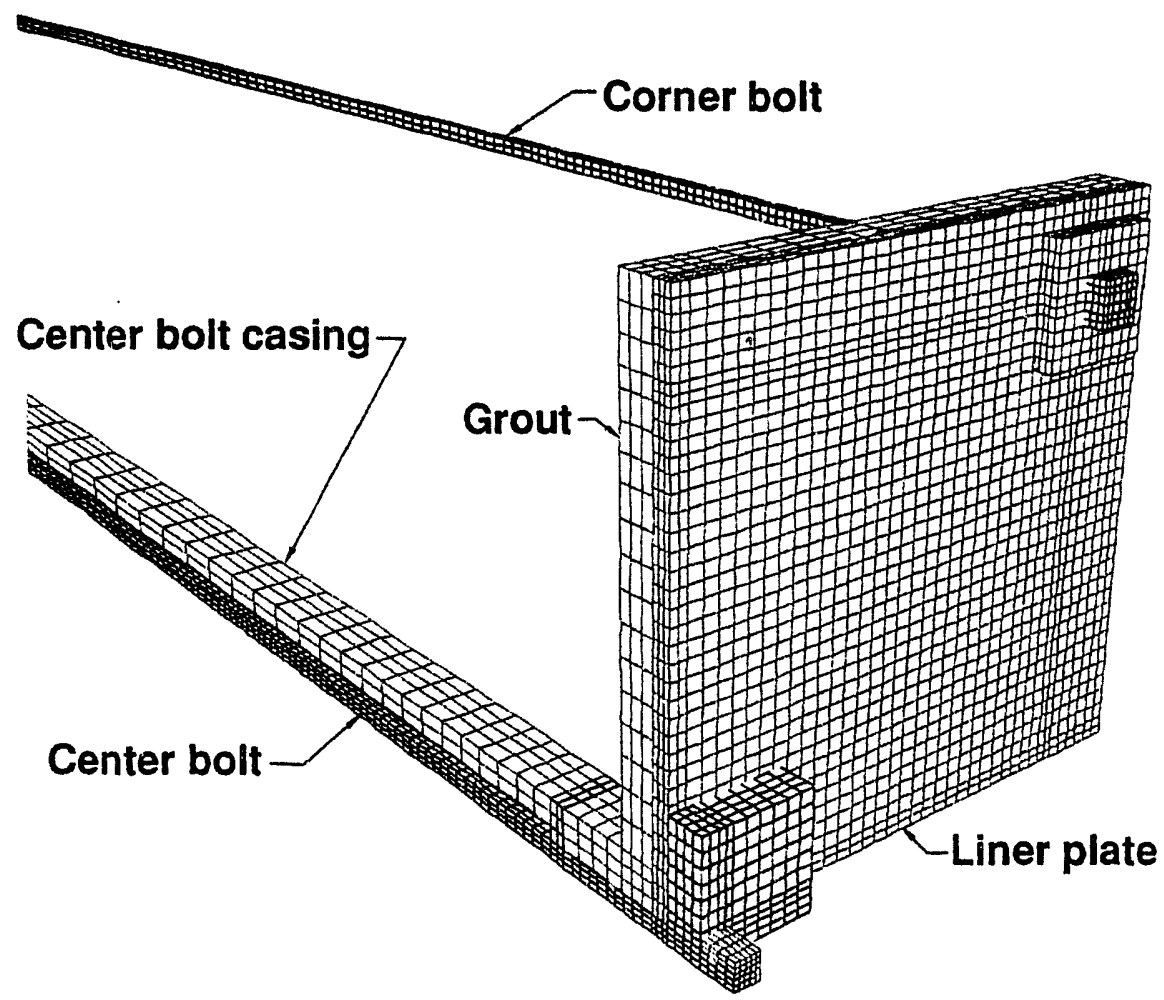

Figure 6-2: Details of model for plate, bolts, and grout layer. 


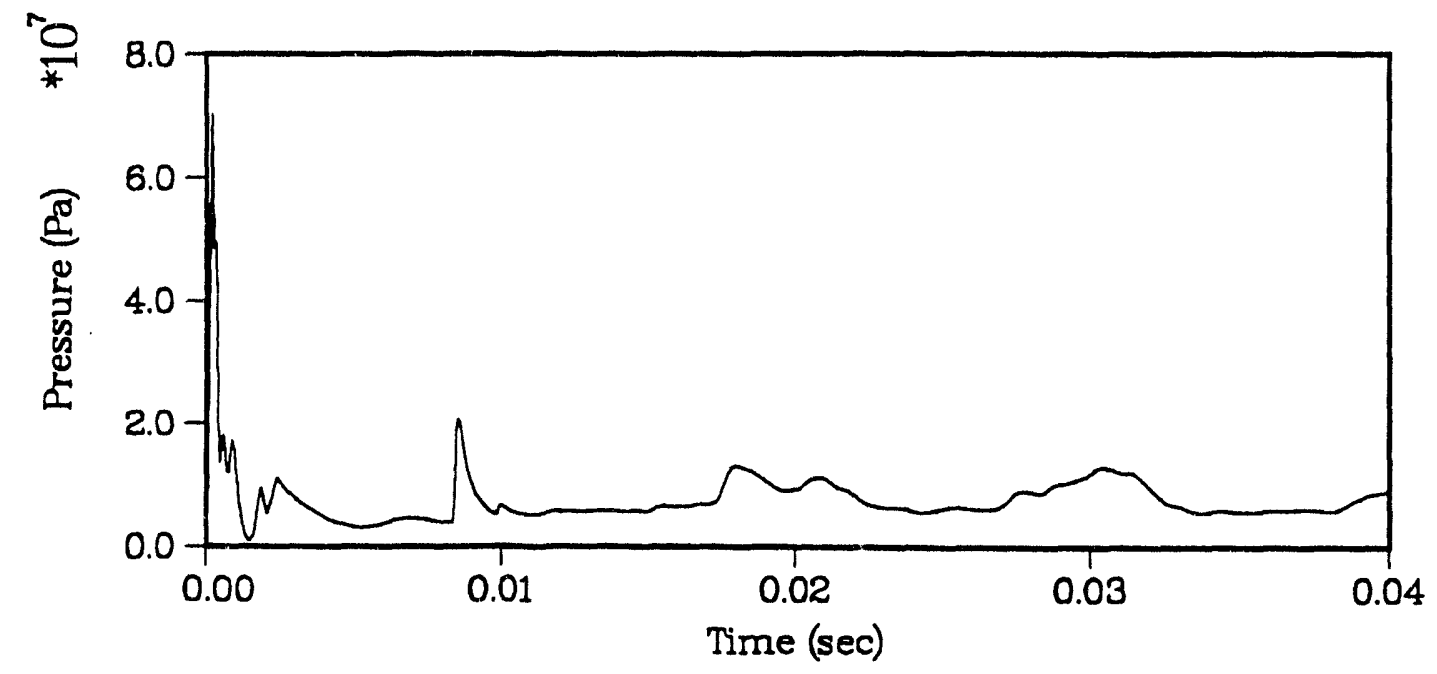

Figure 6-3: Pressure loading function on liner plate.

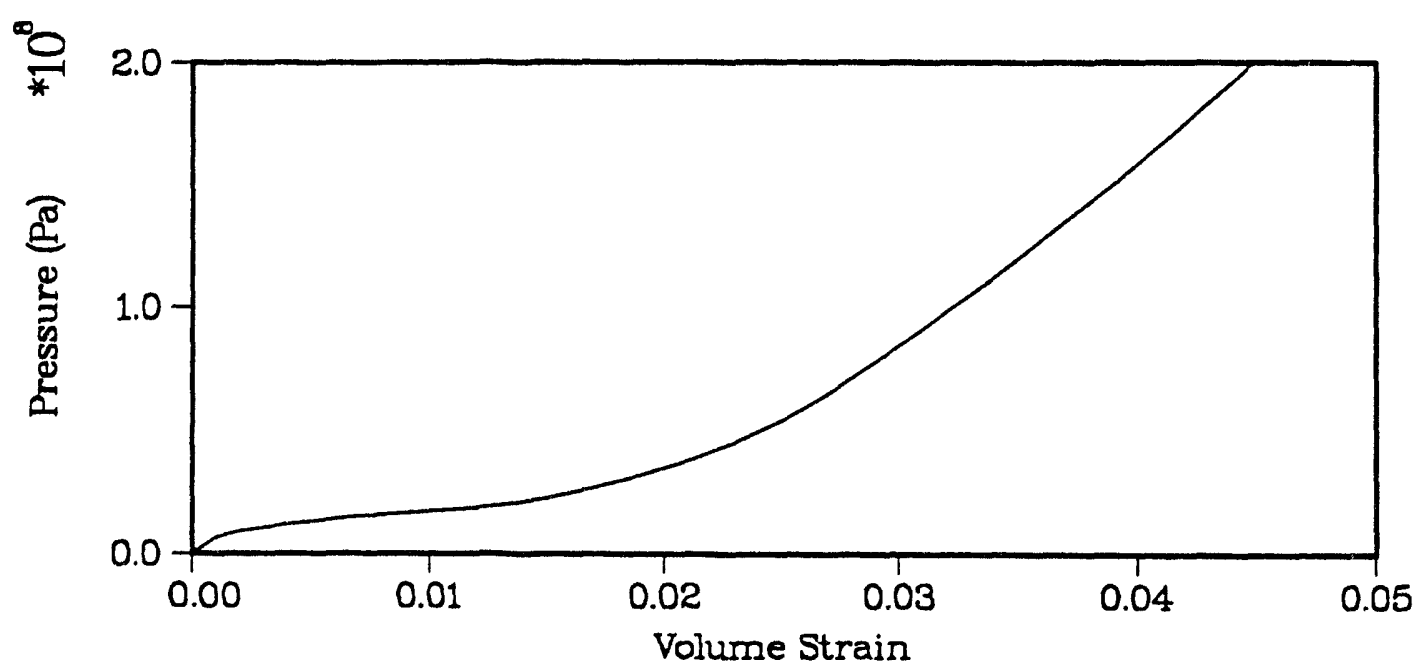

Figure 6-4: Compressibility for rock and grout, used in calculations.

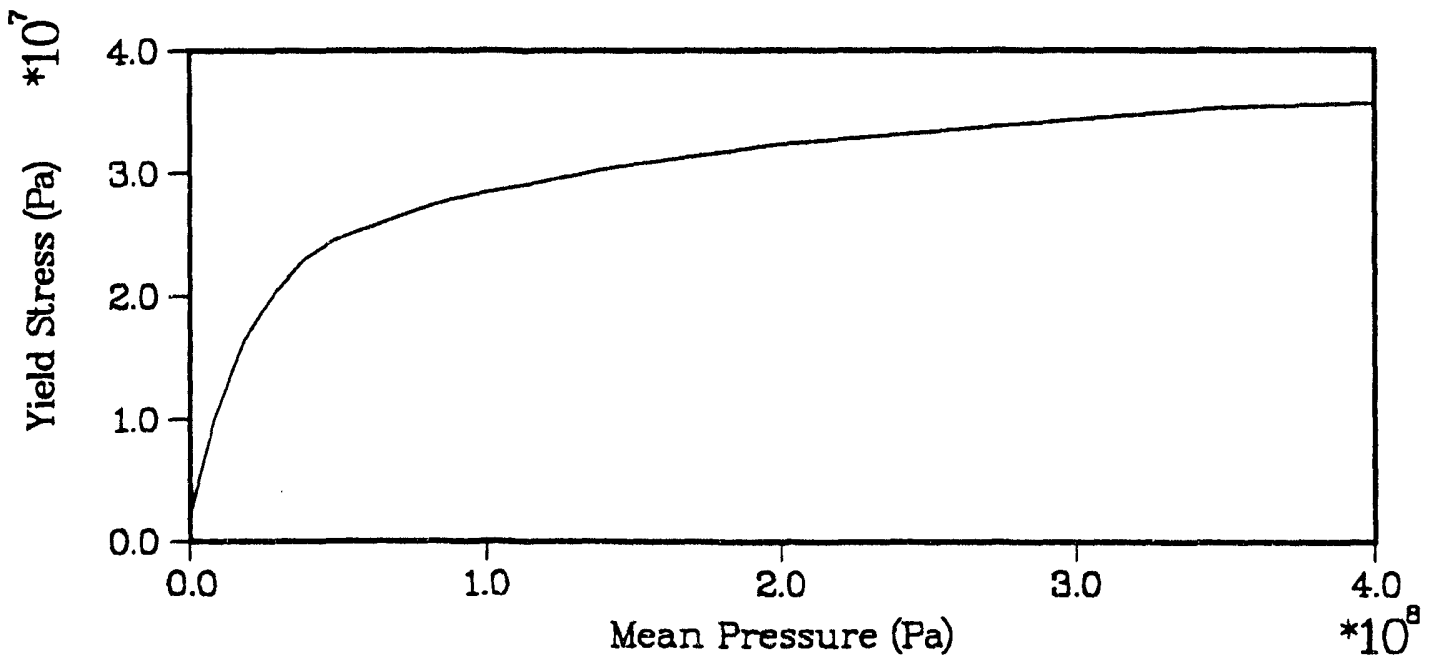

Figure 6-5: Strength behavior for rock and grout, used in calculations. 


\subsection{3-D EQUILIBRIUM CONDITION}

A thermal-elastic-plastic model was used to model the centerbolt and cornerbolt. A pseudo-thermal condition to reduce the temperature in the bolts provided the desired pre-test tension loading of $325 \mathrm{MPa}$. This thermal condition was maintained for the dynamic response simulation. The equilibrium vertical and horizontal strains on the rear surface of the plate, under pre-tensioning of the centerbolt and cornerbolts, are shown in Figures 6-6 and 6-7 respectively. Because of quadrant symmetry, horizontal and vertical strains have identical character relative to their directions. The equilibrium outward displacement calculated for the rear surface of the plate adjacent to the grout is shown in Figure 6-8. The maximum displacement is about $0.45-\mathrm{mm}$ in the elements next to the centerbolt. The stress distribution for the centerbolt and plate (Figure 6-9) indicates maximum compressive and tension axial-stress concentrations of about -300 $\mathrm{MPa}$ and $+430 \mathrm{MPa}$, respectively, in the region where the nut fastens the bolt to the plate. These stress levels are well below the elastic yield stress and the entire system is linear. Just behind the plate, at a distance of about $8.5-\mathrm{cm}$ along the length of the bolt, the stress becomes uniform with an axial tension of $325 \mathrm{MPa}$ and remains at this level thereafter until in the immediate vicinity of the runaround wall. This configuration is mapped into DYNA3D as the initial state for the dynamic response calculation. The pseudo-thermal model approach is believed to simulate the stress and strain states associated with bolt tensioning quite realistically. The same conditions would be very difficult to obtain using mechanical force or pressure prescriptions for the bolts, plate and rock exterior surfaces.

\subsection{3-D DYNAMIC RESPONSE}

The dynamic behavior of the liner/bolt/rock system is dependent on the material properties of the rock, on the boundary conditions imposed, i.e., the blast wave loading condition, and on interface conditions, i.e., how the cornerbolt-grout interface and how the nut-buffer plate-main plate interfaces are treated. In this section we will illustrate the influence of two main physical features on the response of the system. We will show how: 


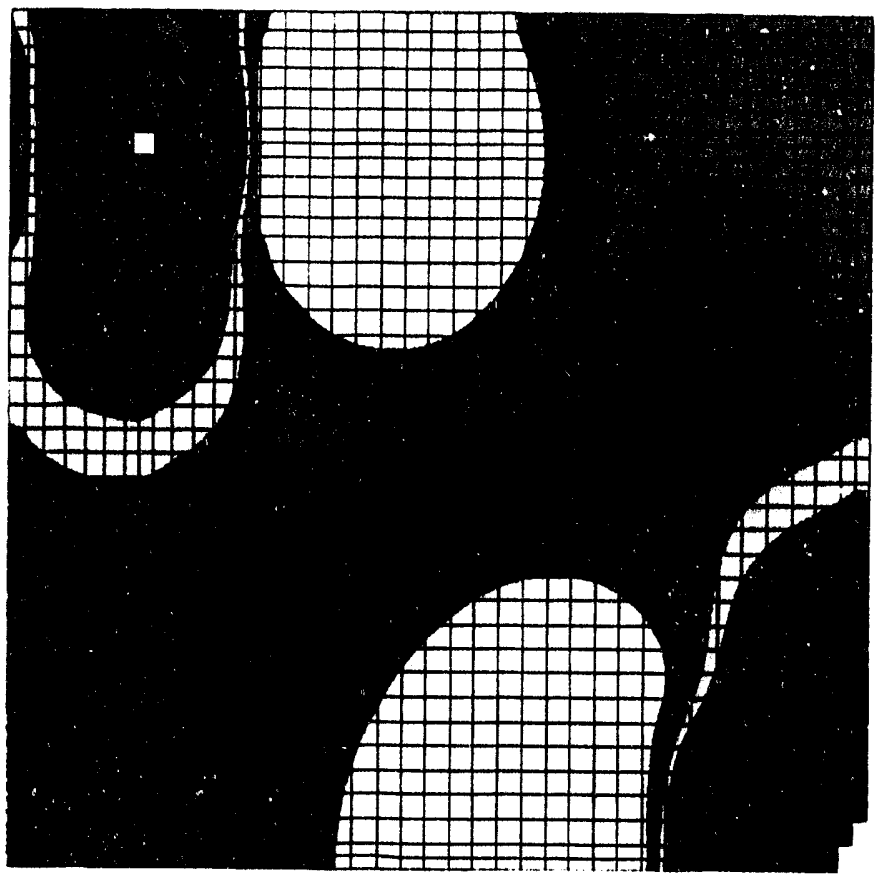

Fringe levels

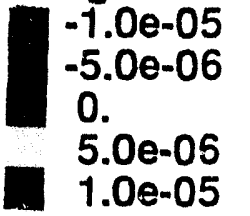

Figure 6-6: Calculated equilibrium vertical-strain on back of plate, caused by 325 Mpa tension in bolts.
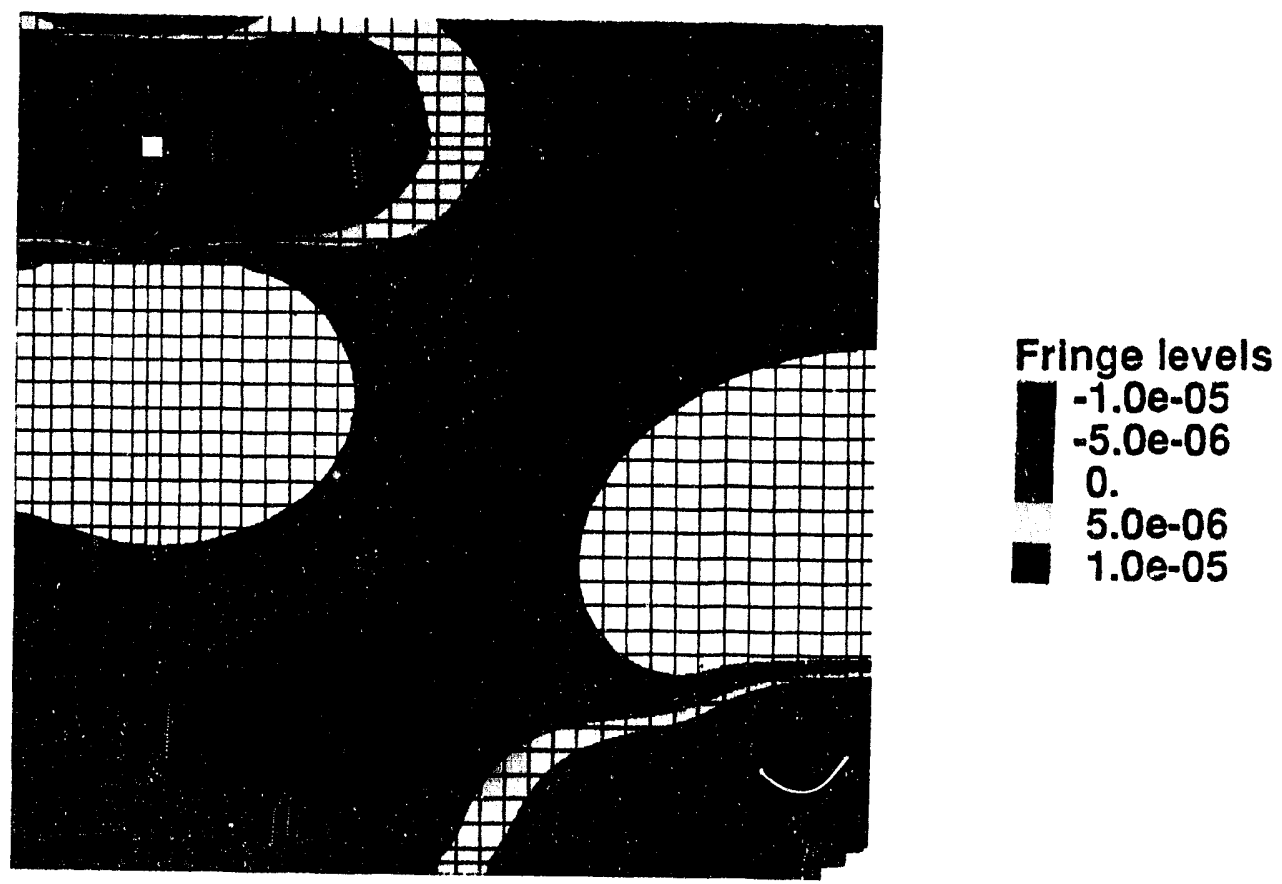

Figure 6-7: Calculated equilibrium horizontal-strain on back of plate, caused by $325 \mathrm{Mpa}$ tension in bolts. 


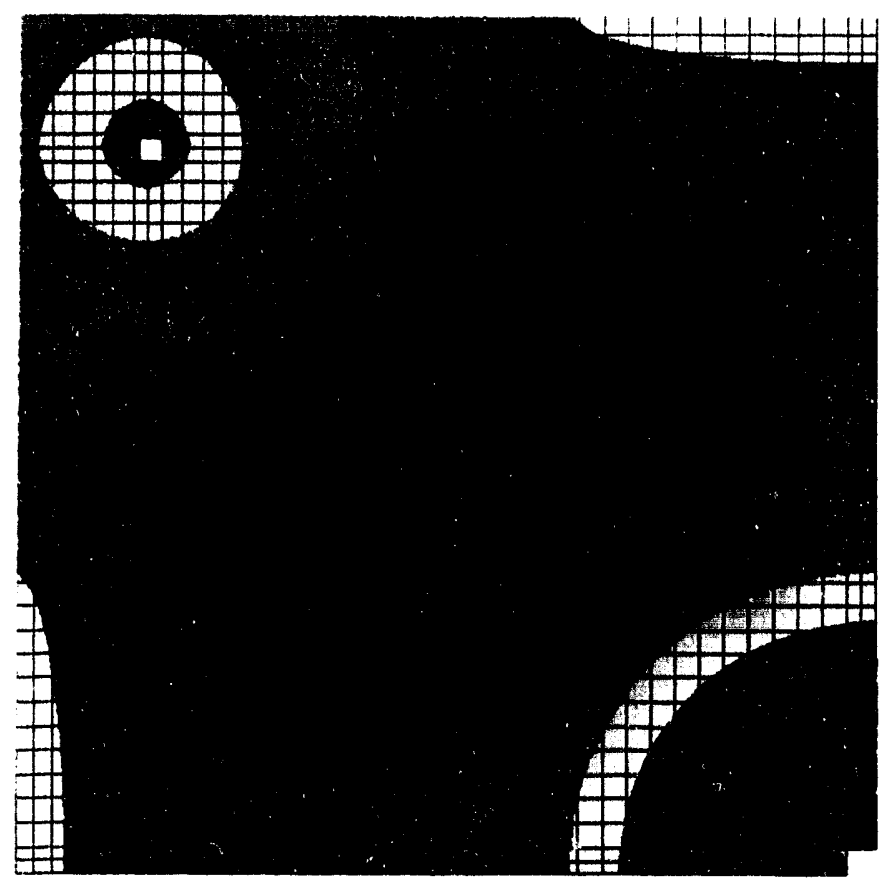

Fringe levels

2.0e-05m

$6.5 \mathrm{e}-05 \mathrm{~m}$

$1.1 \mathrm{e}-04 \mathrm{~m}$

$1.5 \mathrm{e}-04 \mathrm{~m}$

$2.0 \mathrm{e}-04 \mathrm{~m}$

Figure 6-8: Calculated equilibrium displacement into cavity wall, on back of plate, caused by $325 \mathrm{MPa}$ tension in bolts.

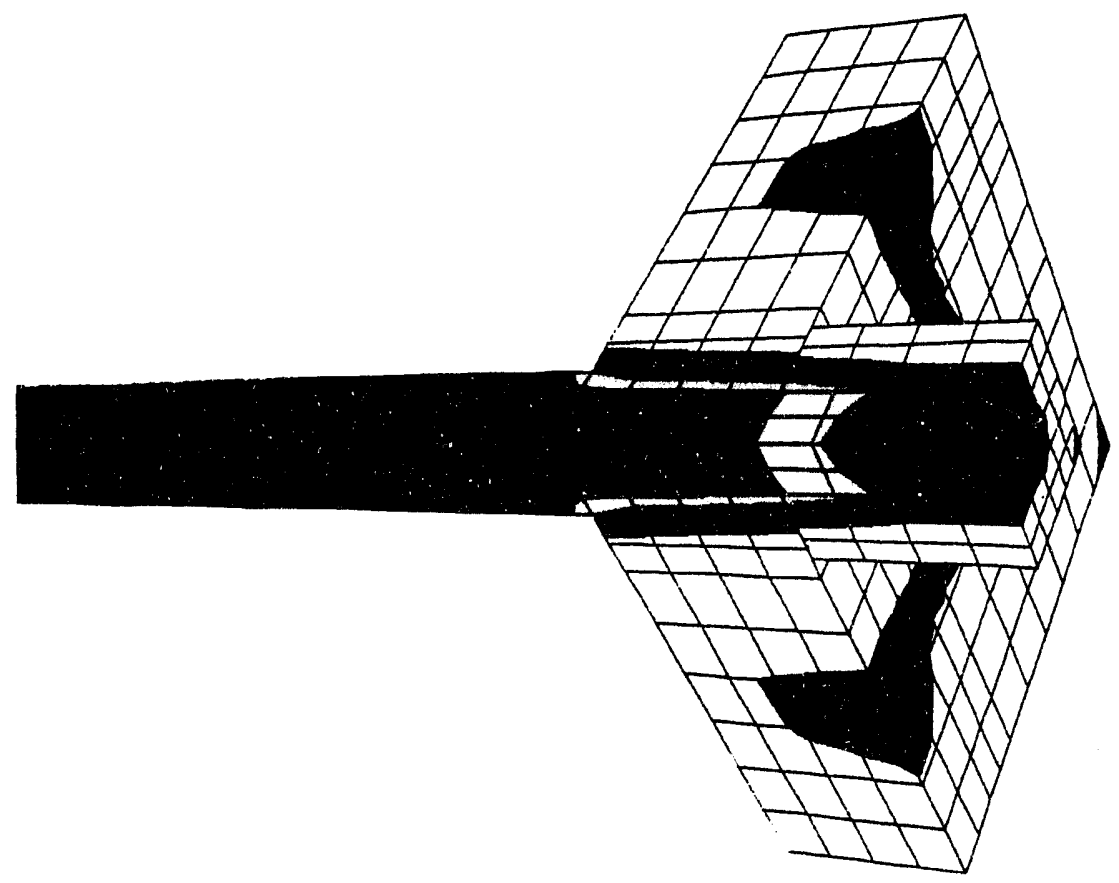

Fringe levels

0.

7.5e+07 Pa

$1.5 e+08 \mathrm{~Pa}$

$2.25 e+08 \mathrm{~Pa}$

$3.0 \mathrm{e}+08 \mathrm{~Pa}$

Figure 6-9: Axial-stress distribution in centerbolt and plate components, from equilibrium calculation. 
- the stiffness and compaction of the rock globally affect the frequency and amplitude of the system response.

- the type of boundary condition used for the cornerbolt-grout interface has a major effect on the bolt response, but very little influence elsewhere.

\subsubsection{Effect of Rock Mass Stiffness}

A sense of the effects associated with rock properties and cornerbolt interface condition is given by examining the calculated stress response of the system. (Comparisons of calculated strains, stresses, and accelerations with experimental data are deferred until Section 8.) Figures 6-10 to 6-16 highlight the differences between results from a "stiff" rock model that does not account for compaction and those from the more representative "soft" model discussed in Section 6.2. The stiff model treats the rock as a Von Mises elastic/plastic material and was used for preliminary pre-shot response estimates before material property characterizations on the tuff and grout were carried out. Parameters assumed for the stiff model were density of $1600 \mathrm{Kg} / \mathrm{m}^{3}$, Young's modulus of $4.0 \mathrm{GPa}$, Poisson's ratio of 0.33 , and yield stress of $40 \mathrm{MPa}$.

Comparisons of the calculated values are mostly given at locations where data were obtained in the experiment. Curves with the solid line represent the stiff model and curves with the dash line represent the soft model. Figure 6-10 shows differences in the central portion of the centerbolt. The soft model reduces the frequency and oscillation amplitude of the response, increases the peak compressive excursions, and decreases the recovery of pre-tension stress. The effect on the oscillation behavior is a result of lower elastic rock constants, while the influence on peak compressive stress and tensile recovery is due to the irreversible nature of compaction. A similar effect is observed for the cornerbolt response in Figure 6-11, except that the frequency content is nearly the same for both models. Note that, in these comparisons the cornerbolt-grout interface in the borehole was treated as unconstrained, i.e., frictionless. Figures 6-12 and 6-13 compare the axial stress in the rock just behind the liner plate and near the midpoint of the pillar. Again, lower frequency and reduced oscillation amplitude are evident with the soft model. Quite significant are the attenuation of the peak stress and an increase of the main pulse width in the pillar associated with the increased dissipation from compaction in the soft model. The influence of 


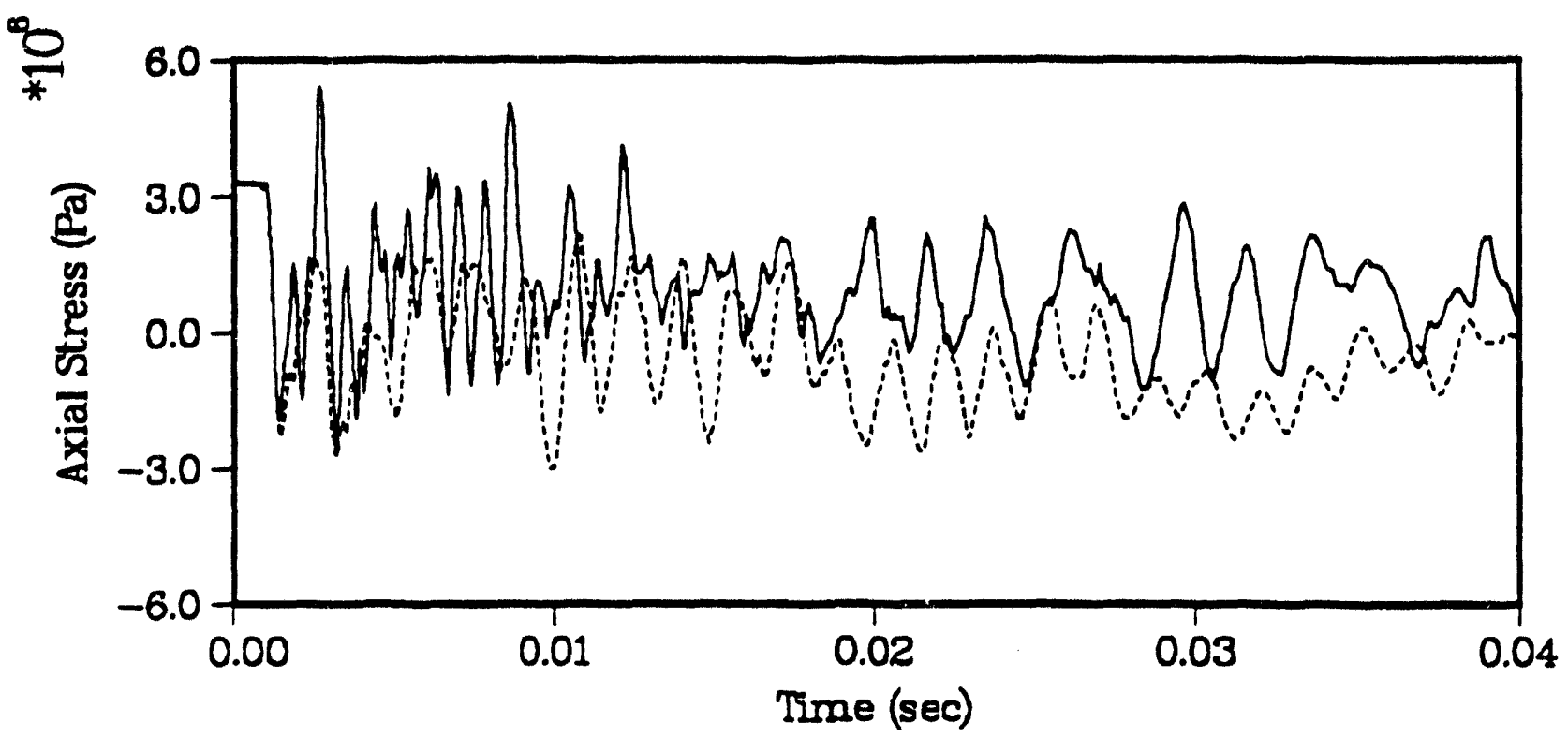

Figure 6-10: Calculated axial stress response in centerbolt (stiff model, solid curve; soft model, dash curve).

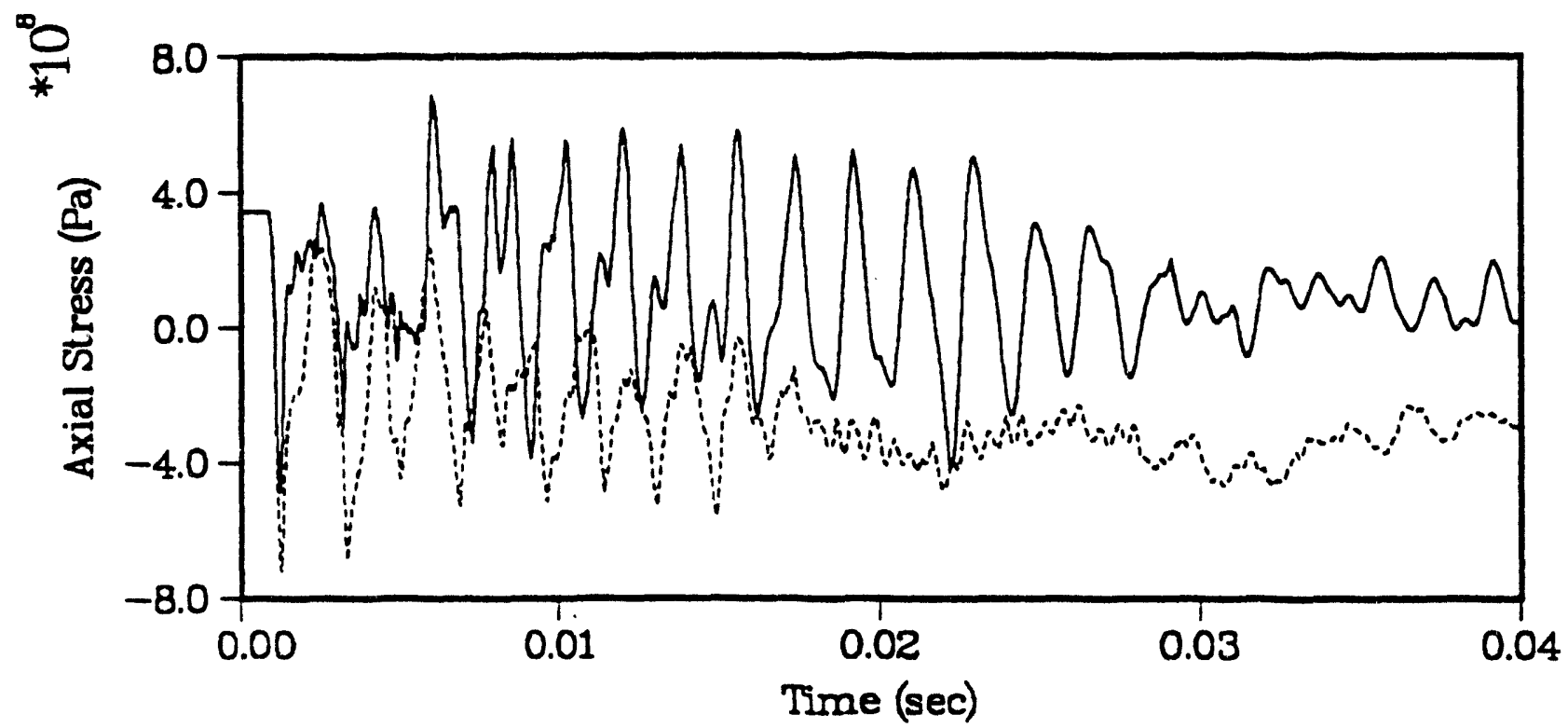

Figure 6-11: Calculated axial stress response in cornerbolt (stiff model, solid curve; soft model, dash curve). 


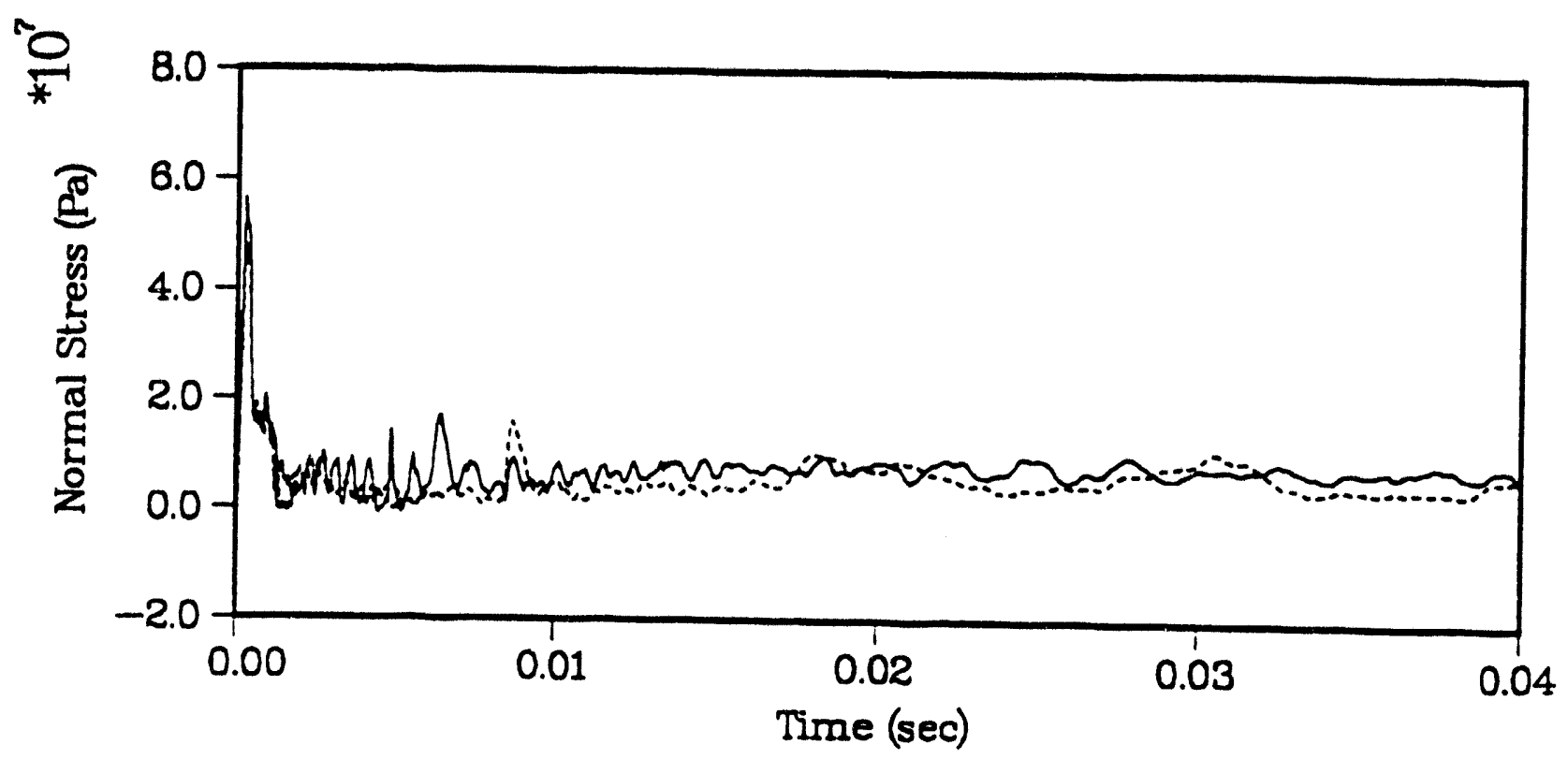

Figure 6-12: Calculated axial stress response in rock behind the plate (stiff model, solid curve; soft model, dash curve).

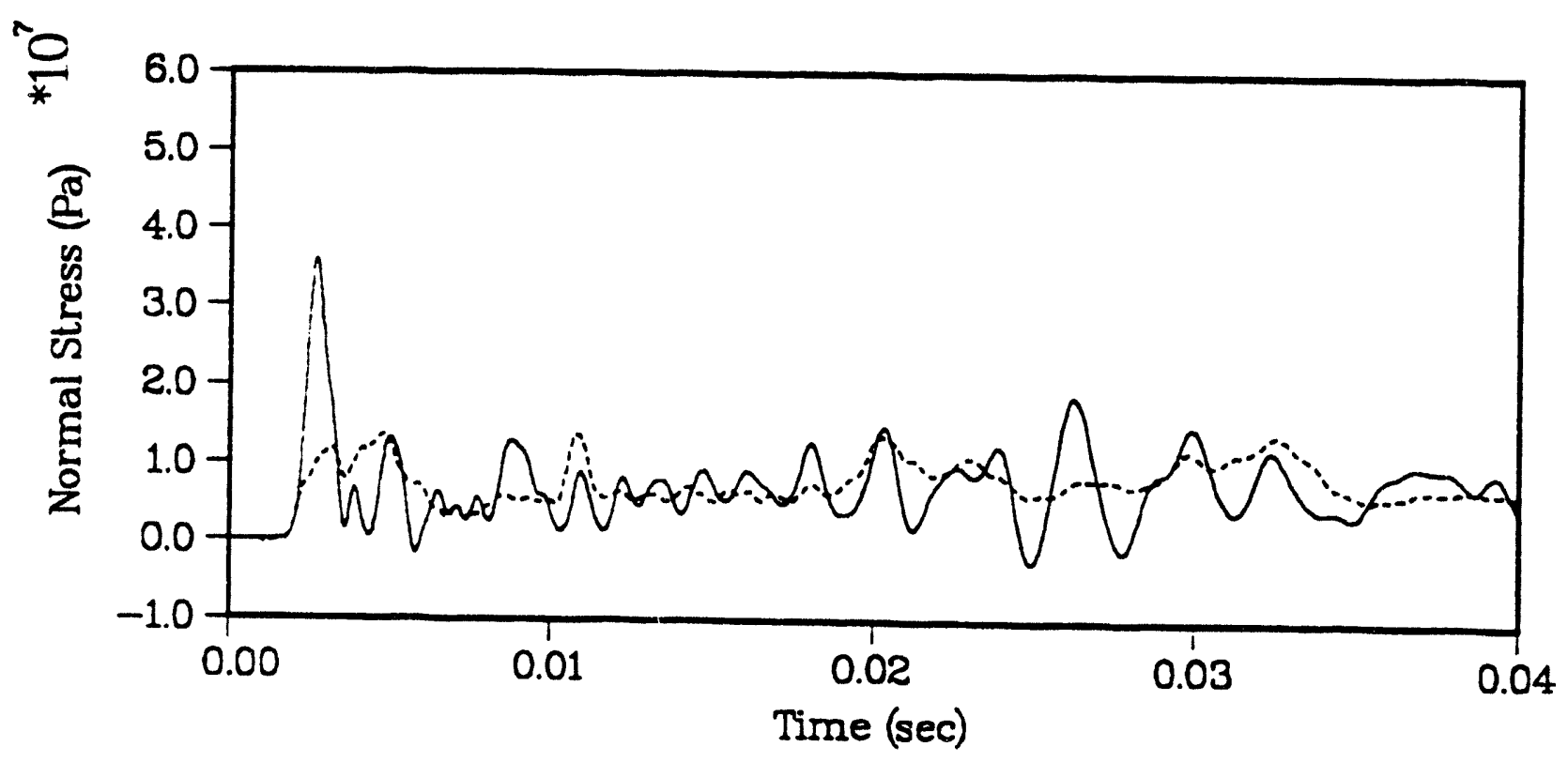

Figure 6-13: Calculated axial stress response midway in the rock pillar (stiff model, solid curve; soft model, dash curve). 
reduced stiffness and compaction on the acceleration in the mid-pillar region is shown in Figure 6-14. The peak associated with the soft model is an order of magnitude lower than that for the stiff model. For reference, the peak acceleration in the liner is of the order of $30,000 \mathrm{~g}$ 's.

Calculated horizontal stress histories in the rear and front of the liner plate, at mid-height half way out to the liner edge, are given in Figure 6-15 for the stiff model and in Figure 6-16 for the soft model. ' high frequency content and very little residual stress at late time are observed for the stiff model. The soft model results in reduced oscillations and significant tensile stress in the rear and compressive stress in front portions of the liner, that reach a nearly constant level from about $5 \mathrm{~ms}$ on. These stresses arise from the increased deformation of the plate occurring in the soft rock model simulations, and their levels are sensitive to the amount of compaction of the rock in the cavity region.

\subsubsection{Effect of Corner Bolt/Grout Interface Properties}

The boundary condition for the cornerbolt-grout interface plays an important role in the calculated response of the cornerbolt. The effect of treating the boltgrout slide-surface as frictionless gives a response similar to that of the unconstrained centerbolt as shown in Figure 6-11. When this interface has some constraint, the response is quite different. This is shown in Figure 6-17 for the soft model, where the response with a frictionless interface is compared to that for a constrained surface having a coefficient of friction of 1.9. Constraining causes the load that the bolt carries and the pulse oscillations to be significantly reduced for the early part of the response. The bolt coupled directly to the rock has a response that reflects the character of a stress wave propagating in rock rather than that of a pulse propagating down a bar with free lateral surfaces. The late time responses for both conditions are very similar, except for some slight vibrations in the response for the unconstrained case. This result combined with the behaviors shown above for the soft and stiff models indicates that the latetime global response of the system is strongly dependent on the energy dissipation character of the rock mass. Note that, treating the bolt-grout interface as totally bonded provided a response similar to that with partial friction, but failed to produce a precursor. 


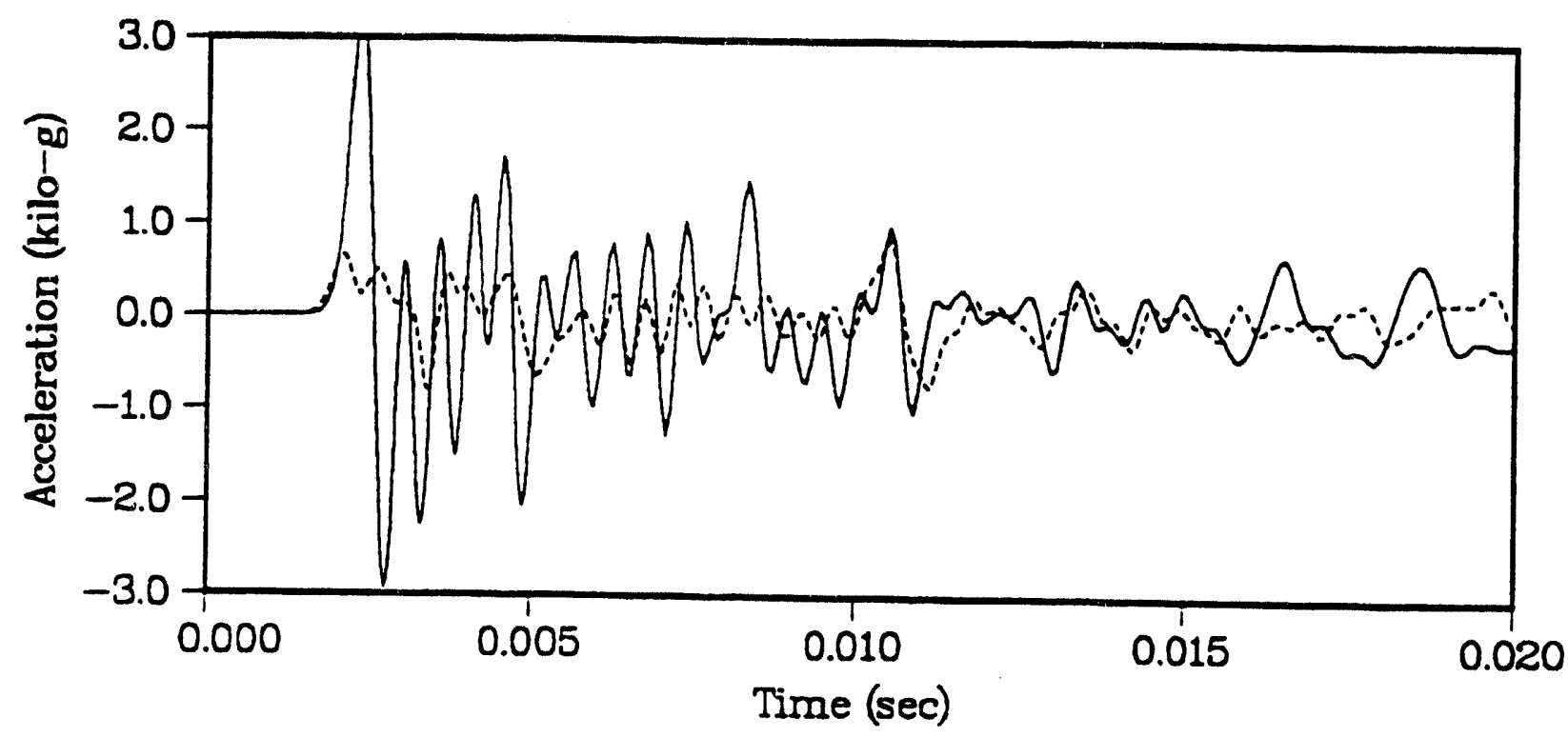

Figure 6-14: Calculated axial acceleration at mid-pillar in rock (stiff model, solid curve; soft model, dash curve).

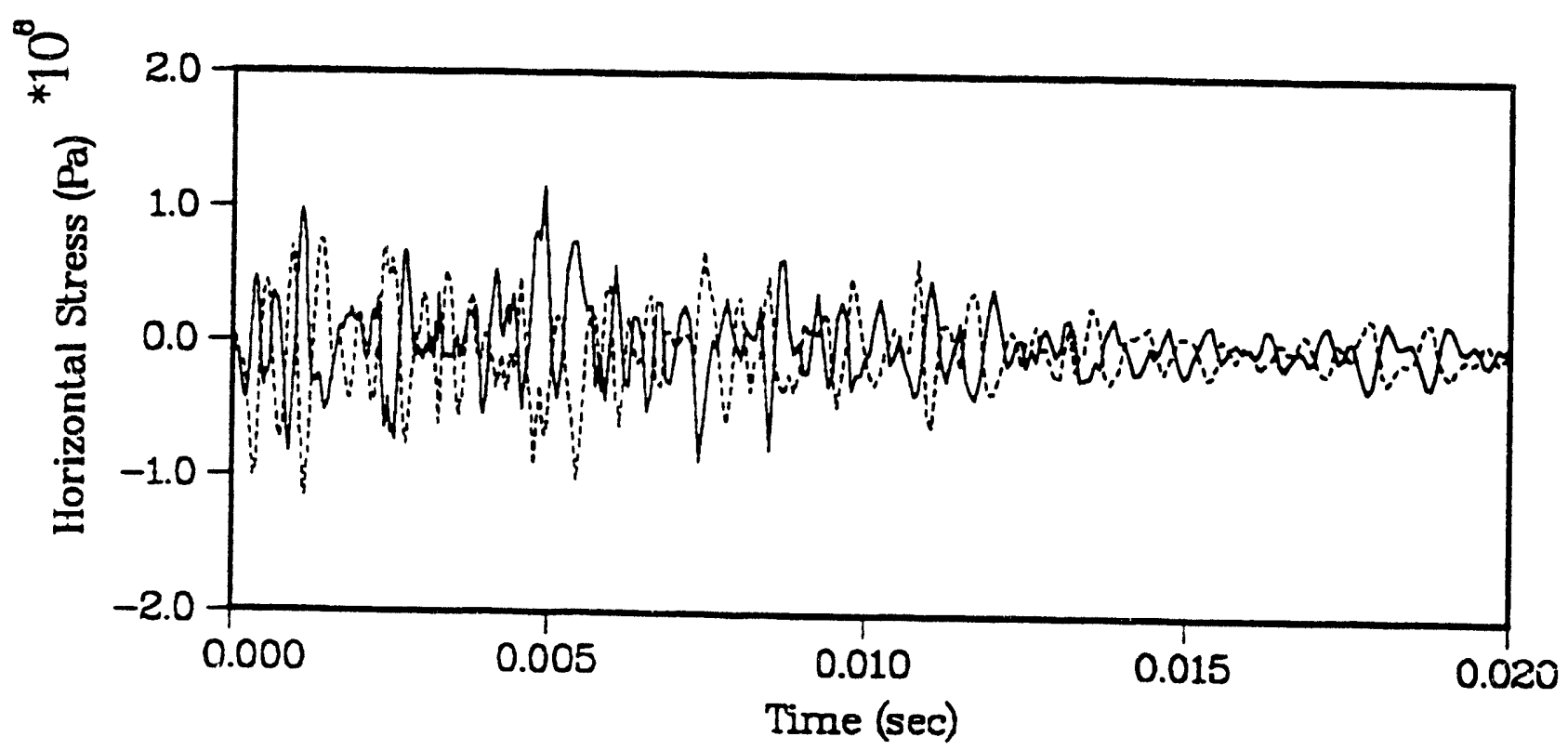

Figure 6-15: Calculated horizontal plate stress at mid-height, half way to edge, stiff model (rear surface, solid curve; front surface, dash curve). 


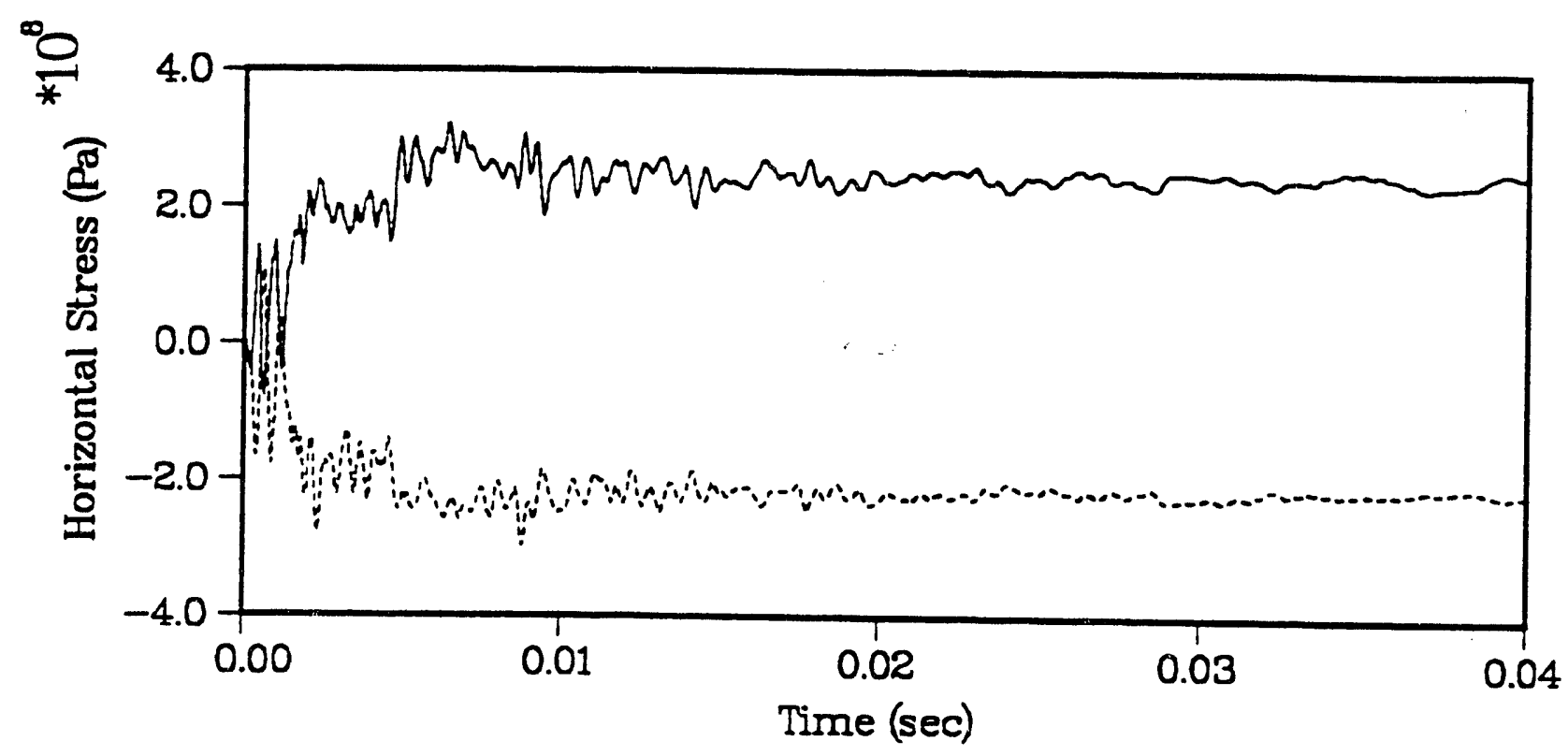

Figure 6-16: Calculated horizontal stress at mid-height half way to edge in plate for soft model (rear surface, solid curve; front surface, dash curve).

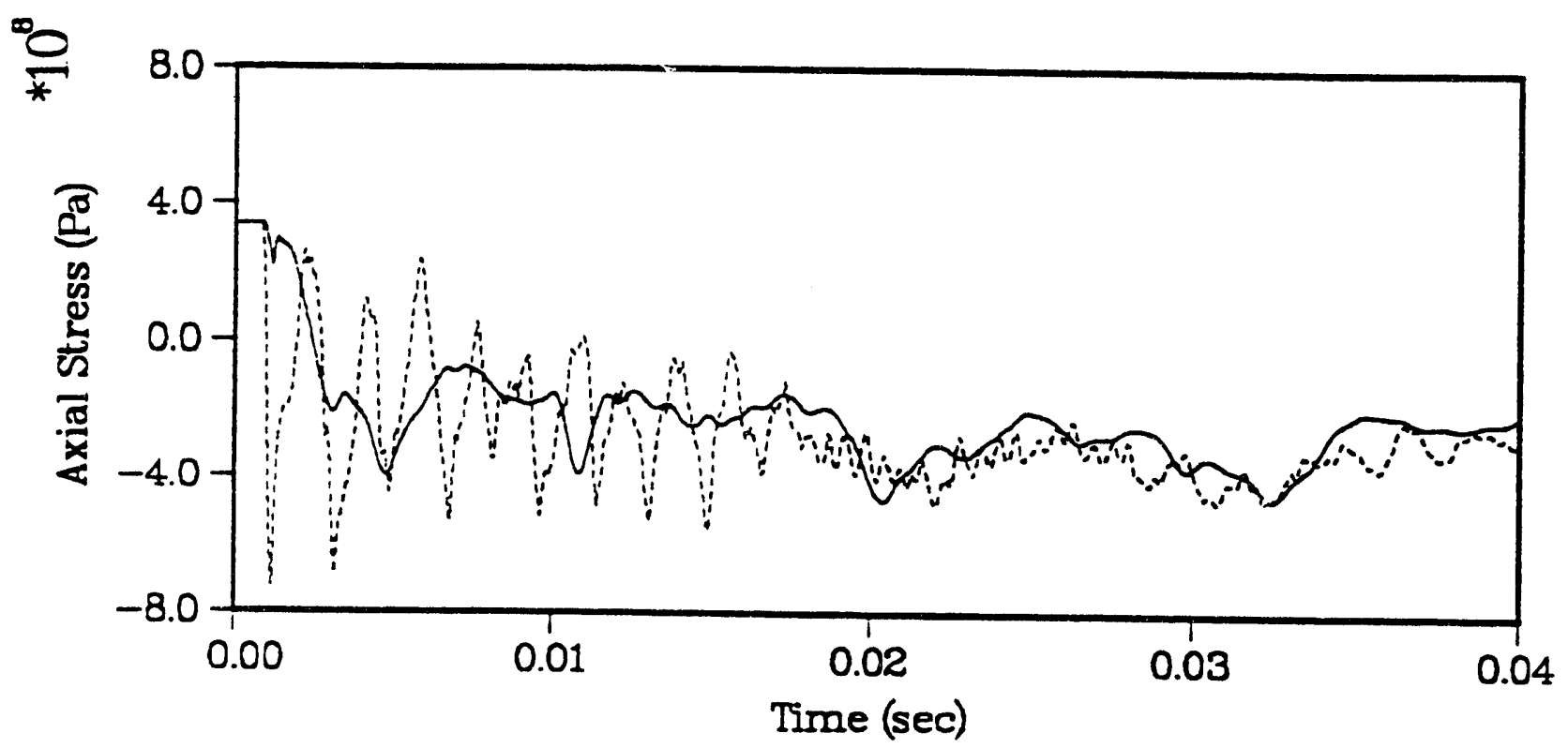

Figure 6-17: Calculated axial stress in cornerbolt comparing effect of bolt-grout interface conditions for soft model. (constrained with friction coefficient 1.9, solid curve; unconstrained, dash curve). 


\section{SECTION 7}

\section{TEST DATA}

\subsection{PRE-TEST MEASUREMENTS}

DIAMOND FORTUNE was executed on April 30, 1992. The plate had been mounted to the wall on February 19. By February 26 the FCP's were in talled. The bolts were tensioned on February 27. The connections were cou ${ }^{*}$ SANDUS on March 24. In the next five weeks preceding the test, num $y$ runs were conducted to check on the operation of all gages.

With particular reference to strain gages, the static loads measured on the day before the shot and on the shot day pre-test baseline are shown in Table 7-1.

Table 7-1: D-day, and D-1 static strain gage measurements from SANDUS.

\begin{tabular}{cllccc} 
Exper. & & & \multicolumn{2}{c}{ Readings (microstrain) } \\
No. & Location & Orientation & & $\underline{D}-1$ & $\underline{\text { D-Day }}$ \\
7100 & Plate, right side & Vertical & & 1235 & 1260 \\
7105 & Plate, right side & Horizontal & 600 & 600 \\
& & & & \\
7110 & Plate, left side & Vertical & -290 & -290 \\
7115 & Plate, left side & Horizontal & -365 & -370 \\
& & & & \\
7200 & Corner bolt, $0.517 \mathrm{~m}^{*}$ & Longitudinal & 5880 & 5840 \\
7205 & Corner bolt, $4.35 \mathrm{~m}^{*}$ & Longitudinal & 2740 & 2730 \\
7210 & Center bolt, $5.016 \mathrm{~m}^{*}$ & Longitudinal & 1990 & 1990 \\
7215 & Center bolt, $5.016 \mathrm{~m}^{*}$ & Longitudinal & 2000 & 2000 \\
7250 & Center bolt, $5.321 \mathrm{~m}^{*}$ & Longitudinal & 2740 & 2730 \\
7255 & Center boit, $5.321 \mathrm{~m}^{*}$ & Longitudinal & 2630 & 2660
\end{tabular}

*From the WP end of the bolt

For convenience these locations are sketched out in Figure 7-1.

The readings on the plate did vary somewhat during the dry runs over the period of March 27 through April 29, before stabilizing. Gage 7100 started at 1180 $\mu$ strain and increased to 1235 . Gage 7105 started at 750 and decreased to 600 . Gage 7110 started at -450 and decreased to -290 . Gage 7115 started at -500 , jumped to 


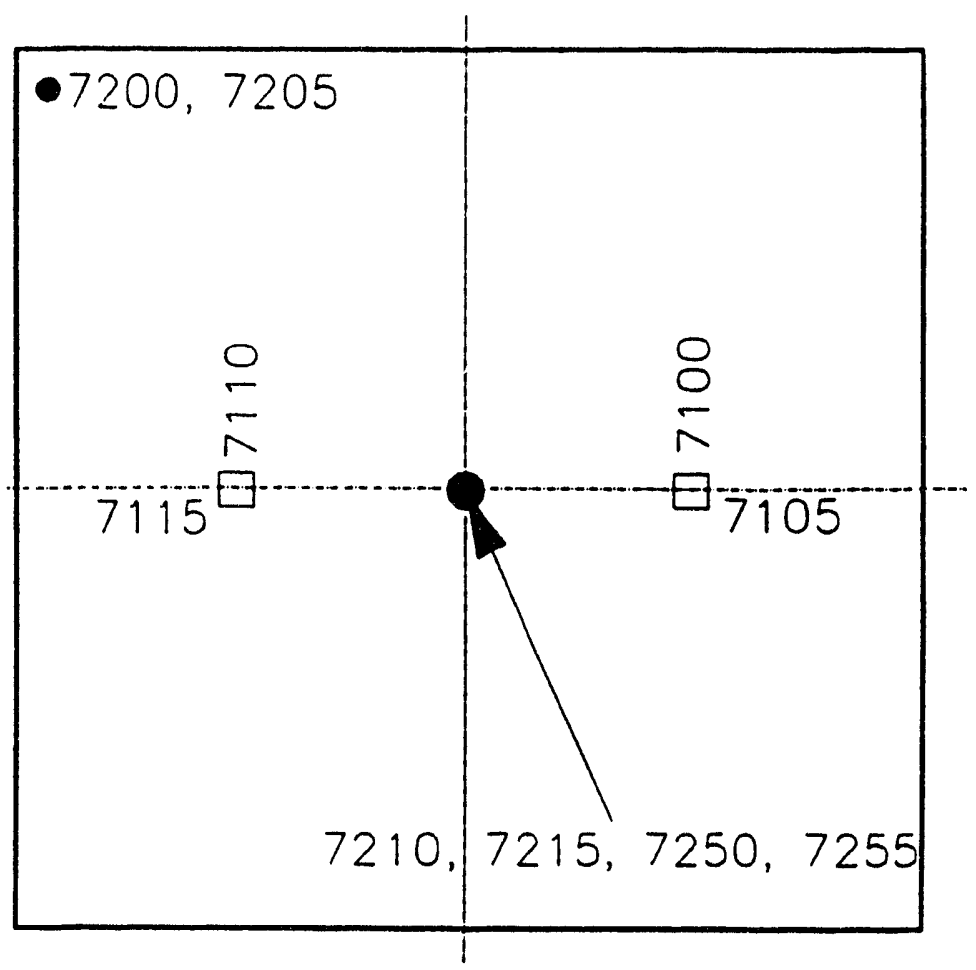

Figure 7-1: Sketch of strain gage location and nomenclature.

-320 on March 31, and then increased steadily to -365 . The reason for the relatively large reading for 7100 is unknown. These were no indications of any problem with the gage at any time during the monitoring period.

The baseline readings on the plate strain gage are puzzling on two more counts:

- first, the right-hand set shows positive values, while the left hand set shows negative values.

- second, the sign of these values does not correspond to the results of NIKE 3D calculations presented in Section 6. Specifically, we would expect tension $(>0)$ for 7105 and 7115 , and compression $(<0)$ for 7100 and 7110 . So, out of the four gages only 7105 and 7110 show the expected sign for strains.

The questions raised concerning the base line values do not necessarily invalidate the dynamic data, but they make it difficult to reliably estimate the absolute strains experienced by the plate during the experiment. On the other hand, if the plate gages functioned satisfactory during the dynamic phase, and did not yield, this would be a strong indication that the plate itself did not yield. 
The static strain readings on the bolts were essentially constant over the monitoring period except for 7200 on the corner bolt. It stayed between 5800 and $6000 \mu$ strain from March 31 to April 16. It varied between 6700 and 6200 until April 29 when it returned to $5880 \mu$ strain. The reading was much too high, indicating a load nearly three times the applied load. We suspect that the gage was beginning to yield. The two sets of $180^{\circ}$ opposed gages $30.1 \mathrm{~cm}$ apart on the center bolt gave self consistent readings. The puzzling aspect is that the two sets were different by about $700 \mu$ strain. One would expect the strain to be constant from one end of the bolt to the other. We have found nothing so far in the gages, cables, or recording system that would account for this difference.

By D-Day, 16 of the 20 SANDUS channels were deemed reliable. Four were not: the side FCP, the center bolt load cell, the corner bolt load washer (drift side) and the corner bolt strain gage closest to the working point (7200). The failure of the first three channels happened after grouting of the run-around drift and is attributed to a combination of moisture and temperature effects. Note also that the top FCP failed after $1.8 \mathrm{~ms}$ in the test, before peak pressure could be obtained.

In addition to the SANDUS channels mentioned so far, 3 load washers on the drift side of the 3 corner bolts that were not strain gaged were wired for handreading. The pig tails were each put in a PVC pipe to be grouted in the tunnel and read post-test, if re-entry could be performed. The hand readings for tension loads in these three corner bolts are shown in Table 7-2

Table 7-2: Tension loads (lbs.) in 3 corner bolt load washers, drift side, read by hand (orientation: facing plate in cavity)

\begin{tabular}{l|lllll} 
Corner & \multicolumn{5}{c}{ Date (1992) } \\
Bolt & $2 / 27$ & $3 / 2$ & $3 / 3$ & $3 / 9^{*}$ & $4 / 16^{* *}$ \\
\hline $\begin{array}{c}\text { Upper right } \\
(7054)\end{array}$ & 37,070 & 35,740 & 35,730 & 27,700 & 38,250 \\
$\begin{array}{c}\text { Lower right } \\
(7055)\end{array}$ & 36,500 & 35,080 & 35,150 & 29,510 & 39,900 \\
$\begin{array}{c}\text { Lower left } \\
(7057)\end{array}$ & 36,500 & 35,100 & 35,070 & 33,670 & 40,110
\end{tabular}

* bolt grouting: the heat from grout curing created a thermal expansion of the bolts and reduced the tension.

** the bolts recovered to a somewhat higher tension than the initial values; this could be due to curing shrinkage of the grout. 


\subsection{TEST DATA}

The data are summarized in the order of the gauges from Table 4-1.

\subsubsection{Loading on Rock}

The rock pillar accelerometer data to $80 \mathrm{~ms}$ (Figure 7-2) shows a spike reaching about $485 \mathrm{~g}^{\prime}$.

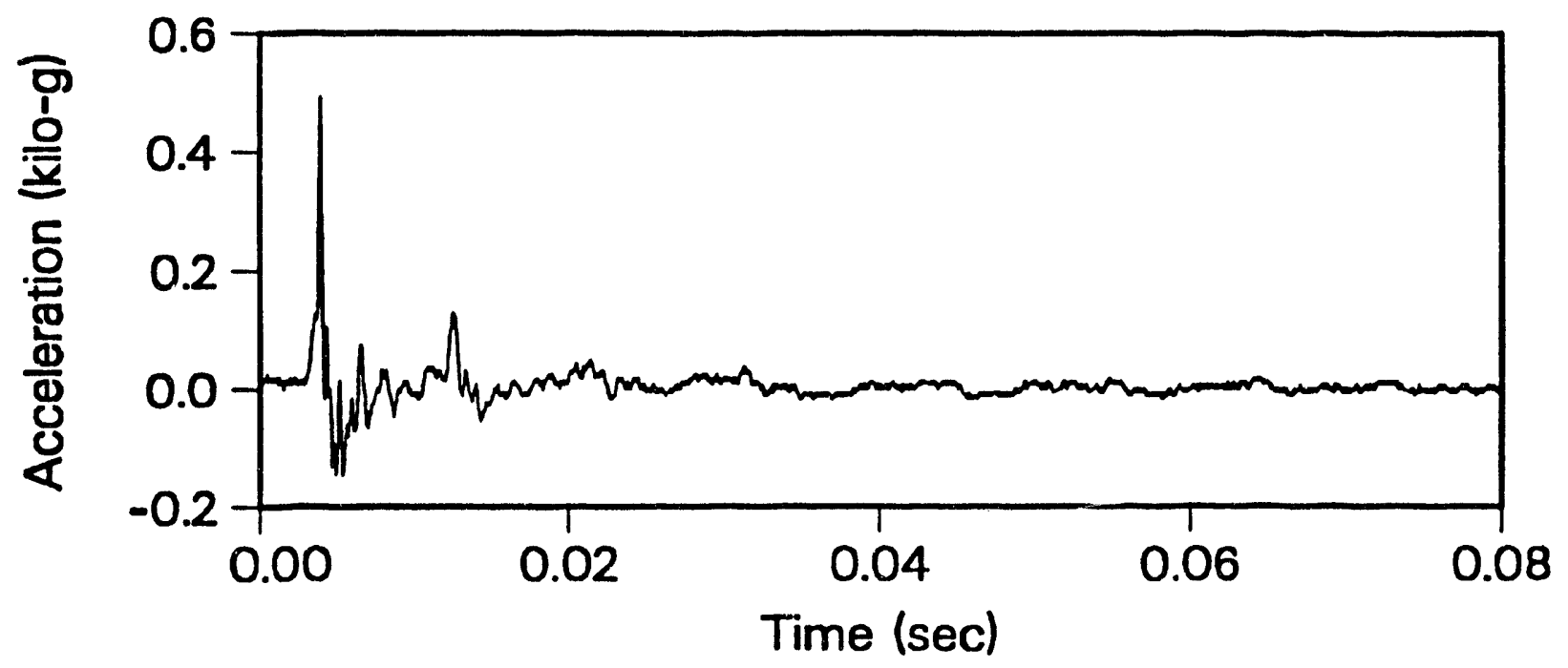

Figure 7-2: Accelerometer record, nearly 4-m into rock pillar.

The floor FCP pressure history is shown in Figures 7-3 and 7-4*. Clearly this information is not sufficient to define the exact blast pressure history on the CONVEX plate. It was known that the cavity flow field is quite complex, based on measurements by Sandia in previous events and on calculations by LANL** and S-CUBED**. This is why the liner add-on design called for three FCP's to be placed a bottom, top and one side of the plate. In the absence of the complete FCP data set, an average pressure history on the front of the plate was inferred from the toadstool data.

\subsubsection{Loading on Plate}

Figure 7-5 shows the accelerometer record on the back of the plate. There is a peak of about $36,000 \mathrm{~g}$ 's $2 \mathrm{~ms}$ after initial impact and another spike to $6,500 \mathrm{~g}$ about $8 \mathrm{~ms}$ later. This second spike is very consistent with the toadstool records.

* Zero time starts when the pressure build-up starts on the wall. TOA is not shown for classification purposes.

** C. Snell (LANL) and E. Peterson (S-CUBED), private communications. 


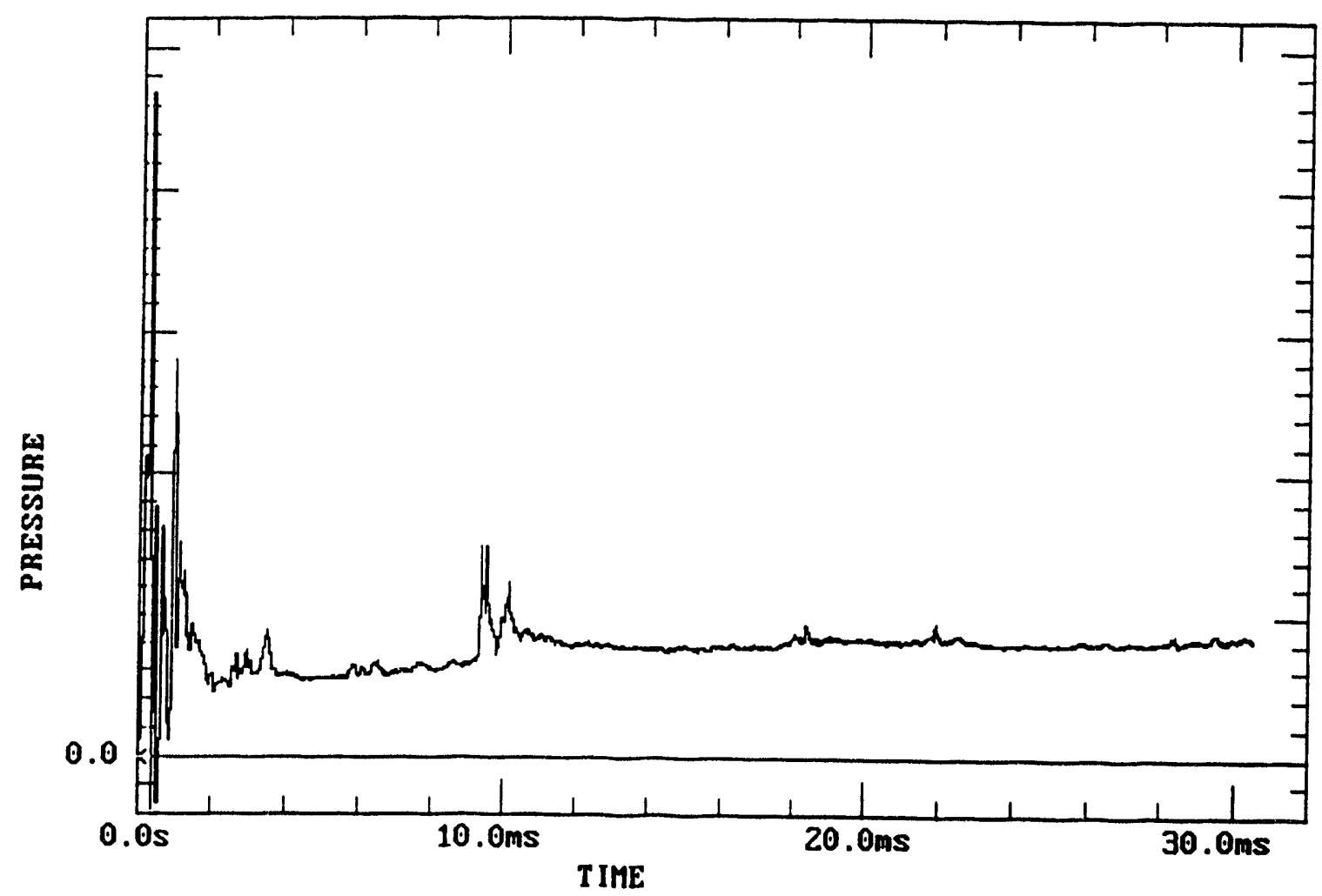

Figure 7-3: Floor FCP (7010) pressure history to 30 milliseconds. No TOA shown.

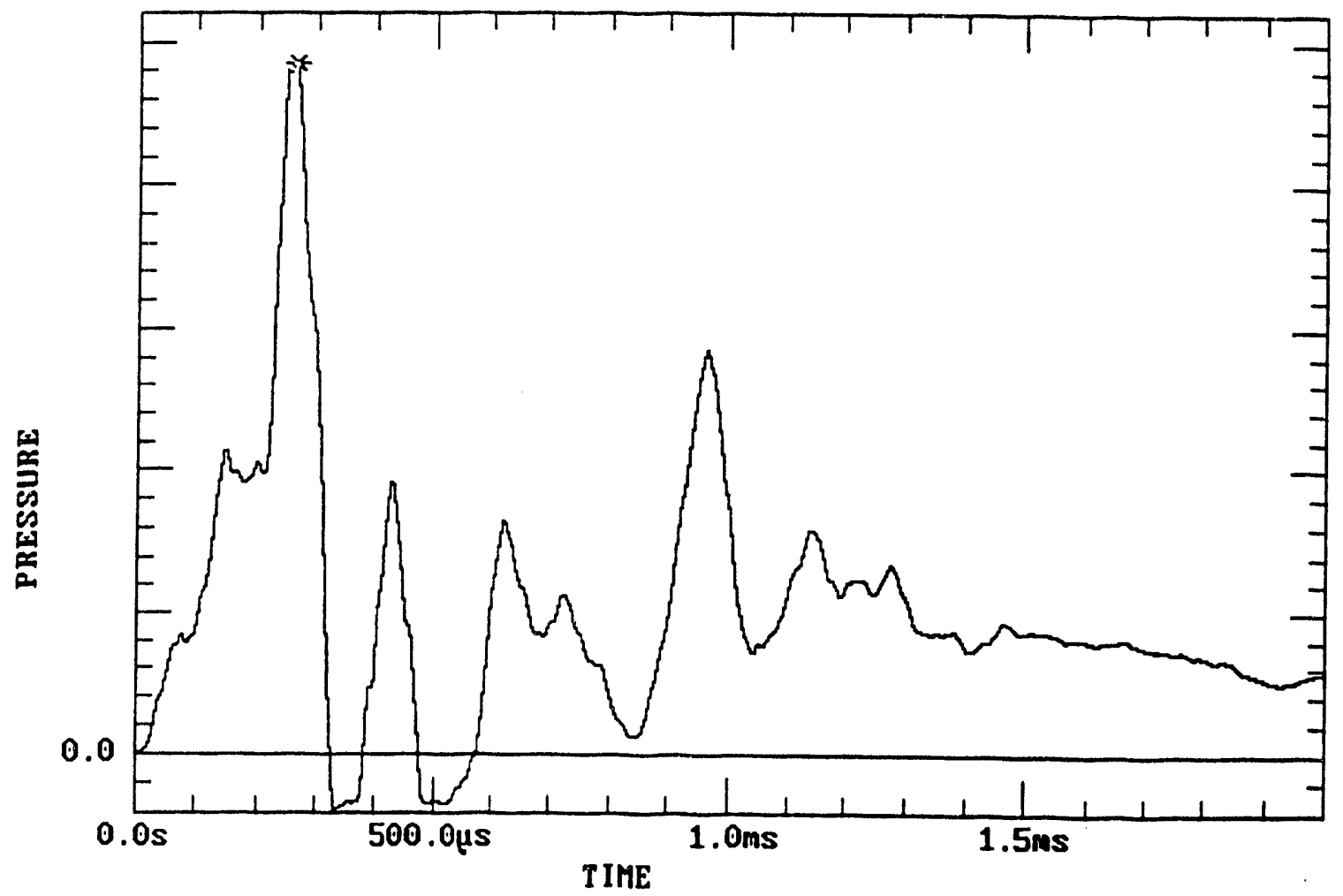

Figure 7-4: FCP 7010 data expanded for the first 2 ms. No TOA shown. 


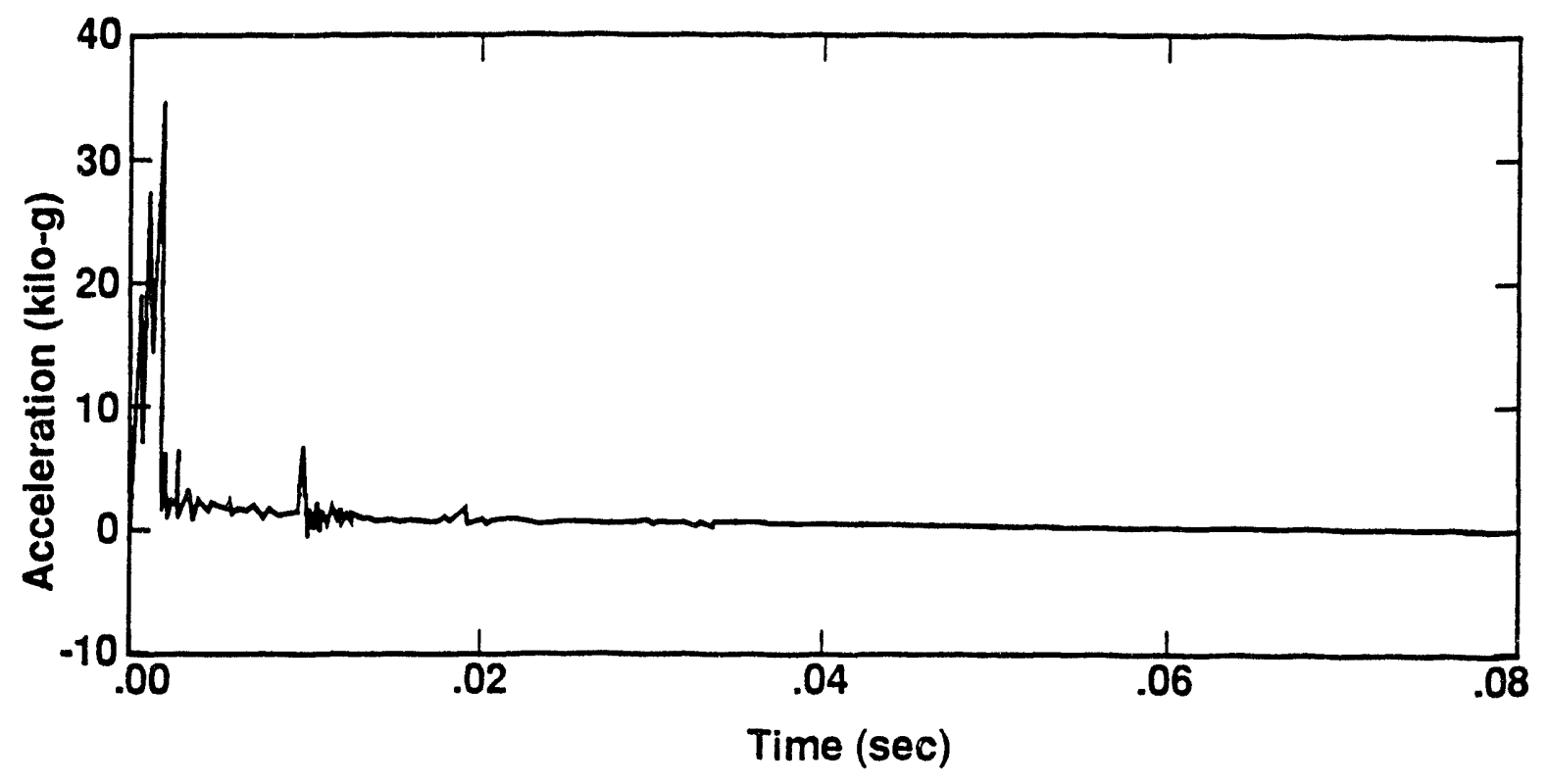

Figure 7-5: Accelerometer record on back side of liner plate. No TOA shown.

The thermocouple record covered a very long period of time compared to all other channels. The discrete time history of temperature is given in Table 7-3.

Table 7-3: Temperature-time history on back of liner plate.

\begin{tabular}{|c|c||c|c||c|c|}
$\begin{array}{c}\text { Time } \\
(\mathrm{s})\end{array}$ & $\begin{array}{c}\text { Temp } \\
\left({ }^{\circ} \mathrm{c}\right)\end{array}$ & $\begin{array}{c}\text { Time } \\
(\mathrm{s})\end{array}$ & $\begin{array}{c}\text { Temp } \\
\left({ }^{\circ} \mathrm{c}\right)\end{array}$ & $\begin{array}{c}\text { Time } \\
(\mathbf{s})\end{array}$ & $\begin{array}{c}\text { Temp } \\
\left({ }^{\circ} \mathrm{c}\right)\end{array}$ \\
\hline 1 & 7.95 & 15 & 181 & 900 & 554 \\
2 & 11.33 & 20 & 217 & 1200 & 530 \\
3 & 12.05 & 30 & 301 & 1500 & 506 \\
4 & 13.25 & 60 & 414 & 3000 & 386 \\
5 & 15.66 & 90 & 470 & 4500 & 310 \\
6 & 20.5 & 180 & 542 & 6000 & 253 \\
7 & 26.5 & 300 & 578 & 7500 & 217 \\
8 & 35.2 & 450 & 590 & 9000 & 188 \\
9 & 45.8 & 600 & 578 & 14,400 & 143 \\
10 & 109.0 & 750 & 574 & &
\end{tabular}

The temperature never was a factor in the dynamics phase records which typically lasted less than $0.2 \mathrm{sec}$. In particular, no thermal corrections were required for the strain gage data.

The plate strain records for the dynamic phase are shown in Figures 7-6 to 7-9 to $40 \mathrm{~ms}$. The $10 \mathrm{~ms}$ spike and the cavity pressure oscillations are clearly seen and are consistent with the records from bolt gages and toadstools. 


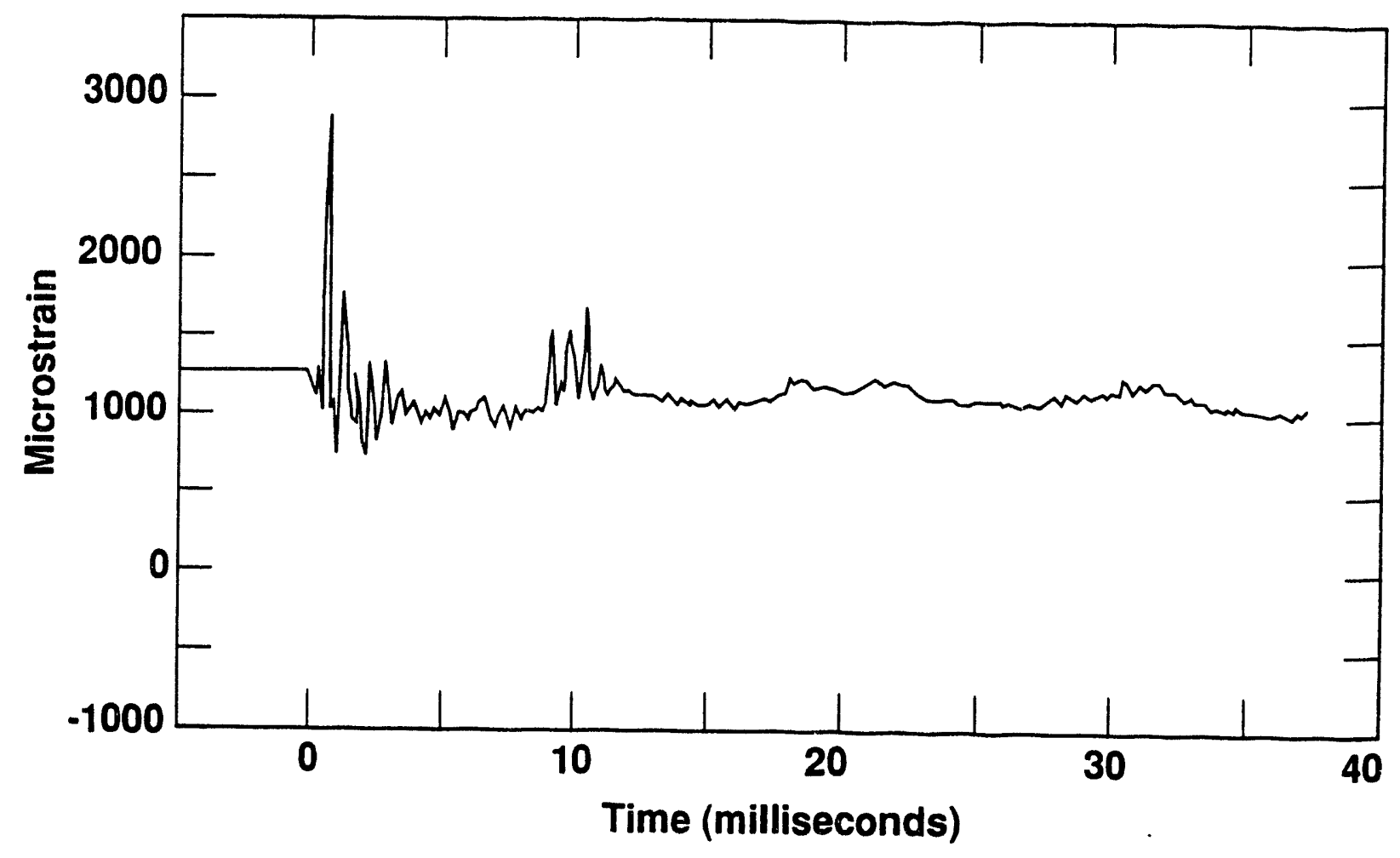

Figure 7-6: Plate vertical strain history, right side (7100). No TOA shown.

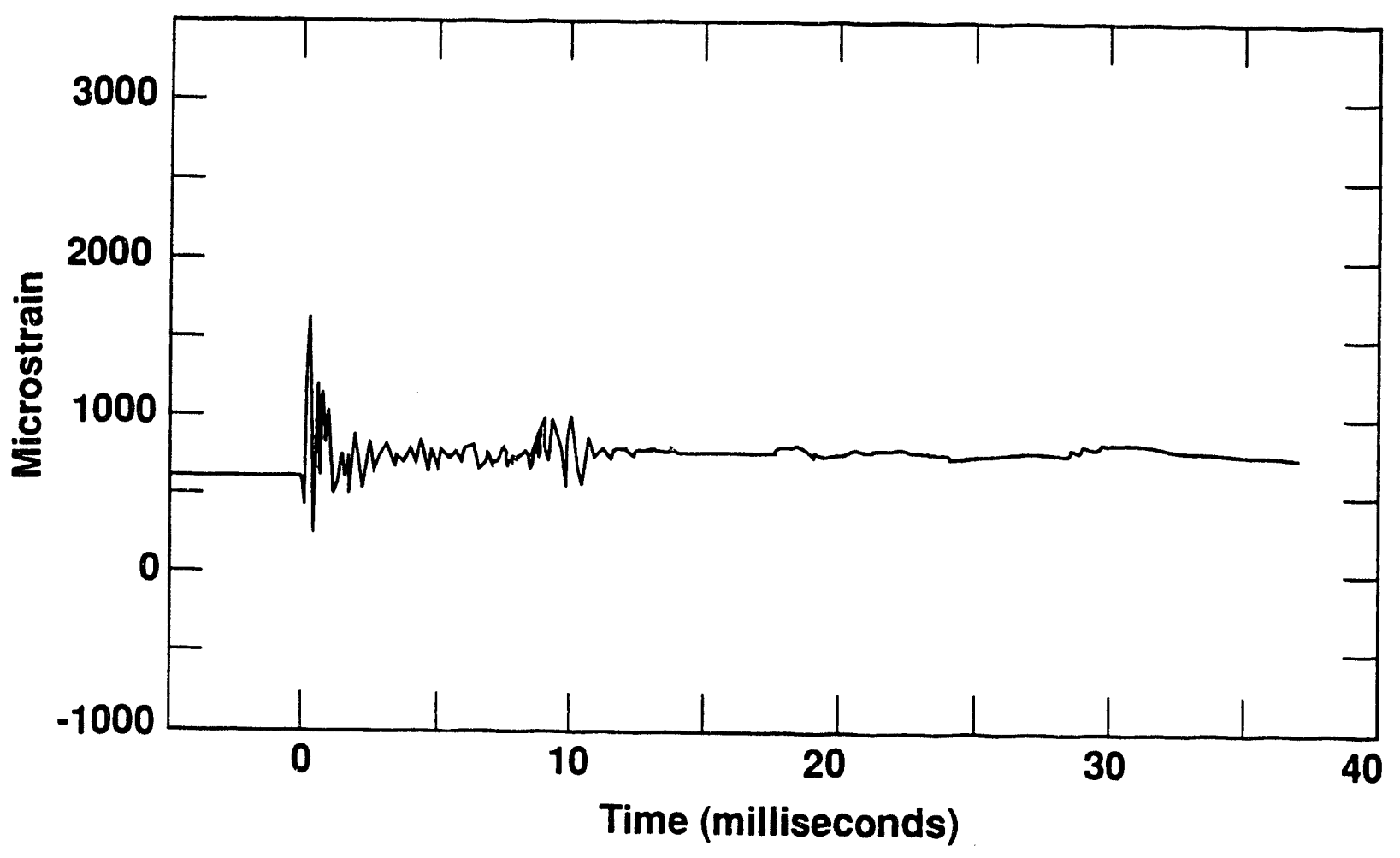

Figure 7-7: Plate horizontal strain history, right side (7105). No TOA shown. 


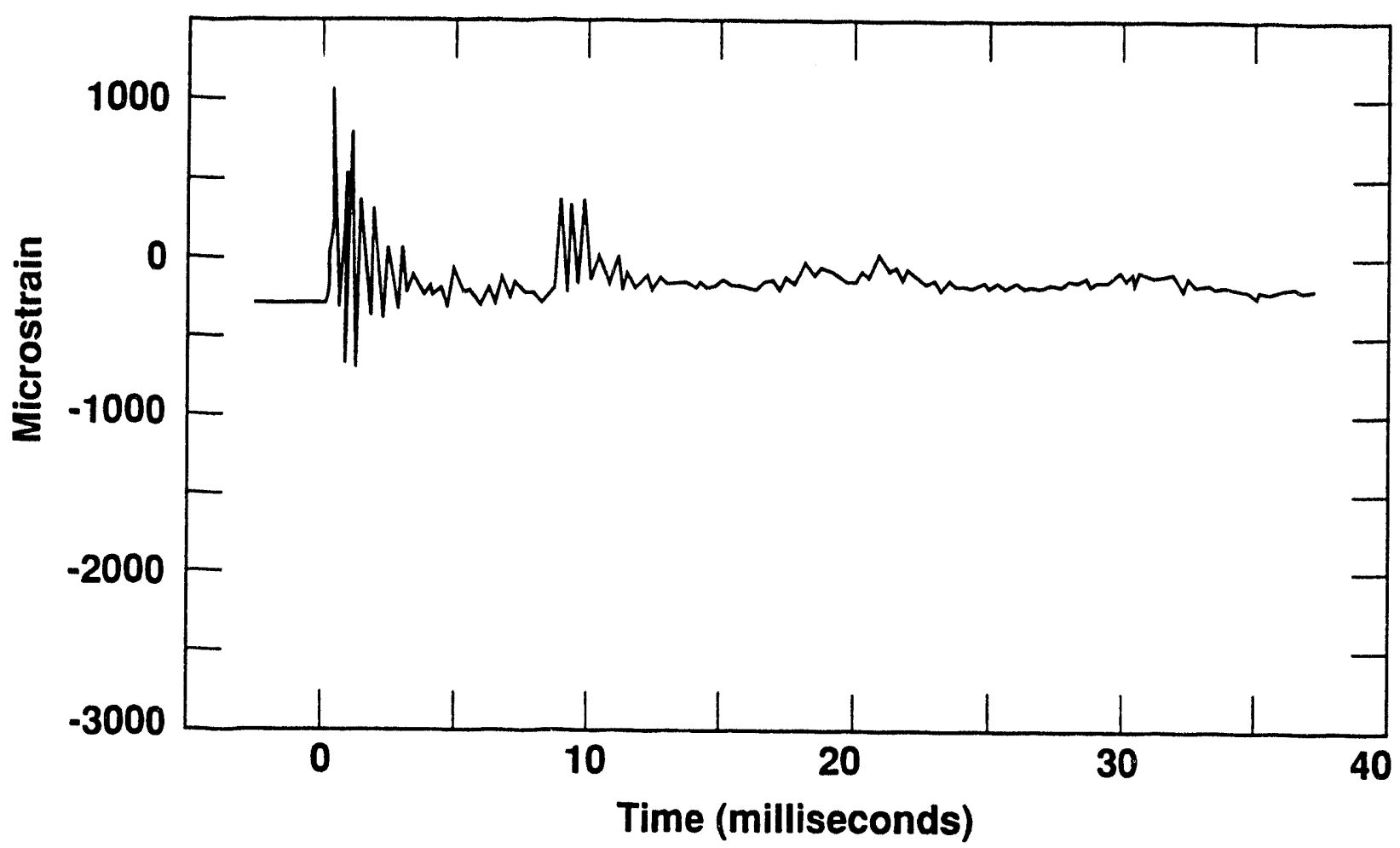

Figure 7-8: Plate vertical strain history, left side (7110). No TOA shown.

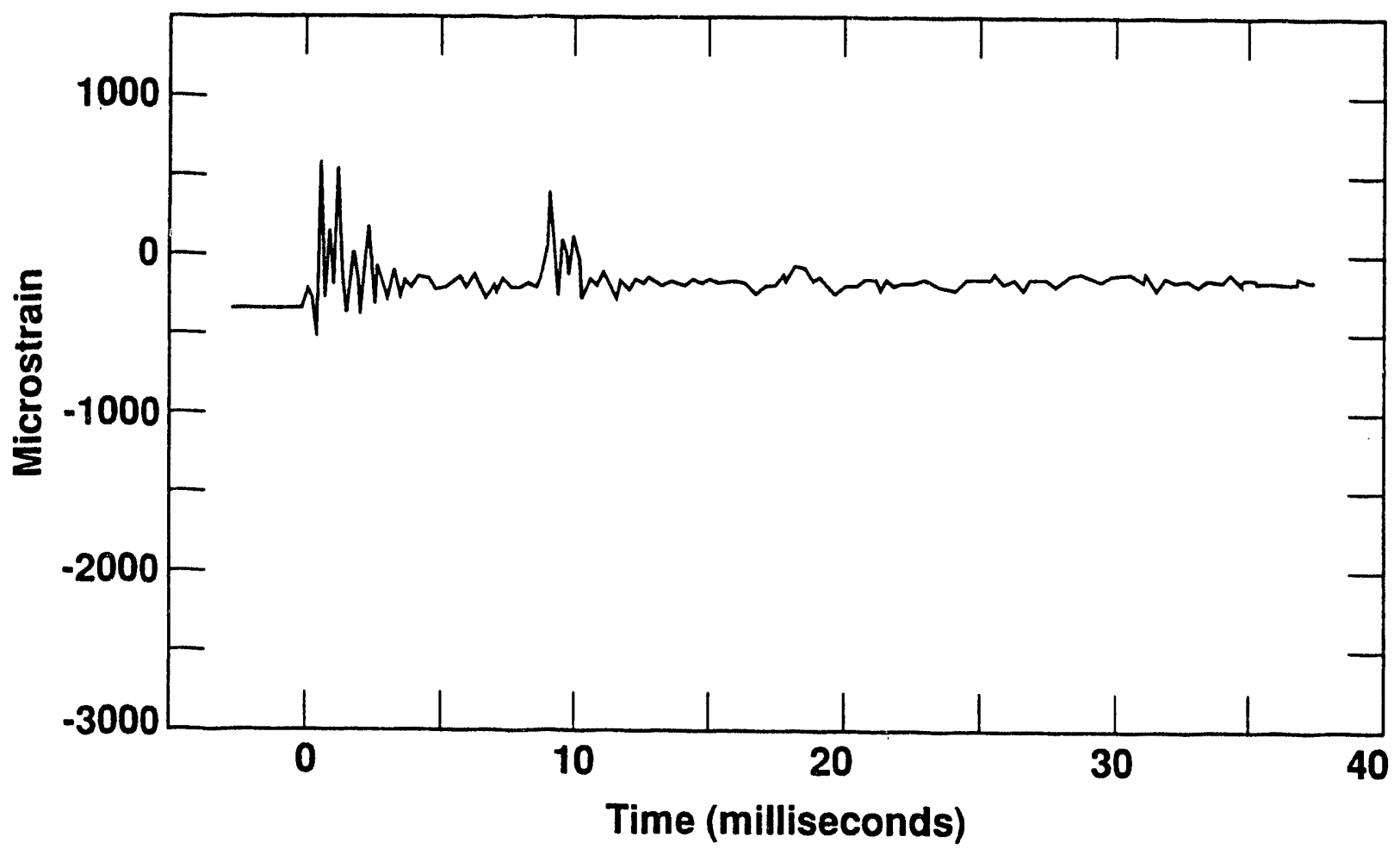

Figure 7-9: Plate horizontal strain history, left side (7115). No TOA shown. 


\subsubsection{Plate-Rock Contact}

As shown in Figure 7-10 both the left (7500) and right (7505) toadstools gave data. There is good agreement between them up to 32-ms, when recording ceased on gage 7500 . The peak dynamic contact pressure was about $70 \mathrm{MPa}$. To put this in perspective, the pre-tension total bolt force divided by the plate area is about 0.6 $\mathrm{MPa}$; this would be the initial contact pressure if the plate were infinitely rigid. Clearly, the dynamic contact pressure was up to two orders of magnitude greater than the initial pretensioning contact pressure. The record of gage 7505 shows a substantial contact pressure remaining between plates and rock. This indicates that the major operational objective of the liner add-on was fulfilled.

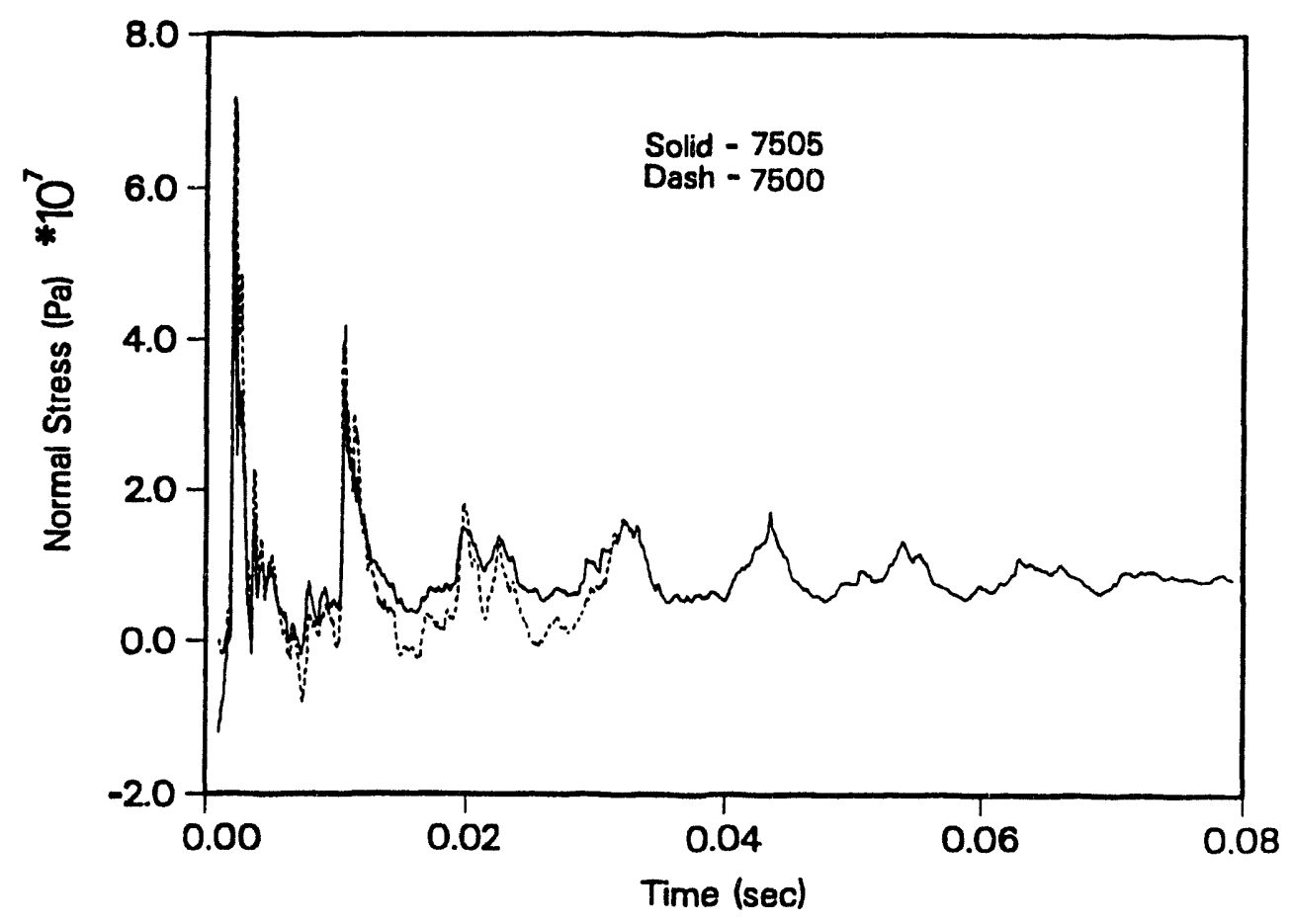

Figure 7-10: Toadstool records behind liner plate. No TOA shown.

\subsubsection{Loading on Bolts}

Even though the center bolts gage pairs had different $D$-day baselines (table 7-1), their dynamic records were strikingly similar. Figure 7-11 shows the four time-histories adjusted for a common starting point, out to 80-ms. Regardless of the absolute value of the initial tension strain, the bolt lost about $1430 \mu$ strains in the first $2-\mathrm{ms}$, and stabilized at $80-\mathrm{ms}$ with a permanent reduction of about 
$417 \mu$ strains. There are three possible starting points for the initial bolt tension at D-day: $324 \mathrm{MPa}$, as on March 3, $400 \mathrm{MPa}$ as from gages $(7210,7215)$, or about 540 $\mathrm{MPa}$ as from gages $(7250,7255)$. Conservatively, we will use the figure of $324 \mathrm{MPa}$. Then, the peak loading at $2 \mathrm{~ms}$ brought the tension down to $48 \mathrm{MPa}$, a reduction of $88 \%$; and the bolt quickly recovered to $241 \mathrm{MPa}$. Thus, conservatively we conclude that the bolt retained at least $74 \%$ of its initial tension, at the end of the dynamic phase. For the other two assumptions the final recovery would be $79 \%$ and $85 \%$ respectively.

The upper left corner bolt record at mid-pillar is shown in Figure 7-12. With the same reasoning as above, the initial tension is either $312 \mathrm{MPa}$, as on March 3, or $547 \mathrm{MPa}$ per gage 7205 . The maximum tension loss at $5 \mathrm{~ms}$ is $1000 \mu$ strains, and the permament reduction is $256 \mu$ strains. Using the $312 \mathrm{MPa}$ figure, the peak loss would be $200 \mathrm{MPa}$, a $64 \%$ reduction; and the stabilized value would be $261 \mathrm{MPa}$, which is $84 \%$ of initial. For an initial tension of $547 \mathrm{MPa}$ and a permanent loss of $51 \mathrm{MPa}$, the final recovery would be $91 \%$.

It is clear that this corner bolt retained somewhat more of its initial tension than the center bolt i.e. at least $84 \%$ versus $74 \%$. This can be reasonably attributed to the bolt being grouted. The grouting also is responsible for the higher damping of load oscillations in Figure 7-12, compared to Figure 7-11.

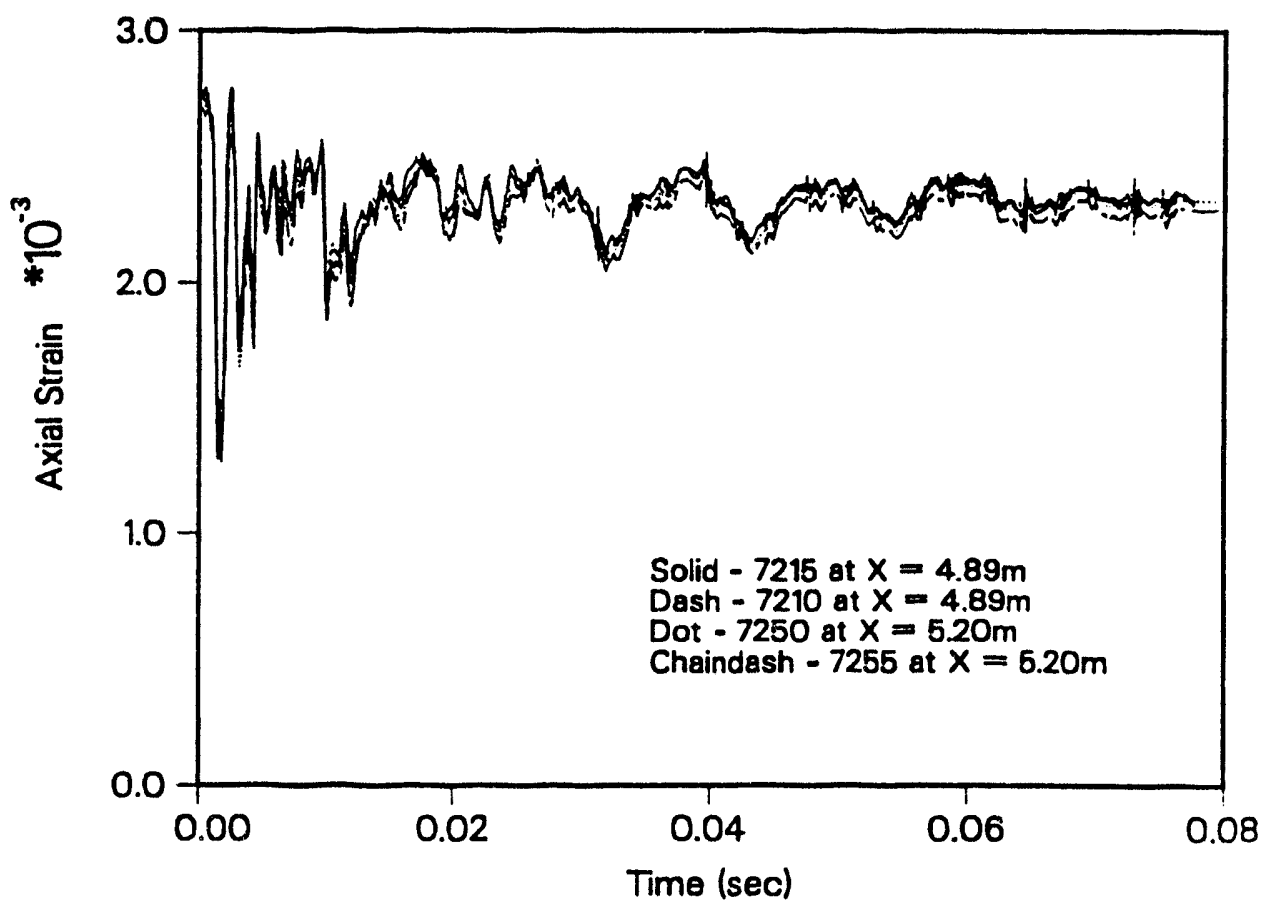

Figure 7-11: Four center bolt strain gage records; note the remarkable consistency. 


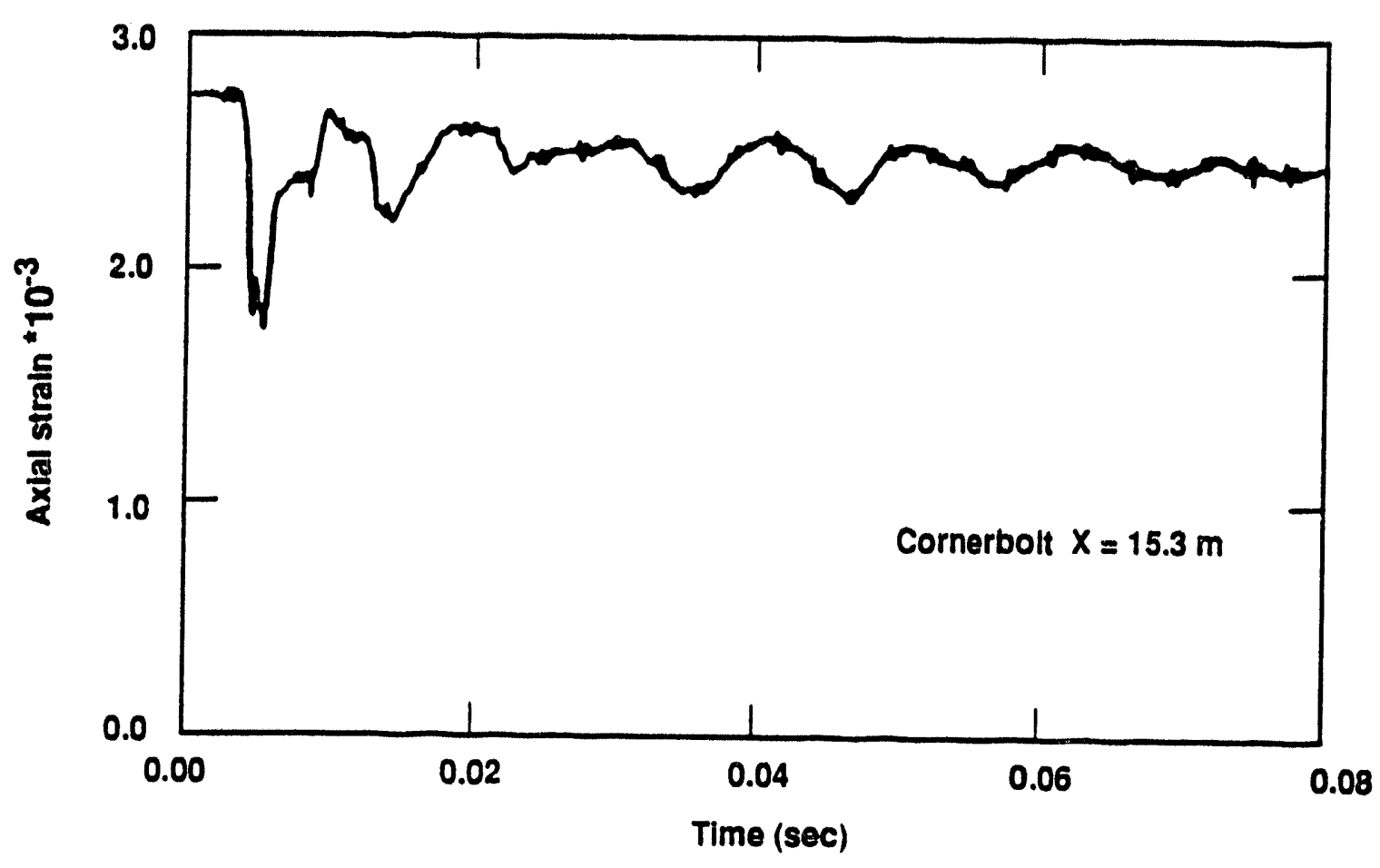

Figure 7-12: Upper left corner bolt strain gage record at mid-pillar.

\subsection{DATA FROM RE-ENTRY}

A portion of the grouted run-around drift was mined out after the test, to access a LANL CONVEX experiment and the drift side of the LLNL Liner Add-on. Careful hand excavation brought out the PVC pipes with the 3 corner bolt load washer pig tails (Figure 7-13) and uncovered the back of all the bolts (Figure 7-14). On August 5, the remaining loads were read from the 3 corner bolts load washers. The comparison with readings on April 16 and the remaining load percentages are:

Corner Bolt

Upper right Lower right

Lower left

\section{$\underline{4 / 16 / 92}$}

$38,250 \mathrm{lbs}$

$39,900 \mathrm{lbs}$

$40,110 \mathrm{lbs}$ $\underline{8 / 5 / 92}$

$33,800 \mathrm{lbs}$

$34,450 \mathrm{lbs}$

$35,260 \mathrm{lbs}$
Percent tension retained

$88 \%$

$86 \%$

$88 \%$

These numbers are precisely within the range of $84 \%$ to $91 \%$ estimated from SANDUS, for the upper left strain gaged bolt. 


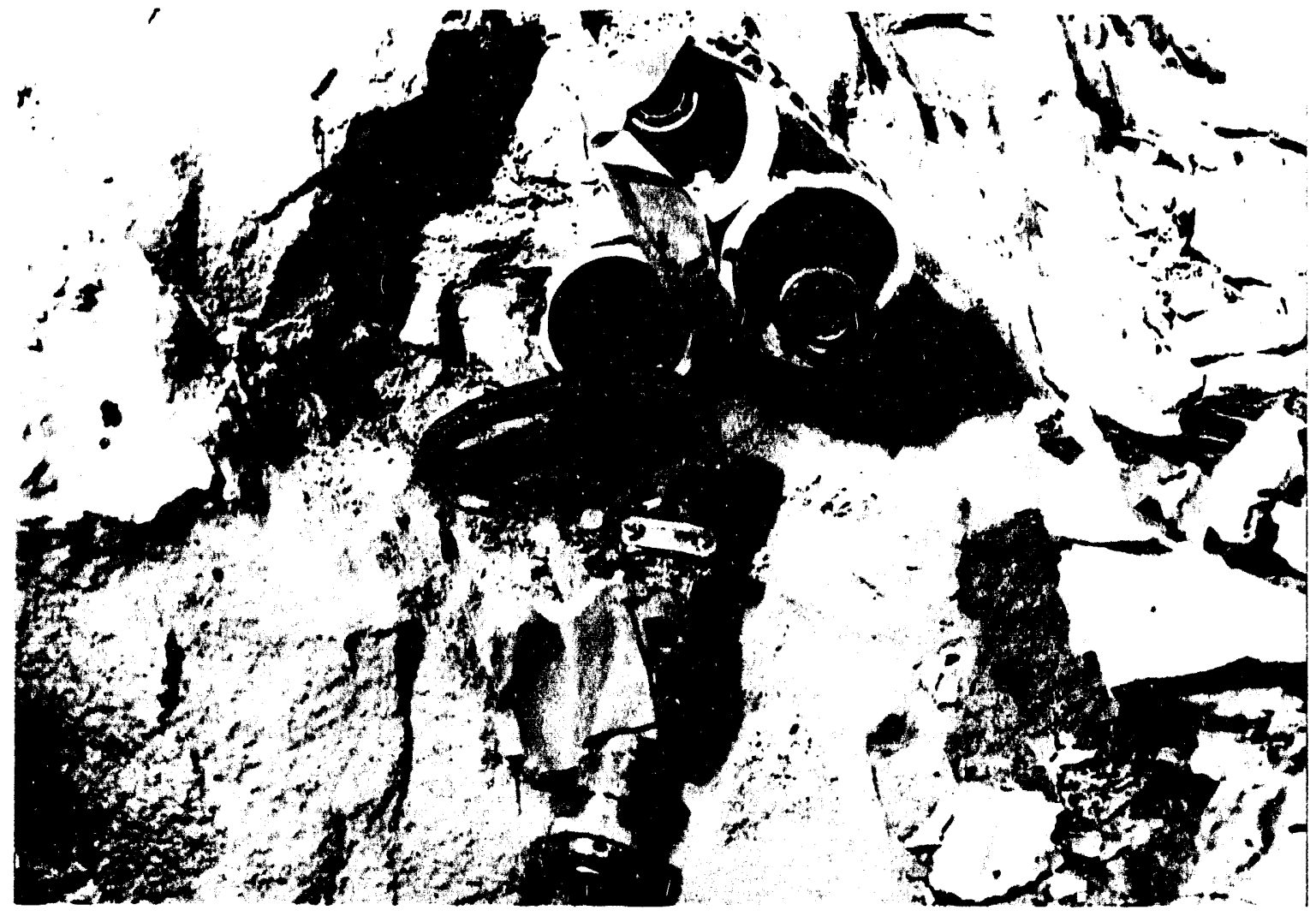

Figure 7-13: 3 corner bolt load washer pigtails excavated-out and read at re-entry.

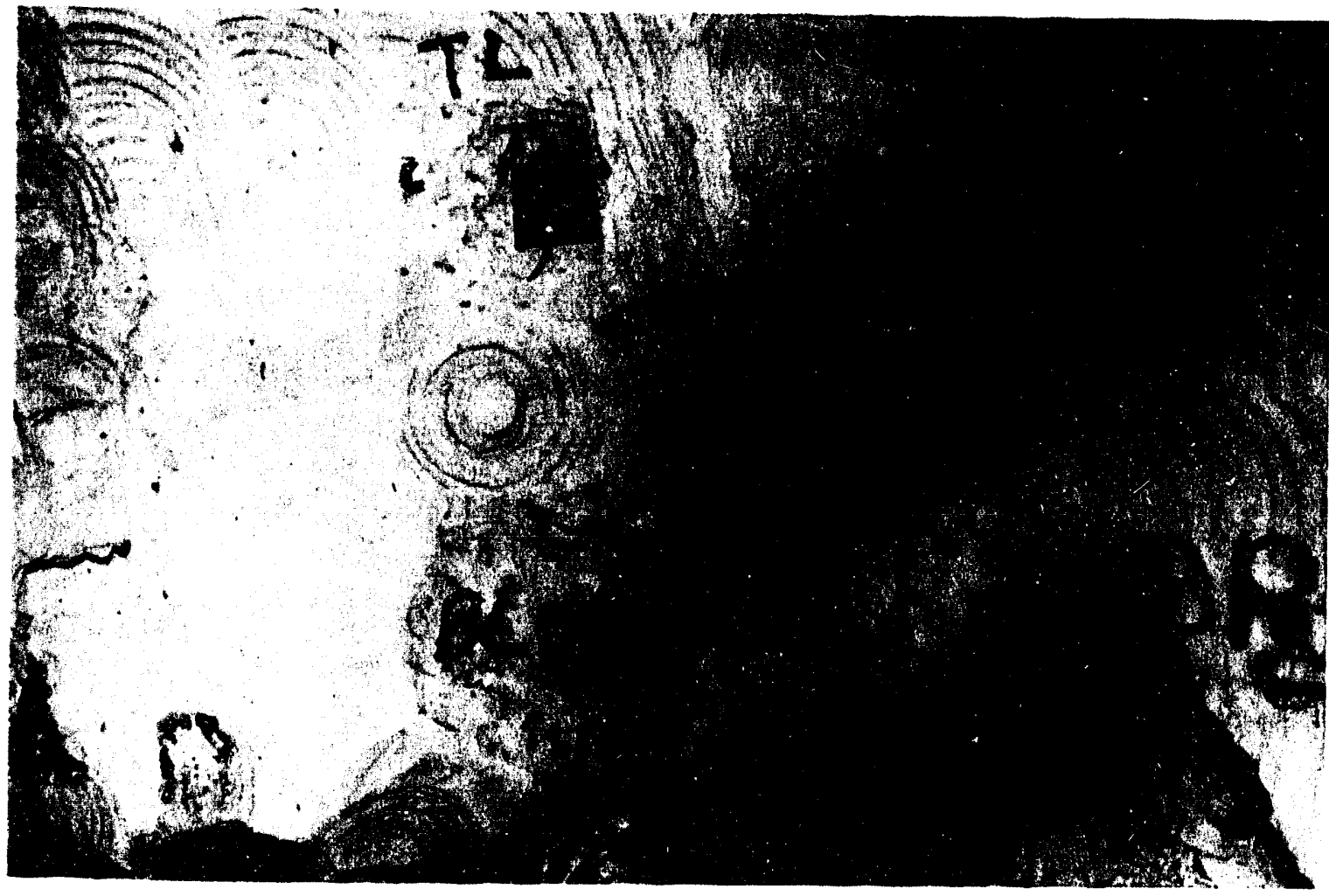

Figure 7-14: Re-entry to drift side of liner add-on. 


\section{SECTION 8}

\section{COMPARISON OF TEST DATA AND CALCULATIONS}

\subsection{MECHANICAL RESPONSE}

The dynamic response calculations performed for comparison with experimental data were carried out to $40 \mathrm{~ms}$ and used the soft model discussed in Section 6.

Comparisons of the calculated axial strain with data for the centerbolt at $x=4.89 \mathrm{~m}$ and the cornerbolt at $x=4.3 \mathrm{~m}$ are shown in Figures 8-1 and 8-2, respectively. The calculated responses for both bolts show the main features observed in the data, but have higher amplitudes. The oscillations calculated for the nearly unconstrained centerbolt are of higher amplitude than the data, and are less attenuated. The calculated response for the grout-constrained cornerbolt shows frequency behavior similar to the data but much less residual bolt tension. The data indicate a coupling influence of the bolt grouted in the borehole, i.e., the main part of the wave arrives with the wave speed of the rock. The small amplitude precursor preceding the main pulse represents some energy in the loading pulse transmitted solely by the bolt. The calculation captures this feature to some degree with the partially constrained slide surface using a coefficient of friction of 1.9. Also, considerable plastic yielding of the bolt just behind the main plate was indicated by the strain gauge at this location. Unfortunately, replicating diagnostics for the cornerbolt were not available in this experiment, but should be considered for future work.

The results in Section 6-4 showed the influence of rock compliance, strength, and compaction, along with slide-surface interface treatment on the load carrying character of the bolts. The fact that the calculated strain amplitudes for the center and corner bolts are higher than measured indicates that the combination of these properties used is not of the right mixture. Other factors could be partially responsible, such as the uncertainty associated with the blast wave loading, the assumption of rock pillar homogeneity used in the simulation, and the coarse zoning of the rock in the pillar. 


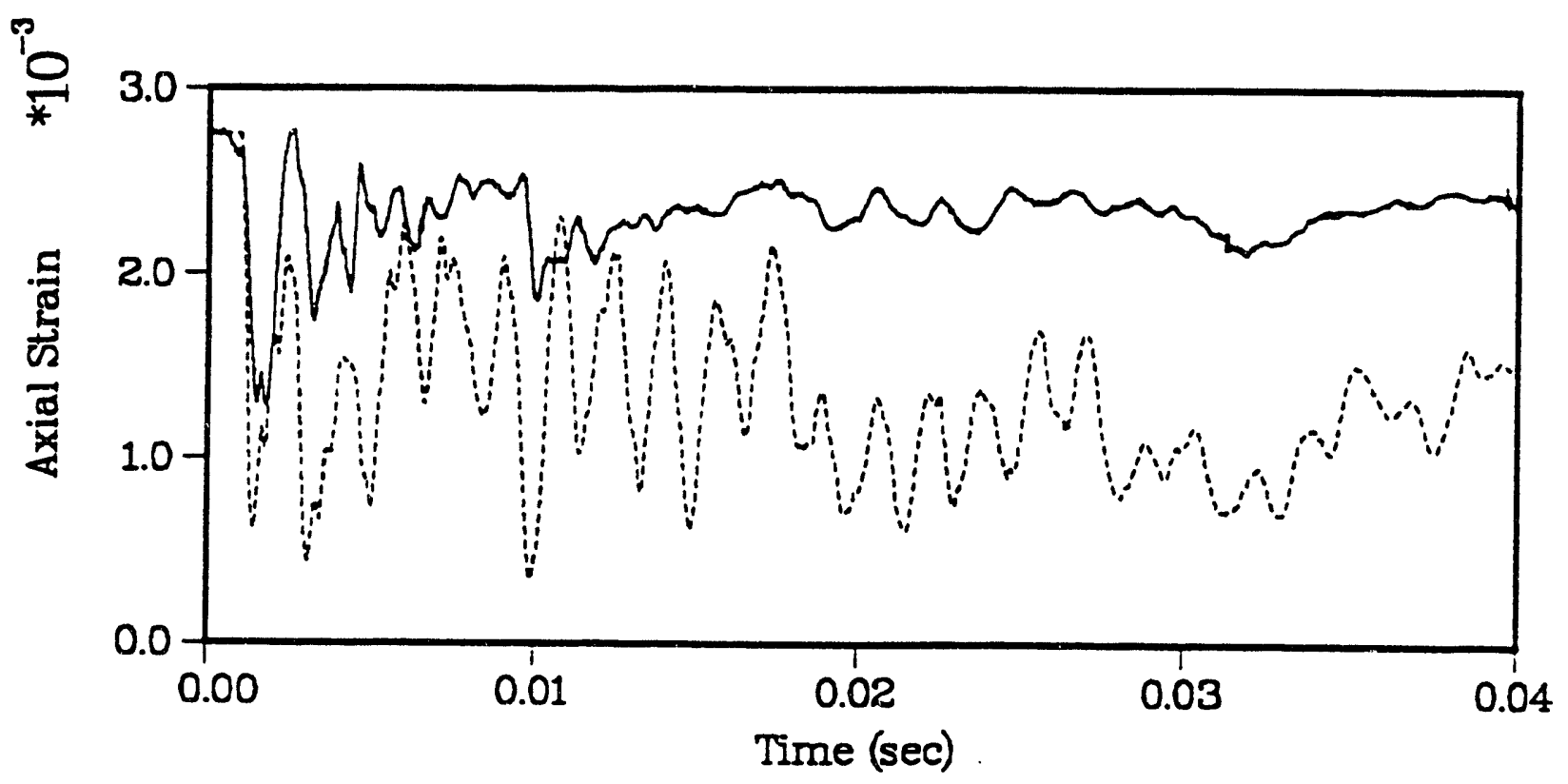

Figure 8-1: Comparison of measured axial strain in centerbolt at $x=4.89 \mathrm{~m}$ (solid curve), with calculation (dash curve).

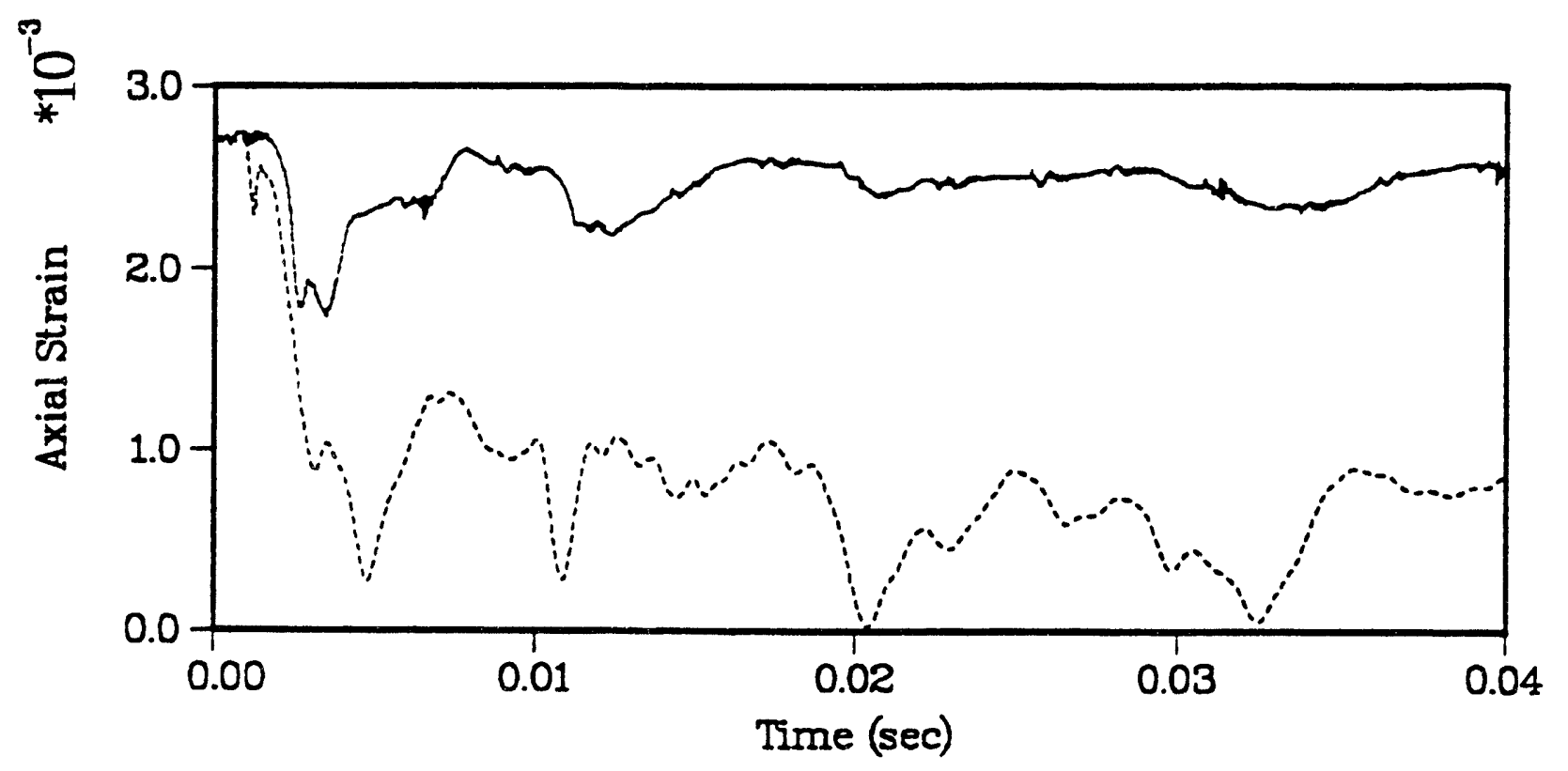

Figure 8-2: Comparison of measured axial strain in cornerbolt at $x=4.3 \mathrm{~m}$ (solid curve), with calculation (dash curve). 
Figures 8-3 and 8-4 show comparisons of the measured horizontal (y-strain) and vertical ( $z$-strain), respectively, with calculated strains located at mid-elevation on the rear of the plate and offset $0.3556 \mathrm{~m}$ from the centerbolt. Here, the calculated response captures the features observed in the data in both the amplitude and the frequency domains. The calculated response shows slightly more residual strain at late time than the data, which again is an indication that the grout or rock was modeled as too soft. Nevertheless, the agreement attained is quite good when considering other uncertainties, such as, the complex character of the cavity wall loading pulse and the assumption of symmetic quadrant loading imposed in the calculation.

The response of one of the toadstool stress gauges is compared to the calculated normal stress behind the plate in Figure 8-5. As expected, the overall agreement is good, because much of the content of the toadstool data was used to construct the loading function. The initial peak amplitude and the structure just behind the initial peak is slightly lower than the data. Again this is an indication that the grout behind the plate may have been modeled as too compliant, or that some reinforcing phenomena associated with the true cavity wall loading occurred at the elevation of the toadstool gauges. Nevertheless, the excellent representation given above by the calculation is indicative that the main features of the pressure loading on the plate are well characterized.

The calculated accelerations, behind the plate and in the rock pillar, are compared to data in Figures 8-6 and 8-7, respectively. The main features of the response behind the plate are present in the calculations; however, the calculated frequency content is slightly low. The sampling rate used in the calculations may have been too coarse. The frequency content for the calculated acceleration in the mid-portion of the pillar is similar to the data, and the peak amplitude behind the initial arrival of the pulse is in good agreement with the data; but the continuing high amplitude reverberations are not representative of the data. These reverberations are felt to be due to the coarseness of the zoning used in the rock causing prematuie elastic response in the rock pillar that is not able to be damped. Although about 25,000 elements were used, the resolution in the midpillar region was sacrificed to allow finer zoning at the cavity face and in the rear. 


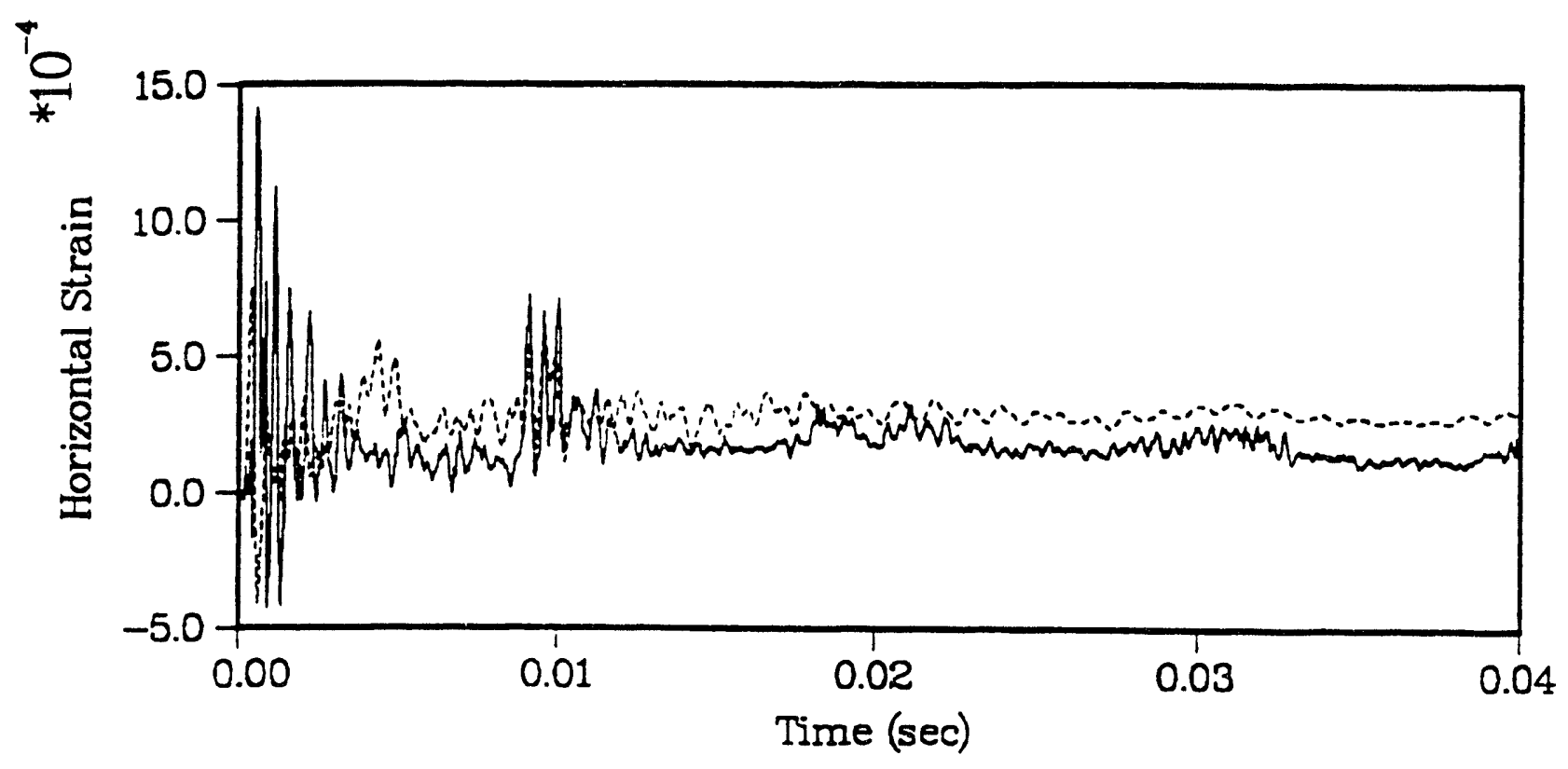

Figure 8-3: Comparison of measured horizontal strain on back of plate (solid curve), with calculation (dash curve).

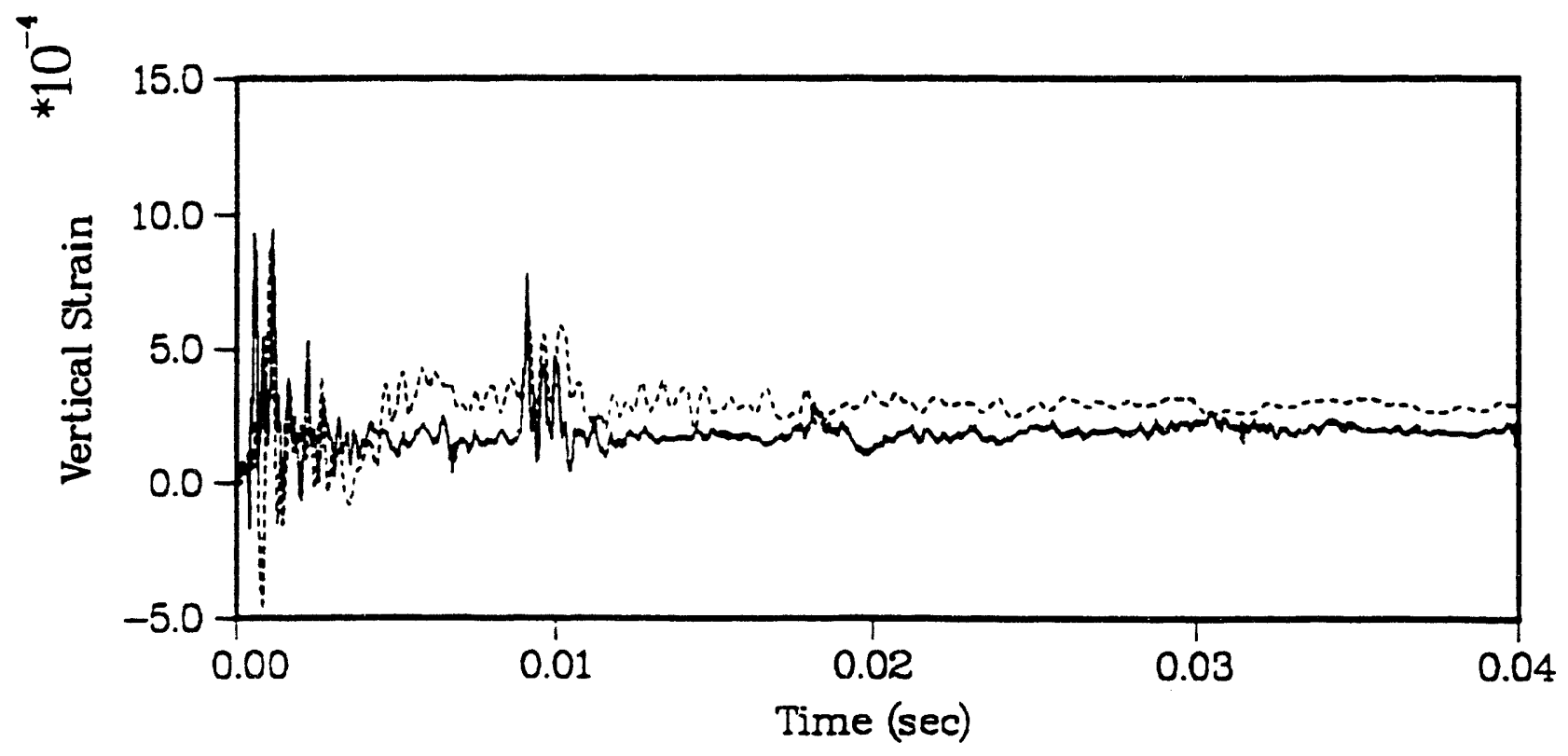

Figure 8-4: Comparison of measured vertical strain on back of plate (solid curve), with calculation (dash curve). 


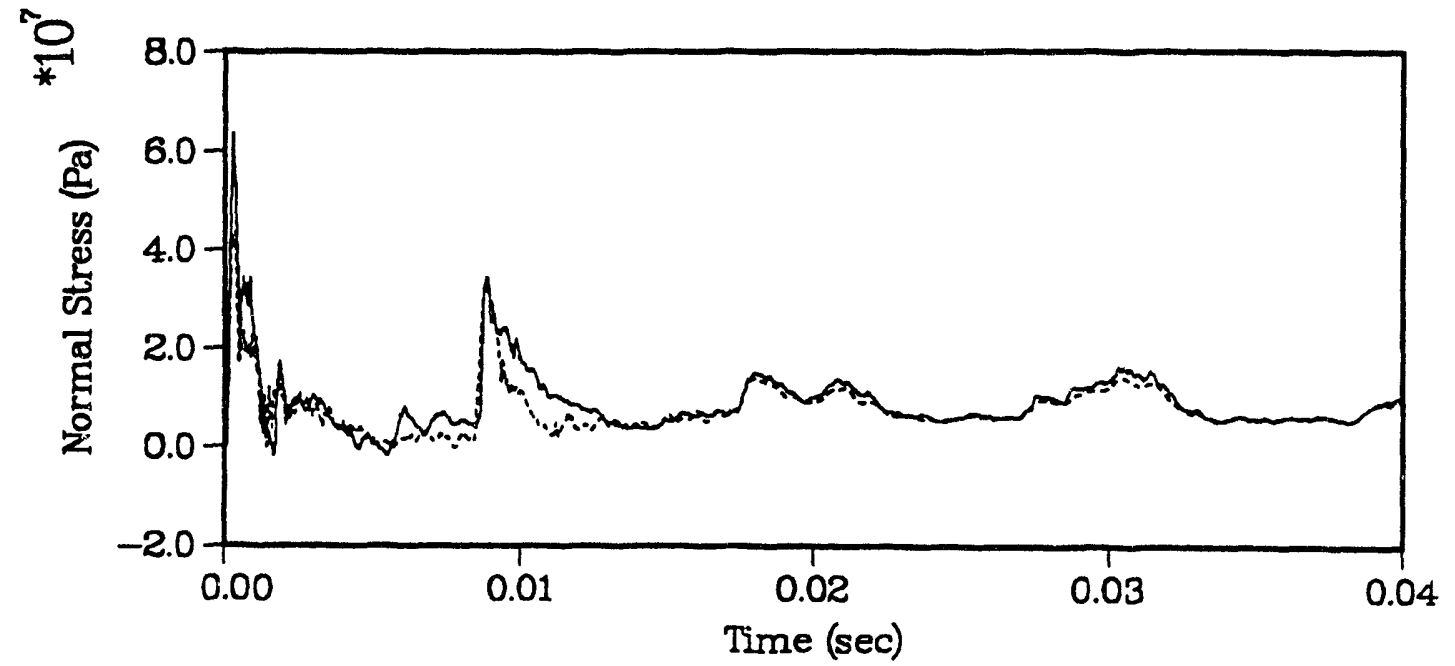

Figure 8-j: Comparison of normal stress behind plate measured by toadstool (solid curve), with calculation (dash curve).

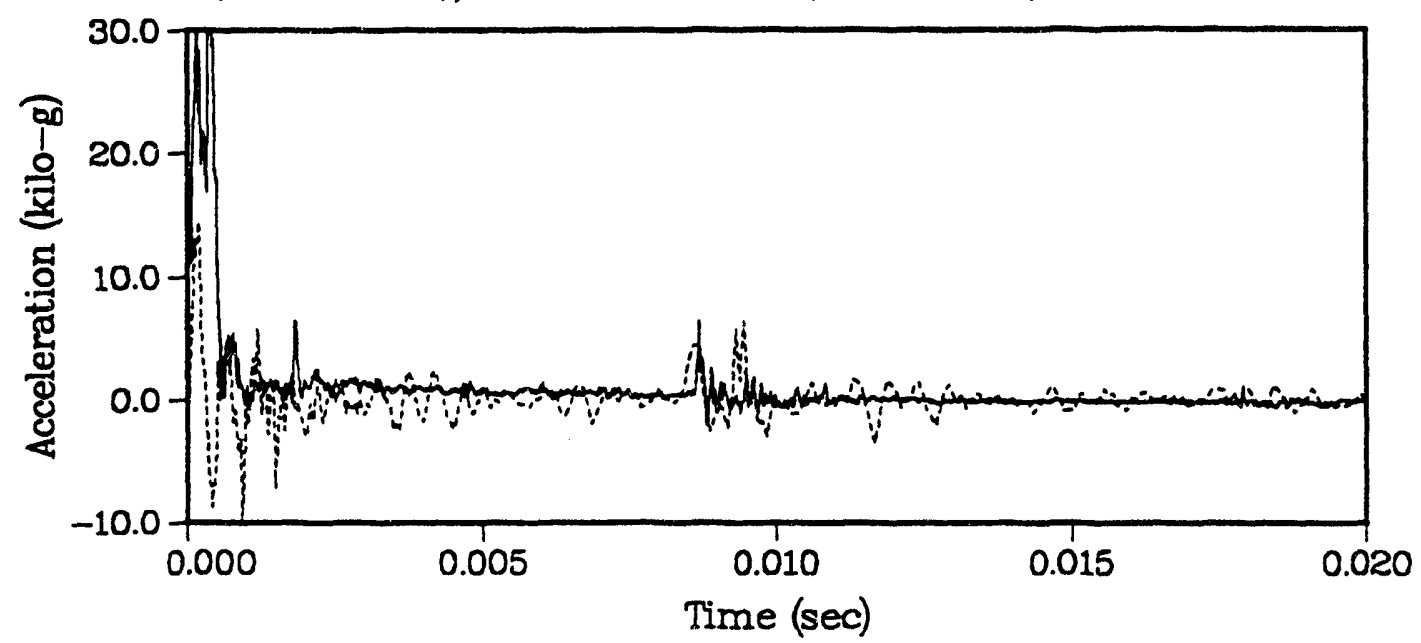

Figure 8-6: Comparison of measured acceleration on back of plate (solid curve), with calculation (dash curve).

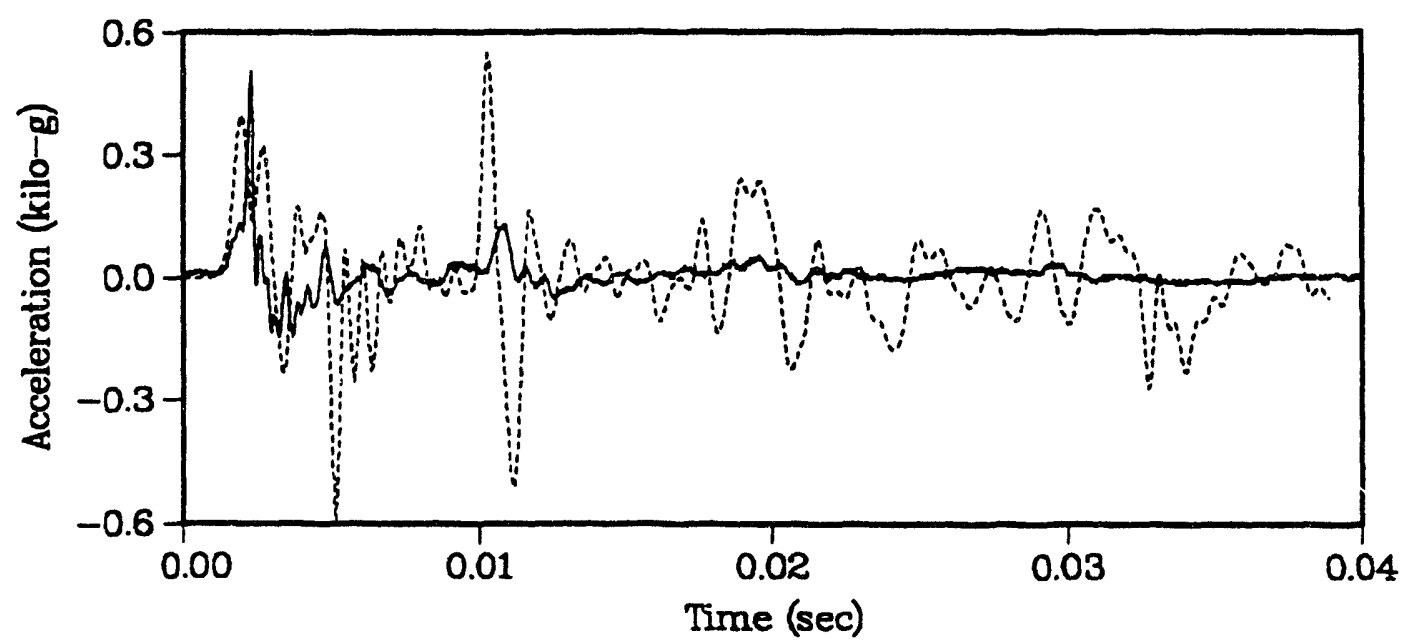

Figure 8-7: Comparison of measured acceleration in pillar (solid curve), with calculation (dash curve). 


\subsection{THERMAL RESPONSE}

As shown in Figure 8-8, the measured temperature on the back of the plate (curve $D$ ) falls within the range estimated for that location (curve $B$ ) and the temperature $2.5 \mathrm{~cm}$ away, in the grout (curve C). Clearly, the temperature gradients are very high and the temperature history extremely sensitive to position.

Considering the simplifying assumptions made for the modeling, the predictions appear to be quite satisfactory. Further refinements would include using temperature-dependent thermal properties of the grout, and attempting to account for the vaporization of moisture behind the plate.

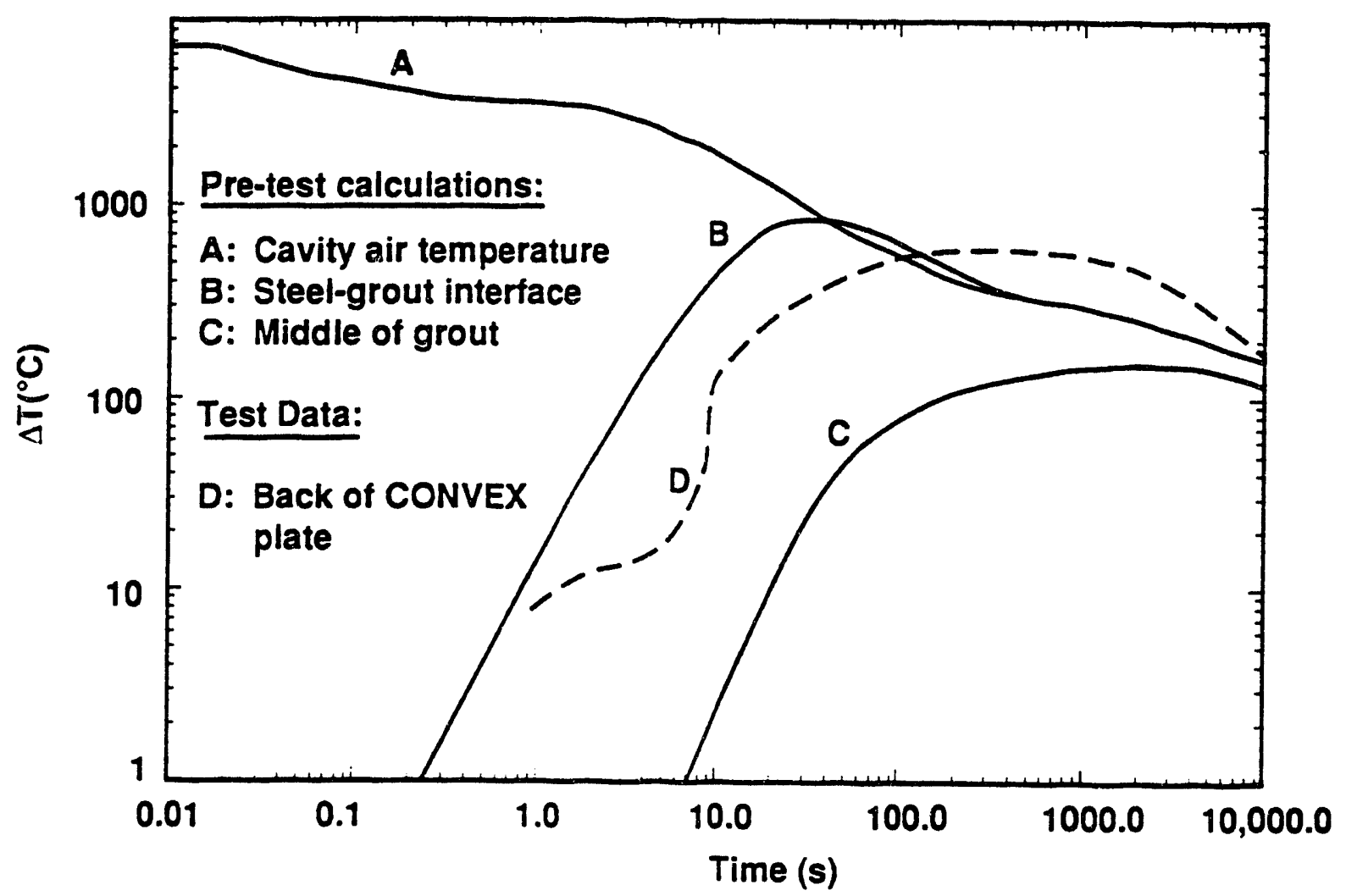

Figure 8-8: Comparison of measured and predicted temperature on the back of the plate. 


\section{SECTION 9}

\section{SUMMARY AND CONCLUSIONS}

This experiment was a proof-of-concept test for the proposed steel-lined rock cavity design, to be used as a CONVEX reusable nuclear test bed. The main structural requirements for such a facility would be to survive the loadings, and to be serviceable. Specifically, it would require that the liner stay stressed on the rock at all times and that any reduction in pre-tension be adjustable. The experiment had a field component, to obtain data on a real liner under an actual nuclear loading, and a modeiing component to better understand the data and to extrapolate the results to other situations, based on validated models.

The modeling exhibited some strengths and some weaknesses. In particular, the rock models used did not provide the energy dissipation actually observed, and the bolt tensioning and grouting sequence was only approximated. On the other hand, the 3-dimensional numerical models clearly could be refined to give an even more accurate match to the observations, therefore validating them for future CONVEX type studies.

The main operational objectives of this project were to acquire response data of the system under nuclear loading and to ascertain the status of contact between the steel plate and the rock, as shown by toadstool data and bolt tension data.

The instrumentation and data acquisition system performed extremely well. Mechanical and thermal data were recorded during the dynamic phase; plate temperature was monitored for several hours after the test; and the remaining tension was obtained for several bolts more than three months after the test, upon re-entry in the run-around drift. The test results indicated that the operational objectives had been met and that the concept of a steel-lined rock cavity could provide for reusable test beds for repeated low yield nuclear events. 


\section{SECTION 10}

\section{REFERENCES}

1. Glenn, L. A., and Kidder, R. E., (1982), "Blast Loading of a Spherical Container Surrounded by an Infinite Elastic Medium", Lawrence Livermore National Laboratory, UCRL-88280, Oct., 18p.

2. Glenn, L. A., and Young, D. A., (1982), "Blast Attenuation in a Shot Tunnel Using Water Jets", Lawrence Livermore National Laboratory, UCID-19419, July, $43 \mathrm{p}$.

3. Heuze, F.E., (1983) "Preliminary Structural Investigations for a High-Energy Density Facility", Lawrence Livermore National Laboratory, UCID-19575Rev. 1 June, $37 \mathrm{p}$.

4. Heuze, F.E., and Thorpe, R.K., (1983) "Geological Engineering Considerations for a High Energy Facility, and a Cost Estimate for the Related Conceptual Design", Lawrence Livermore National Laboratory, UCID-19848, July, 40 p.

5. Kipp, T.R., and Kennedy, R.P., (1978) "Cost and Feasibility Evaluation for the Excavation of Large Hemispherical Cavities in Rainier Mesa", DNA 4723T, October.

6. Glenn, L.A. and Young, D.A., (1982) "Blast Attenuation in a Shot Tunnel Using Water Jets", Lawrence Livermore National Laboratory, UCID-19419

7. Thorpe, R.K., and Heuze, F.E., (1985) "Dynamic Response of Rock Reinforcement in a Cavity Under Internal Blast Loading: An Add-on to the Pre-MILLYARD Event", Lawrence Livermore National Laboratory, UCID$\underline{20604}$ Sept., 36 p.

8. Thorpe, R.K., and Heuze, F.E., (1986) "Preliminary Studies of Reinforcement Dynamics for a Reusable Underground Test Chamber", Proc. 27th U.S. Symp. on Rock Mechanics, Tuscaloosa, AL, June, pp 801-807 (Soc. Mining Eng., Littleton, $\mathrm{CO}$ )

9. Goodman, R.E., (1976) "Methods of Geological Engineering" (West Publishing, New York), $472 \mathrm{p}$.

10. Deere, D.U., and Deere, D.W., (1989) "Rock Quality Designation (RQD) After Twenty Years", Report GL-89-1, U.S. Army Waterways Experiments Station, Vicksburg, Miss, Feb., 
11. Goodman, R.E., Van, T.K., and Heuze, F.E., (1970) "Measurement of Rock Deformability in Boreholes", Proc. 10th U.S. Symp. Rock Mech. Austin, TX, pp 523-555 (Soc. Min. Eng., Littleton, CO)

12. Heuze, F.E., and Amadei, B., (1985) "The NX-Borehole Jack: A Lesson in Trials and Errors", Int. I. Rock Mech. Mining Sci. v. 22, n.2, pp 105-112

13. Heuze, F.E., (1980) "Scale Effects in the Determination of Rock Mass Strength and Deformability", Rock Mechanics, v. 12, pp 167-192

14. Shapiro, A.B., (1986) "TOPAZ 2D - A Two-Dimensional Finite Element Code for Heat Transfer Analysis, Electrostatic, and Magnetostatic Problems", Lawrence Livermore National Laboratory, UCID-20824, 110 p., July

15. Metals and Ceramics Information Center (1990) "Structural Alloys Handbook: A 36 Steel", v. 3, pp 1-17, (Battelle, Columbus, $\mathrm{OH}$ )

16. Metals and Ceramics Information Center (1990) "Structural Alloys Handbook: Medium Carbon Steels", v. 1, pp 2-62, (Battelle, Columbus, OH)

17. Lindroth, D.P., and Krause, W.G. (1971) "Heat Content and Specific Heat of Six Rock Types at Temperatures to $1000^{\circ} \mathrm{C}^{\prime \prime}$, U.S. Bureau of Mines, RI 7503, $24 \mathrm{p}$.

18. Lindroth, D.P., (1974) "Thermal Diffusivity of Six Igneous Rocks at Elevated Temperatures and Reduced Pressures", U.S. Bureau of Mines, RI 7954, 33 p.

19. Richter, D., and Simmons, G., (1974) "Thermal Expansion Behavior of Igneous Rocks", Int. I. Rock Mech. Mining Sci. v. 11, pp 403-411

20. Harley, E.J., Dewitt, D.F., and Roy, R.F., (1978) "The Thermal Diffusivity of Eight Well Characterized Rocks for the Temperature Range 300-1000 K", Engineering Geology v. 12, pp 31-47

21. Durham, W.B., Mirkovich, V.V., and Heard, H.C., (1987) "Thermal Diffusivity of Igneous Rocks at Elevated Temperature and Pressure", I. Geophys. Res. v. 92, n. B11, pp 11, 615-11, 634, Oct. 10.

22. Zimmerman, R.M., (1982) "Conceptual Design of Field Experiments for Welded Tuff Rock Mechanics Program", Sandia National Laboratories, Albuquerque, NM, SAND 81-1768, Oct.

23. Moss, M., Koski, J.A., Haseman, G.M., and Torney, T.V., (1982) "The Effect of Composition, Porosity, Bedding Plane Orientation, Water Content, and a Joint, on the Thermal Conductivity of Tuff", Sandia National Laboratories, Albuquerque, SAND 82-1164, 28 p., Nov. 
24. Levatin, J. L., Attia, A. V., and Hallquist, J. O., (1990), "KDYNA User's Manual", Lawrence Livermore National Laboratory, UCRL-ID-106104 168 p., Sept.

25. Maker, B. N., Ferencz, R. M., and Hallquist, J. O., (1991), "NIKE3D - A Nonlinear, Implicit, Three-Dimensional Finite Element Code for Solid and Structural Mechanics- User's Manual", Lawrence Livermore National Laboratory, UCRL-MA-105268, Jan.

26. Whirley, R. G., and Hallquis". J. O., (1991), "DYNA3D - A Nonlinear, Explicit, Three-Dimensional Finite Element Code for Solid and Structural Mechanics - User's Manual", Lawrence Livermore National Laboratory, UCRL-MA-107254, 314 p., May. 


\section{SECTION 11}

\section{ACKNOWLEDGMENTS}

The success of this experiment is due to the coordinated efforts of a large team of people to whom we are thankful:

- at LLNL, R. Fortner and A. Toor for their programmatic support; B. Engleman, B. Maker, A. Shapiro, and R. Whirley for their advice on computations; W. Lin for mechanical tests on rock and grout; P. Proctor for graphics; V. Peterson and S. Uhlhorn for their skillful typing of the manuscript; and R. Shaffer for his editorial review of the report.

- at SNLA, T. Bergstresser, S. Breeze, A. Chabai, C. Kinabrew, G. Miller, and R. Vasquez for their work on instrumentation; T. Steinfort for the construction phase of the project; T. Hendrickson and the late M. Bakos for data acquisition; L. Carillo, J. Patrick, and R. Tillery for bolt tensioning; A. Beattie and J. Sena for microseismic monitoring during bolt tensioning; J. Metcalf for radiation safety during re-entry; and J. Plimpton for editorial review.

- at RSN, K. Schulenburg for engineering support; and V. Thummala for load cell calibration.

- at EGG, G. DeMille as cable coordinator; and E. Vieth for his work on gages.

- at REECO, L. Arnold for some of the photography.

- at LANL, C. Snell for estimates of cavity pressure history.

- at DNA, D. Linger, for his support of the project; and R. Jackson, J. La Comb, R. Price, D. Reidenbach, and F. Roessler for their operational contributions.

This project was supported by funding from the three DOE Laboratories and by the contribution in-kind from DNA, to reduce construction and re-entry costs for the experiments. 
.
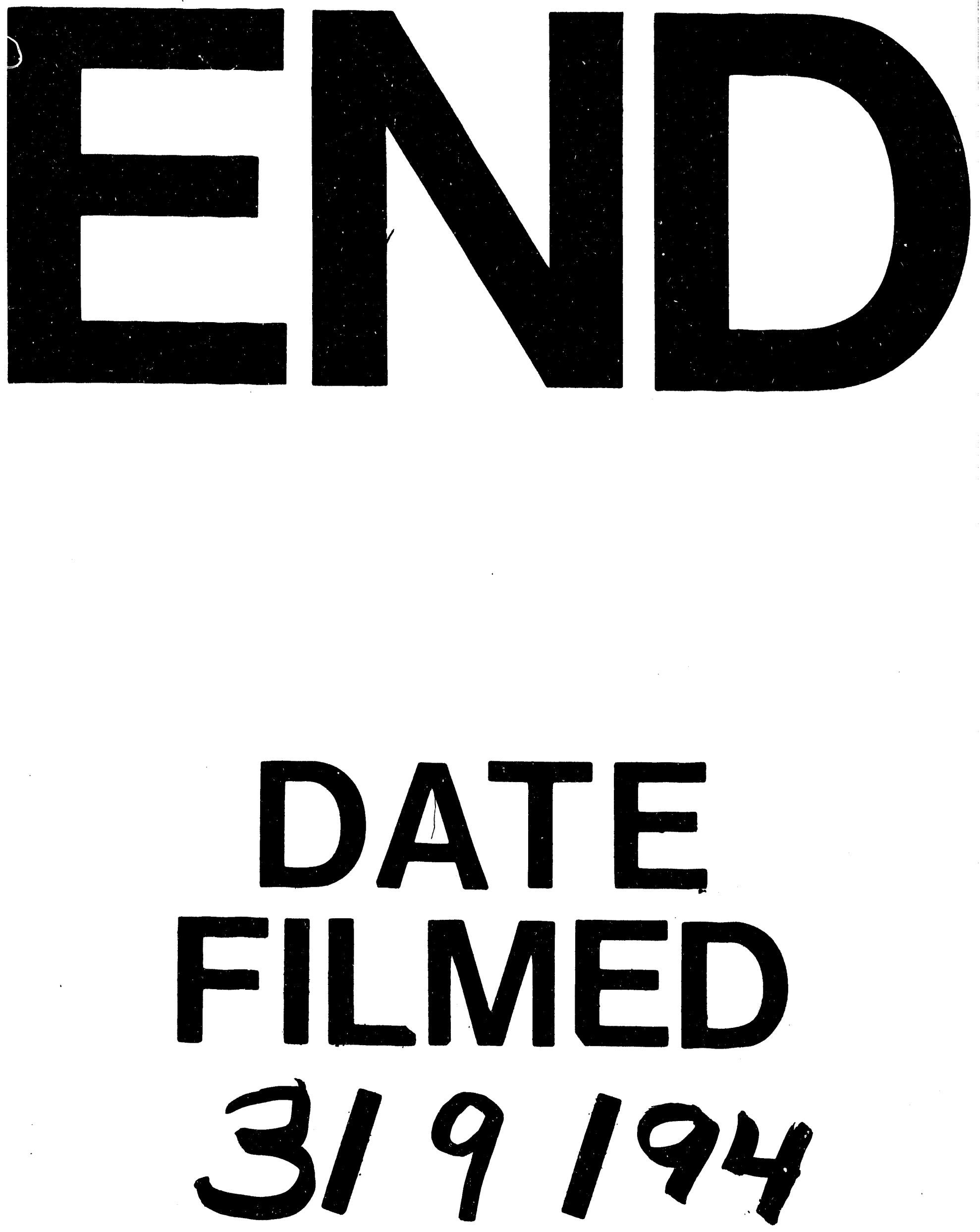

1 


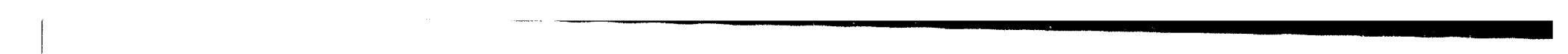

